\title{
Who Is A "TERRORIST"? DRAWING THE LINE BETWEEN CRIMINAL DEFENDANTS AND MILITARY ENEMIES
}

\author{
Benjamin J. Priester ${ }^{*}$ \\ TABLE OF CONTENTS
}

I. INTRODUCTION 1255

II. LIABILITY UNDER U.S. FEDERAL CRIMINAL LAW ......................................1257

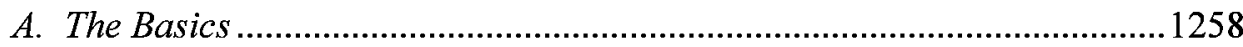

1. Direct Liability (Personal Participation) .............................................1258

2. Inchoate Offense Liability (Conspiracy \& Attempt) ...............................1260

3. Vicarious Liability (Conspiracy \& Complicity) ......................................1262

4. Facilitation Liability (Material Support) ……………........................1265

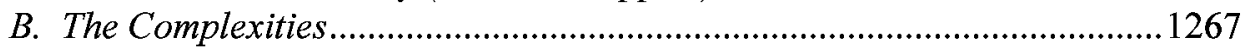

III. APPLICABILITY OF THE INTERNATIONAL LAWS OF WAR.............................1276

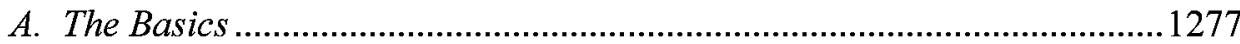

1. Combatants, Noncombatants, and War Criminals .............................1279

2. International Armed Conflicts ............................................................1283

3. Noninternational Armed Conflicts ....................................................1290

4. The Bush Administration and the Military Commissions Act

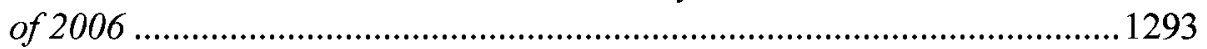

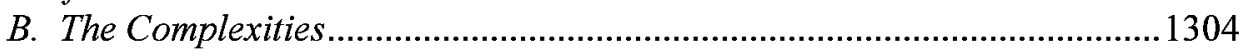

IV. DEFINING THE TERRORIST THREAT: INTEGRATING THE TWO MODELS .......1315

A. Prevention and Punishment Objectives ..............................................1315

B. Insights and Shortcomings ..............................................................1318

C. Balancing the Significance of Personal Conduct

and Group Affiliation

D. Consequences: Military Enemies and Criminal Defendants .....................1325

E. Other Implications of the Integrated Model .........................................1334

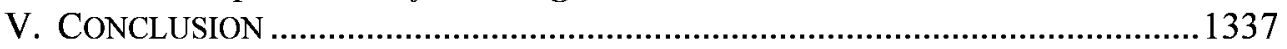

\section{INTRODUCTION}

The threat of terrorist attacks by al Qaeda and other transnational terrorist organizations is a constant topic of public discourse in the United States. Despite its prominence, the nature of that threat is notoriously difficult to define. On the one hand, terrorists might be compared to other kinds of organized, dangerous criminals who should be prosecuted and punished using the federal criminal law.

*(C) 2008 Benjamin J. Priester, Associate Professor, Florida Coastal School of Law. I am grateful to Curtis Bridgeman, Brian Galle, Wayne Logan, Dan Markel, Lesley Wexler, and the participants in Florida State University College of Law's faculty enrichment workshop for their comments, insights, and suggestions. 
On the other hand, terrorists might be compared to enemy soldiers engaged in warfare against the United States. There are problems with either approach, however, because the threat posed by al Qaeda and other transnational terrorist organizations is substantially different from both paradigmatic criminal activity and paradigmatic military conflict. Accordingly, it is far from clear whether alleged terrorists should be treated as criminal defendants or military enemies.

The definitional problem is made even more complicated by the reality that the terrorist threat has many components. The organization itself, such as al Qaeda, is a danger. So too are the leaders, commanders, and strategists who plan and manage plots to carry out terrorist attacks, and the operatives and agents who commit or try to commit them.

Many other individuals play roles in terrorist activity, as well. Some individuals may assist in the preparations for an attack by providing weapons, bombs, information, or surveillance. Other individuals might provide safe houses, transportation, or financing to those involved in a planned attack, but have no direct role in the actual anticipated violence. Finally, some individuals may support the overall objectives of the terrorist group with money or other general resources, yet have no personal involvement in, or even knowledge of, any particular plan to carry out specific terrorist acts.

Are all of these individuals "terrorists" because of their involvement, at some level, in the activities of al Qaeda or another transnational terrorist organization? Are only some of them "terrorists" and others not, and potentially subject to differential treatment based on their level of participation? Most importantly, which of these individuals are properly deemed military enemies subject to military authority, including identification as targets of military force, detention as military prisoners, and prosecution in military proceedings? Likewise, which of these individuals must be deemed criminal defendants subject to prosecution and punishment under criminal law in civilian courts?

The U.S. federal criminal law and the international laws of war provide alternative models for answering these difficult questions. The criminal model presents one framework for defining the threat of terrorism, primarily focused on the prosecution and punishment of individuals for their alleged terrorist activities. The military model offers another framework, emphasizing the dangers posed by an organized armed force engaged in planning and carrying out acts of war. Each model provides options for pursuing the dual objectives of preventing terrorist attacks from occurring and punishing individuals involved terrorism, whether one plans or commits acts of terrorism or supports the operations of terrorist organizations. Yet in their currently existing forms, neither model is adequate to fully address the nature of the threat posed by al Qaeda and other transnational terrorist organizations.

The criminal and military models each provide insights into the nature of the terrorist threat, identifying particular aspects of the problem that most closely resemble their respective paradigms. Each model also has shortcomings in defining the threat. Both models struggle to balance the relative importance of personal conduct and group affiliation, assessing the dangerousness and culpability of 
individual terrorists and the broader organizations of which they are a part. Thus, neither model, standing alone, adequately addresses all aspects of the problem.

The solution is to combine the criminal and military models into an integrated model for defining the threat of al Qaeda and other transnational terrorist organizations. This new model identifies which individuals with involvement in or connections to terrorists should be treated as criminal defendants and which individuals should be deemed military enemies subject to military authority. In doing so, this integrated model pursues the dual objectives of prevention and punishment by using the insights of the criminal and military models to compensate for their respective shortcomings. It balances the importance of personal conduct and group affiliation by reserving the most substantial consequences for activities dependent on direct, personal involvement. An integrated model also can fully account for the particular dangers that exist because al Qaeda is a form of organized armed force, and the substantial implications that fact holds for the nature of the terrorist threat. This integrated model concludes that most individuals involved in terrorism should be treated as criminal defendants, and that only the most dangerous direct participants should be deemed military enemies. Through this analysis, the integrated model resolves the problems with the existing criminal and military models and fully addresses the threat posed by al Qaeda and other transnational terrorist organizations.

\section{LIABILITY UNDER U.S. FEDERAL CRIMINAL LAW}

One model for addressing the terrorist threat is prosecution under U.S. federal criminal law. The applicable offenses and forms of liability create an extensive array of available charges against individuals involved to widely varying extents in terrorist activities. Federal criminal law punishes persons who directly participate in carrying out acts of terrorist violence, of course, but it reaches far deeper into terrorist networks than that. It also punishes those who plan, organize, or direct specific terrorist operations and those who provide assistance and resources for particular terrorist plots. In addition, some individuals have involvement with or connections to al Qaeda or another transnational terrorist organization without participating in, or even being aware of, any specific scheme to carry out a particular act of terrorism. In many circumstances, federal criminal law punishes those forms of assistance and support as well. Thus, even those who render relatively minor assistance to terrorists and terrorist organizations face substantial penalties. ${ }^{1}$

${ }^{1}$ In certain situations, the application of U.S. federal criminal authority to accused terrorists would raise controversial questions of extraterritoriality. In most cases, however, jurisdiction is available. See generally United States v. Yousef, 327 F.3d 56, 85-111 (2d Cir. 2003) (discussing various forms of extraterritorial jurisdiction and rejecting defendant's jurisdictional challenge). For example, no extraterritorial jurisdiction is needed when the defendant's own activities occurred within the United States; whether the 


\section{A. The Basics}

Federal criminal law provides four forms of liability for participation in terrorism, encompassing varying degrees of involvement in terrorist plots and organizations. Most obviously, charges may be filed against individuals who personally took part in a completed act of terrorism. Those charges, however, may not consist entirely, or even partly, of crimes specifically designed for punishing terrorism. Instead, generally applicable offenses, which happen to fit the facts, often are charged in terrorism cases. Additionally, inchoate offenses may be filed in connection with personal involvement in a foiled, unsuccessful, or planned, but not yet implemented, terrorist plot.

Even more broadly, liability extends far beyond direct personal participation in terrorist violence. Under federal conspiracy law, a member of a conspiratorial agreement will be convicted of the crimes committed by other conspirators. This liability extends to crimes in which he had no personal involvement, and even offenses he did not specifically conspire to commit.

Finally, individuals who do not participate in violent crimes or conspiracies may be charged with crimes of facilitating terrorism if they render support to the general objectives of terrorist organizations. Unlike the other forms of liability, however, such charges do not impose liability for the crimes directly related to the actual or contemplated terrorist acts. Rather, under the "material support" offenses, persons who knowingly render aid toward terrorist objectives are guilty of a separate, but still serious, felony.

\section{Direct Liability (Personal Participation)}

The first form of liability under U.S. federal criminal law includes charges arising from direct personal participation in completed crimes of terrorist activity. For example, the men who carried out the first World Trade Center attack in 1993

contemplated terrorist attack was to (or actually did) take place in the United States or in a foreign country is irrelevant. See, e.g., United States v. Salameh, 152 F.3d 88, 107-08 (2d Cir. 1998) (involving a conspiracy abroad to commit the 1993 World Trade Center bombing in the U.S.); United States v. Sattar, 314 F. Supp. 2d 279, $285-93$ (S.D.N.Y. 2004) (involving a conspiracy in the U.S. to commit terrorist attacks abroad, including an attack in Luxor, Egypt). Extraterritorial jurisdiction also is readily available for crimes committed abroad when the target (or victim) of the attack is the United States or its government. See, e.g., Yousef, 327 F.3d at 80-85 (involving a foiled 1995 al Qaeda plot to bomb U.S. airliners while in flight over the Pacific Ocean); United States v. Bin Laden, 92 F. Supp. 2d 225, 227-31 (S.D.N.Y. 2000) (involving 1998 al Qaeda bombings of two U.S. embassies in Africa). And it is available for crimes committed abroad when the defendant is a U.S. citizen. See, e.g., First Superseding Indictment, United States v. Gadahn, Criminal No. 05-254(A) (C.D. Cal. Oct. 11, 2006), available at http://www.usdoj.gov /opa/documents/adam_indictment.pdf [hereinafter Gadahn Indictment] (indicting fugitive U.S. citizen for treason and material support for terrorism based on conduct abroad). 
were convicted of the bombing. ${ }^{2}$ Individuals involved in the bombings of two U.S. embassies in Africa in 1998 also were charged criminally and convicted. ${ }^{3}$ And a U.S. citizen is currently under indictment for treason for his actions in inciting terrorist violence against the United States. ${ }^{4}$

Some charges of this type are specifically designed for prosecuting terrorists. One offense applies to the killing of a U.S. national when it "was intended to coerce, intimidate, or retaliate against a government or a civilian population." Another offense punishes the use of weapons of mass destruction. ${ }^{6}$ A third offense in the same chapter is entitled "acts of terrorism transcending national boundaries." Aircraft piracy is another offense often viewed as a terrorism crime. ${ }^{8}$

Interestingly, many charges filed against accused terrorists involve the application of "ordinary" crimes to terrorist conduct, rather than terrorism-specific offenses. Terrorist bombings, for example, have been prosecuted under an offense proscribing destruction, by fire or explosive, of property of the United States Government and property used in interstate commerce. ${ }^{9}$ On its face that crime is unrelated to terrorism, and in fact often is prosecuted in contexts that have nothing to do with terrorism, such as ordinary arson. ${ }^{10}$ Similarly, a criminal statute sometimes used to prosecute plots to carry out terrorist attacks overseas initially was enacted to deal with a different foreign-relations problem entirely: mercenaries and soldiers of fortune. ${ }^{11}$ And perhaps most simply of all, killings committed by

${ }^{2}$ See Yousef, 327 F.3d at 135-37; Salameh, 152 F.3d at 107-08.

${ }^{3}$ See Bin Laden, 92 F. Supp. 2d at 227-31.

${ }^{4}$ See Gadahn Indictment, supra note 1, at 2-4.

5 18 U.S.C. $\$ 2332$ (2006); see Yousef, 327 F.3d at 135-37 (1993 World Trade Center bombing).

${ }^{6}$ See 18 U.S.C. $\$ 2332 \mathrm{a}$; see Bin Laden, 92 F. Supp. 2 d at 228 n. 2 (truck bombs).

718 U.S.C. $\$ 2332 \mathrm{~b}$; see Superseding Indictment at 6-7, United States v. Moussaoui, Criminal No. 01-455-A (E.D. Va. July 16, 2002), available at http://capitaldefenseweekly. com/library/moussaoui/1_01-cr -00455/ docs/ 66826/0.pdf [hereinafter Moussaoui Indictment].

${ }^{8}$ See 49 U.S.C. $§ 46502$; Moussaoui Indictment, supra note 7, at 25.

${ }^{9}$ See 18 U.S.C. $\$ 844(\mathrm{f})$, (i); see, e.g., United States v. Salameh, 152 F.3d 88, 152-53 (2d Cir. 1998) (involving the 1993 World Trade Center bombing); United States v. Bin Laden, 92 F. Supp. 2d 225, 228 n.2 (S.D.N.Y. 2000) (involving the 1998 U.S. embassy bombings); see also United States v. McVeigh, 153 F.3d 1166, 1176 (10th Cir. 1998) (affirming the defendant's conviction for blowing up a federal building); United States v. Nettles, 400 F. Supp. 2d 1084, 1086 (N.D. Ill. 2005) (affirming the defendant's conviction for "attempting to damage and destroy" a federal building).

${ }^{10}$ See, e.g., Jones v. United States, 529 U.S. 848, 850-51 (2000) (holding "that an owner-occupied residence not used for any commercial purpose does not qualify as property 'used in' commerce or commerce-affecting activity" for purposes of the statute).

${ }_{11}^{11}$ See 18 U.S.C. $\$ 956$ (conspiracy to kill, kidnap, maim, or injure persons or damage property in a foreign country); Robert M. Chesney, Beyond Conspiracy? Anticipatory Prosecution and the Challenge of Unaffiliated Terrorism, 80 S. CAL. L. REV. 425, 459 (2007) (explaining that $\S 956$ "originally was intended to protect the federal government's 
terrorists may be prosecuted under the generally applicable federal murder statutes. ${ }^{12}$

Regardless of the exact offenses charged in any given case, however, the fact remains that federal criminal law provides a wide variety of crimes that can be used to prosecute and convict individuals who directly participate in the execution of a terrorist attack.

\section{Inchoate Offense Liability (Conspiracy \& Attempt)}

Ideally, of course, terrorists will be apprehended before their plots can be carried out so that charges for a completed act of terrorism are not possible. In these circumstances, inchoate offense theories must be used to bring charges. In some situations, the defendant can be charged with attempting the relevant crimes. In other situations, conspiracy law will be used.

Oddly, the Federal Criminal Code lacks a generally applicable provision that would make the attempt to commit a federal offense itself a federal offense. ${ }^{13}$ Nevertheless, the text of some federal crimes includes attempted violations within the definition of the offense. ${ }^{14}$ Many of the offenses described above contain such language. ${ }^{15}$

Even when attempt liability is provided for in the definition of an offense, its usefulness in prosecuting alleged terrorists is constrained by the narrowness of attempt doctrine in the federal courts. Because the Federal Criminal Code does not provide a definition of attempt liability, the lower federal courts have adopted one as a matter of federal common law. Although the precise formulation varies across opinions and the circuits, the courts require that the defendant have made such substantial progress toward the completion of the offense that, absent frustration of the defendant's objective, the offense would have been committed. ${ }^{16}$ Under this

control over foreign affairs by regulating the private projection of force outside the United States").

${ }^{12}$ See 18 U.S.C. $\S 1111$ (murder within maritime or territorial jurisdiction of the United States); id. $\S 1114$ (murder of federal officer or employee in performance of official duties); see, e.g., Bin Laden, 92 F. Supp. 2d at 228 n.2 (1998 U.S. embassy bombings).

${ }^{13} C f$. MODEL PENAL CODE $§ 5.01(1)-(2)$ (1985) (proscribing attempted commission of Code offenses).

${ }^{14}$ See, e.g., 18 U.S.C. $\$ 1951$ ("Whoever in any way or degree obstructs, delays, or affects commerce . . . by robbery or extortion or attempts or conspires so to do ...."). As a consequence of such language, a conviction for attempting the crime has the same applicable punishment range as a conviction for the completed offense.

${ }^{15}$ See, e.g., 18 U.S.C. $\$ 844(f)$, (i) (punishing attempted damage of personal or real property); id. $\S 2332$ (b) (punishing attempted homicide); id. $\S 2332 \mathrm{a}$ (punishing attempted use of weapons of mass destruction).

${ }^{16}$ See, e.g., United States v. Nelson, 66 F.3d 1036, 1044 (9th Cir. 1995) ("Nor were [defendant's actions] a step toward the commission of the crime so substantial that without an intervening act the crime would have occurred."); United States v. Buffington, 815 F.2d 
stringent standard, situations that colloquially would be described as being "caught red-handed" may be inadequate to obtain a conviction for attempting the applicable crime. ${ }^{17}$ For this reason, attempt liability for inchoate offenses has limited effectiveness in prosecuting and punishing incipient acts of terrorism.

Unlike attempt, the Federal Criminal Code does contain a generally applicable conspiracy provision, which proscribes conspiracy to commit a federal offense. ${ }^{18}$ That section, however, carries a maximum penalty of only five years' imprisonment. ${ }^{19}$ Consequently, some federal offenses include conspiring to commit the crime as an independent means of violating the same statutory offense. ${ }^{20}$ Such a provision ensures that a person convicted of conspiring to commit the offense faces the same punishment range as a person who actually commits it, rather than the truncated punishment otherwise available under the default conspiracy provision. ${ }^{21}$

In addition, conspiracy law allows for conviction for an inchoate offense far earlier in the course of conduct than attempt liability. Technically speaking, the inchoate offense of conspiracy is completed once the members have concluded the agreement to commit the applicable underlying crime and one member of the conspiracy has engaged in some overt act pursuant to that agreement. ${ }^{22}$ Some terrorism cases involve prosecutions brought when the conspiracy is still in its very preliminary stages, such as when the plotters have reached agreement on a basic terrorist objective but have done little actual planning or preparation toward its

1292, 1303 (9th Cir. 1987) ("Standing alone, their conduct did not constitute that requisite 'appreciable fragment' of a bank robbery, nor a step toward commission of the crime of such substantiality that, unless frustrated, the crime would have occurred."). These formulations are based on the language of Model Penal Code. See Model PENAL CODE $\S$ 5.01(1)-(2); see also United States v. Rahman, 189 F.3d 88, 128-29 (2d Cir. 1999) (quoting and applying the Model Penal Code's attempt standard).

${ }^{17}$ See, e.g., Nelson, 66 F.3d at 1042-44; United States v. Harper, 33 F.3d 1143 (9th Cir. 1994); United States v. Still, 850 F.2d 607, 610 (9th Cir. 1988); Buffington, 815 F.2d at 1303. In Harper, for example, the court held that the defendants' actions in creating a "bill trap" at an ATM machine to lure a repair technician to the site, which would enable them to steal the cash inside when the technician opened the ATM for servicing, was not a step substantial enough to constitute an attempt; accordingly, the court reversed the convictions for attempted bank robbery. See 33 F.3d at 1145, 1147-48.

${ }_{10}^{18}$ See 18 U.S.C. $\$ 371$.

${ }^{19}$ See id.

${ }^{20}$ See supra notes $14-15$ and accompanying text.

${ }^{21}$ Compare 18 U.S.C. $\$ 1951$ (twenty years), with id. § 371 (five years); see also id. § 1117 (providing that conspiracy to commit murder is punishable by any term of years, or life).

${ }^{22}$ See, e.g., Joseph F. MCSORley, A Portable GuIDE to Federal Conspiracy LAW 6-28 (1996) (discussing elements of conspiracy formation). Some federal conspiracy statutes do not require an overt act, but most do. See id. at 24-28. The overt act need not itself be criminal; it can be a tangential or even trivial act, so long as it relates to the objectives of the agreement. See id. (citing cases). 
commission. The recent "Fort Dix" plot in New Jersey appears to be such a case. ${ }^{23}$ Other cases are brought when significantly more progress toward fulfillment of the conspiracy has been made and more corroborating evidence has been obtained. ${ }^{24}$

Inchoate offense liability, under conspiracy law in particular, provides a powerful tool for prosecuting, convicting, and punishing individuals whose objective is the commission of terrorist acts but whose plans are foiled before they can succeed.

\section{Vicarious Liability (Conspiracy \& Complicity)}

The liability doctrines of federal criminal law reach much further than personal participation in conduct directly related to carrying out a completed or planned act of terrorism, or even personal participation in an early-stage conspiracy intended to culminate in the commission of an offense. Instead, doctrines of vicarious liability make the defendant responsible for the conduct of other individuals, including instances when the defendant played a small, minimal, or even no role at all in that conduct. This liability can extend, in its greatest scope, to crimes the defendant did not know would be committed or to acts carried out by persons she has never met. Yet the defendant is equally guilty for those crimes as though she had committed them herself.

Federal conspiracy law provides the usual basis for imposing vicarious liability. The existence of a conspiratorial agreement requires specific intent on the part of its members to cooperate in a course of conduct that constitutes the planning and commission of federal offenses. ${ }^{25}$ Each member of the conspiracy then becomes guilty not only of the charge of conspiracy itself, but also of those substantive "object" ${ }^{\text {"26 }}$ offenses committed by any member of the group pursuant to the agreement. ${ }^{27}$ Thus, even if a particular member of the conspiracy has only a

${ }^{23}$ See Complaint at 4-7, United States v. Eljvir Duka, Magistrate No. 07-M-2047 (D.N.J. May 7, 2007), available at http://www.usdoj.gov/usao/nj/press/files /pdffiles/

ELJVIRDUKAcmplt.pdf (charging defendants with conspiracy to commit murder of federal officers and employees in violation of 18 U.S.C. $\$ \S 1114,1117$, as well as with a generic count of unlawful firearm possession by an illegal alien under 18 U.S.C. $\S$ 922(g)(5)); see also Chesney, supra note 11, at 487-92 (describing the prosecution of Hamid Hayat). Ultimately, the defendants were convicted of conspiracy. See Paul von Zeilbauer, 5 Men Are Convicted in Plot on Fort Dix, N.Y. TIMES, Dec. 22, 2008, at A3.

${ }^{24}$ See, e.g., United States v. Yousef, 327 F.3d at 80-85 (2d Cir. 2003) (involving a foiled 1995 airliner bombing plot); Moussaoui Indictment, supra note 7, at 1-24 (describing extensive preparations to carry out airline hijacking attack similar to 9/11).

${ }^{25}$ See MCSORLEY, supra note 22, at 6-24. The conspirators need only conspire to engage in the factual conduct (and corresponding mens rea) constituting the offenses; their knowledge or beliefs about the legal definitions of those offenses is irrelevant. See id. at 184-85.

${ }^{26}$ See id. at 7 (defining "object" of conspiracy).

${ }^{27}$ See id. at $109-10$. 
tangential role in the commission of one of the object offenses, he is convicted of that offense no differently than the conspirators who personally carried it out. ${ }^{28}$

Moreover, under the Pinkerton doctrine, additional vicarious liability may apply to offenses that the defendant never actually conspired to commit. Under Pinkerton, members of the conspiracy are liable not only for the object offenses specifically intended by the agreement, but also for any reasonably foreseeable additional substantive crimes committed in furtherance of the conspiracy. ${ }^{29}$ The Pinkerton doctrine is an especially powerful tool against violent crime conspiracies because additional violence by conspirators, above and beyond the specific acts of violence contemplated in the agreement, often will be deemed reasonably foreseeable. ${ }^{30}$

The prosecution of Zacarias Moussaoui demonstrates the breadth of federal conspiracy law. All six counts filed against Moussaoui were conspiracy charges, including terrorism transcending national boundaries, aircraft piracy, murder of federal officers and employees, and destruction of property. ${ }^{31}$ Much of the indictment recites a pattern of behavior by Moussaoui parallel to that of the September 11th hijackers, including undertaking flight training and communicating with the same al Qaeda leaders abroad. ${ }^{32}$ Accordingly, the Government argued that Moussaoui was a member of a terrorist conspiracy that included the September 11th hijackers and al Qaeda leaders. ${ }^{33}$ Although early media accounts of his case often referred to him as the so-called "twentieth hijacker, ${ }^{\text {,34 }}$ Moussaoui repeatedly denied he was directly involved in the September 11 th plot. He ultimately pled guilty to the charges,${ }^{35}$ however, and the

${ }^{28}$ See id. at $112-14$.

${ }^{29}$ See id. at 109-15. The doctrine's name comes from Pinkerton v. United States, 328 U.S. 640, 647 (1946).

${ }^{30}$ See, e.g., MCSORLEY, supra note 22, at 114 (citing cases in which Pinkerton was applied to extend liability for violent crimes). The additional violence must also be in furtherance of the objectives of the conspiracy, but this, likewise, usually is not difficult to prove. See id.

${ }^{31}$ See Moussaoui Indictment, supra note 7, at 2-31 (charging, inter alia, violations of 18 U.S.C. $\S \S 2332 b, 46502,1114,1117$, and $844(f)$, (i)). The remaining two counts were conspiracy to destroy aircraft, 18 U.S.C. $\$ \S 32,34$, and conspiracy to use a weapon of mass destruction, $\S 2332 \mathrm{a}$. See Moussaoui Indictment, supra note 7, at 2-31.

${ }^{32}$ See Moussaoui Indictment, supra note 7, at 5-7, 10-24.

${ }^{33}$ See id. at 6-7, 25-29.

${ }^{34}$ See, e.g., Frank Dunham, Constitutionalism and the War on Terror: Hamdi Meets Moussaoui in the War on Terror, 53 DRAKE L. REV. 839, 847 (2005) (referring to Moussaoui's alleged status as "the twentieth hijacker"); Tung Yin, Procedural Due Process to Determine "Enemy Combatant" Status in the War on Terrorism, 73 TENN. L. REV. 351, 412-13 (2006).

${ }^{35}$ See Criminal Docket, United States v. Moussaoui, No. 1:01-cr-00455 (E.D. Va. Apr. 22, 2005) ("PLEA entered by Zacarias Moussaoui. Court accepts plea by Zacarias Moussaoui Guilty: Zacarias Moussaoui (1) count(s) 1ss, 2ss, 3ss, 4ss, 5ss, 6ss (rtra) (Entered: 04/22/2005)"). 
Government sought the death penalty. ${ }^{36}$ At sentencing, the Government did not prove that Moussaoui had personally participated in the planning or commission of the September 11th attacks or even that he had knowledge of the specific attacks being planned by others. ${ }^{37}$ Nonetheless, the Government maintained that he was vicariously liable for them under Pinkerton because the September 11th attacks were reasonably foreseeable crimes committed in furtherance of the same terrorist conspiracy of which Moussaoui was a member. ${ }^{38}$ Although the jury agreed with many of the Government's assertions, they ultimately recommended a sentence of life imprisonment without the possibility of release, ${ }^{39}$ which the judge imposed. ${ }^{40}$

Although conspiracy law frequently is used to attach vicarious liability, the Federal Criminal Code also provides for vicarious liability for complicity - that is, "aiding and abetting" the commission of an offense. ${ }^{41}$ Like a conspirator, an accomplice who aids and abets a crime is equally guilty of that offense, even though she did not personally participate in its actual commission. ${ }^{42}$ Unlike Pinkerton liability, however, which attaches solely due to the defendant's membership in a conspiracy, complicity liability requires that the defendant have assisted the commission of the crime in some personal, direct way ${ }^{43}$ Accordingly,

${ }^{36}$ See Special Verdict Form for Phase II at 2, United States v. Moussaoui, Criminal No. 01-455-A (E.D. Va. April 24, 2006) [hereinafter Moussaoui Special Verdict Form].

${ }^{37}$ This problem arose in part because the Government refused to allow Moussaoui access to three captured al Qaeda leaders who could have provided exculpatory testimony on exactly that issue. See United States v. Moussaoui, 382 F.3d 453, 463-64 (4th Cir. 2004) (addressing the Government's violation of, and the appropriate remedy under, the Compulsory Process Clause), aff'g United States v. Moussaoui, 365 F.3d 292 (4th Cir. 2004) (same).

${ }^{38}$ See Moussaoui Special Verdict Form, supra note 36, at 1, 15, 29. The Government sought the death penalty on counts one, three, and four, charging conspiracy to commit acts of terrorism transcending national boundaries, to destroy aircraft, and to use a weapon of mass destruction, respectively. See id. at 2, 15, 29.

${ }^{39}$ See Jury Verdict Form for Phase II at 13, 27, 41, United States v. Moussaoui, Criminal No. 01-455-A (E.D. Va. May 3, 2006). Notably, three jurors specifically made a finding "[t]hat Zacarias Moussaoui had limited knowledge of the 9/11 attack plans" and believed it was a mitigating factor in favor of a life sentence. See id. at 9, 23, 37 .

${ }^{40}$ See Judgment in a Criminal Case at 2, United States v. Moussaoui, No. 1:01CR00455-001 (E.D. Va. May 4, 2006).

${ }^{41}$ See 18 U.S.C. $§ 2$ (2006); see also MCSORLEY, supra note 22, at 56-62 (discussing $\S 2)$.

${ }^{42}$ Under complicity liability, a person who aids and abets the commission of an offense "is punishable as a principal." 18 U.S.C. $§ 2(a)$; see also MCSORLEY, supra note 22 , at 56-57 ("Aiding and abetting ... is a vehicle for secondary liability that renders an aider and abettor culpable as a principal.").

${ }^{43}$ See MCSORLEY, supra note 22, at 112 (noting that, when both theories are argued by the prosecution, the jury must be unanimous regarding whether defendant is guilty because of Pinkerton liability or complicity liability); see also id. at 57-58 (describing complicity liability). 
the primary benefit of the aiding and abetting theory is to prosecute those who assist the commission of crimes without ever joining the conspiratorial agreement. $^{44}$

\section{Facilitation Liability (Material Support)}

In contrast to the first three forms of liability, the fourth form of liability relies on a different type of conduct by the defendant. Instead of proving the defendant's personal participation or vicarious involvement in activities leading to specific completed or inchoate incidents of terrorism, under the "material support" offenses, the Government can obtain a conviction based on facilitation liability; ${ }^{45}$ that is, a defendant is guilty of facilitating terrorism when he knowingly rendered aid to terrorists without knowing the manner in which the aid would be used. ${ }^{46}$ The conviction entered is not for terrorist activities directly, but rather for the distinct, independent facilitation offense. ${ }^{47}$

\section{${ }^{44}$ See id. at 59.}

45 See generally 1 PAUL H. RoBInSON, CRIMTNAL LAW DEFENSES $\S \S 81-85$ (1984 \& Supp. 2008) (describing and analyzing facilitation liability); 2 WAYNE LAFAVE, SuBSTANTIVE CRIMINAL LAW $\S 13.2 n .111$ (2d ed. $2003 \&$ Supp. 2007) (describing the mens rea for facilitation liability as based on knowledge, rather than purpose).

${ }^{46}$ If the defendant did know the manner in which his aid would be used, then the defendant would be part of a conspiracy to commit the relevant crimes. Accordingly, the material support offenses expand liability to cover situations in which the defendant lacks the necessary mens rea for conspiracy to commit any particular crimes but is nevertheless knowingly aiding terrorists in doing something.

${ }^{47}$ The concept of "material support" for terrorism originated in 18 U.S.C. $\S 2339 \mathrm{~A}$, enacted in 1994. See Robert M. Chesney, The Sleeper Scenario: Terrorism-Support Laws and the Demands of Prevention, 42 HARV. J. ON LEGIS. 1, 12-13 (2005). That offense punishes a person who "provides material support or resources ... knowing or intending that they are to be used in preparation for, or in carrying out, a violation of" listed federal offenses relating (directly or implicitly) to terrorism prosecutions. 18 U.S.C. $\S 2339$ A(a). On the one hand, like a facilitation offense (including $\S 2339 \mathrm{~B}$, which was enacted in 1996), the defendant is not made vicariously liable for the actual offenses for which he provided material support; instead, the defendant is convicted and punished (by up to fifteen years' imprisonment) under $\S 2339$ A. See Chesney, supra, at 13-18. On the other hand, like conspiracy or complicity, the Government must prove that the defendant had mens rea with respect to particular terrorist objectives. See id. at 13 ("It is, in short, a type of aiding-and-abetting statute."). Thus, although $\S 2339 \mathrm{~A}$ is not a basis for imposing vicarious liability, it does not serve the function of a facilitation offense, either. $C f$. Chesney, supra note 11, at 479-80 (noting that, although $\S 2339 \mathrm{~A}$ requires knowledge or intent to support predicate offenses, it more broadly proscribes supporting preparations for, or supporting conspiracies to engage in, predicate offenses as well as the narrower proscription on supporting commissions of predicate offenses). Likewise, the necessary mens rea often makes $\S 2339$ A superfluous, because the same mens rea also would support a full conspiracy charge, rather than the lesser material support charge. See id. at 482-83, 486. 
The most frequently charged material support offense is $\S 2339 \mathrm{~B}$, which makes knowingly providing "material support or resources" to a designated "foreign terrorist organization" (FTO) a felony punishable by up to fifteen years' imprisonment. $^{48}$ The definition of material support is expansive, including providing money or financial services, training or personnel, transportation or lodging, or weapons or explosives. ${ }^{49}$ The list of designated FTOs is maintained by the U.S. Department of State, and that list is incorporated by reference in $\S 2339 \mathrm{~B} .{ }^{50}$ To be convicted under $\S 2339 \mathrm{~B}$, the defendant either must know that the group to which she is rendering support is actually on this list, or more broadly must know that the organization engages in terrorism. ${ }^{51}$ Thus, the recipient of the defendant's material support need not be specific individual terrorists preparing a particular attack, but rather can be simply the FTO in general.

Many of the prominent terrorism cases since 2001 have involved charges under $\S 2339 B$. For example, the "Lackawanna Six" defendants in upstate New York, an alleged al Qaeda "sleeper cell," pleaded guilty to $\S 2339 \mathrm{~B}$ charges, ${ }^{52}$ as did the "American Taliban," John Walker Lindh. ${ }^{53}$ Accused terrorist fundraiser Sami Al-Arian was acquitted on material support charges, although he ultimately pleaded guilty to conspiracy to raise funds for an FTO. ${ }^{54}$ Another American, Adam

${ }^{48} 18$ U.S.C. $\S 2339 \mathrm{~B}(2006)$.

${ }^{49}$ See id. $\$ \S 2339(\mathrm{~g})(4), 2339 \mathrm{~A}(\mathrm{~b})$.

${ }^{50}$ See 8 U.S.C. $\S 1189$ (2006); 18 U.S.C. $\S 2339 \mathrm{~B}(\mathrm{~g})(6)$ (2006).

${ }^{51}$ See 18 U.S.C. $\S 2339 \mathrm{~B}(\mathrm{a})(1)$. The requisite knowledge was clarified by the Intelligence Reform and Terrorism Protection Act of 2004 to resolve statutory interpretation issues raised by the lower courts under the prior version of the statute. See Pub. L. No. 108-458, § 6603(c), 118 Stat. 3638, 3762-63; see, e.g., Humanitarian Law Project v. Gonzales, 380 F. Supp. 2d 1134, 1147-48 (C.D. Cal. 2005) (discussing Humanitarian Law Project v. United States Dep't of Justice, 352 F.3d 382 (9th Cir. 2003), vacated, 393 F.3d 902 (9th Cir. 2004) and United States v. Al-Arian, 308 F. Supp. 2d 1322 (M.D. Fla. 2004), reh'g denied, 329 F. Supp. 2d 1294 (M.D. Fla. 2004)).

${ }_{52}$ See United States v. Goba, 240 F. Supp. 2d 242, 258 n.20 (W.D.N.Y. 2003) (discussing the "Lackawanna Six" guilty plea under § 2339B); Chesney, supra note 47, at 39-44; see also United States v. Goba, 220 F. Supp. 2 d 182 (W.D.N.Y. 2002) (discussing the allegations against the "Lackawanna Six" and ordering pretrial detention without bail).

${ }^{53}$ See Neil A. Lewis, Admitting He Fought in Taliban, American Agrees to 20-Year Term, N.Y. TiMEs, July 16, 2002, at A1; see also United States v. Lindh, 212 F. Supp. 2d 541 (E.D. Va. 2002) (discussing charges against defendant and denying defendant's motion to dismiss).

${ }^{54}$ See Plea Agreement at 1, 3, United States v. Al-Arian, No. 8:03-CR-77-T-30TBM (M.D. Fla. Apr. 14, 2006); Verdict at 7, United States v. Al-Arian, No. 8:03-CR-77-T30TBM (M.D. Fla. Dec. 6, 2005) [hereinafter Al-Arian Verdict]; Chesney, supra note 11, at 465 (noting acquittal on § 956 charge); see also United States v. Al-Arian, 329 F. Supp. 2d 1294, 1295 (M.D. Fla. 2004) (describing defendant's conviction for conspiracy to raise funds for an FTO); United States v. Al-Arian, 308 F. Supp. 2d 1322, 1329, 1350-51 (M.D. Fla. 2004) (describing charges against defendant under $\S 2339 \mathrm{~B}$ ). 
Gadahn, is currently under indictment on $\S 2339 \mathrm{~B}$ charges for providing personnel and services to al Qaeda. ${ }^{55}$

Although $\S 2339 \mathrm{~B}$ is the most prominent example, several other facilitation offenses also can be charged in terrorism cases. These offenses include the crimes of harboring terrorists and financing terrorism, which carry penalties of up to ten and twenty years' imprisonment, respectively. ${ }^{56}$ Like $\S 2339 \mathrm{~B}$, these offenses do not make the defendant liable for the terrorist activities as such, but rather for a separate crime imposing liability on a facilitation theory. Similarly, another statute makes it a felony, punishable by up to ten years' imprisonment, to "knowingly receive military-type training from or on behalf of" an FTO.$^{57}$ This statute, rather than $\S 2339 \mathrm{~B}$, likely would be used to charge defendants in future cases similar to Lindh or Gadahn. ${ }^{58}$

Thus, the facilitation offenses, and the $\S 2339 \mathrm{~B}$ material support crime in particular, expand criminal liability even further than conspiracy law's vicarious liability. Under the facilitation offenses, a defendant can be convicted for knowingly supporting terrorists, even if the defendant had no idea of the terrorists' future plans for using that support. This offense marks a stark departure from personal or vicarious liability, which require proof of the defendant's involvement in specified crimes. Even generalized support for unspecified terrorist goals creates significant felony liability.

\section{B. The Complexities}

Given the preceding discussion, it might appear that prosecuting terrorists under the U.S. federal criminal laws is relatively straightforward, and that the difficulties would arise in proving of the requisite facts beyond a reasonable

${ }^{55}$ See Gadahn Indictment, supra note 1, at 9.

${ }^{56}$ See 18 U.S.C. $\S 2339$ (harboring); id. § 2339C (financing).

${ }^{57}$ See 18 U.S.C. $\$ 2339 D$. This offense was enacted in the Intelligence Reform and Terrorism Protection Act of 2004. See Pub. L. No. 108-458, § 6602, 118 Stat. 3638, 3761 (2004)

${ }^{58}$ The Intelligence Reform and Terrorism Protection Act of 2004 also amended the definition of material support in $2339 \mathrm{~A}(\mathrm{~b})$ to clarify that "personnel" is defined as "(1 or more individuals who may be or include oneself)." See Pub. L. No. 108-458, § 6603(b), 118 Stat. 3638, 3762. Prior to the 2004 amendments, the lower courts had raised significant statutory interpretation questions regarding the application of $\S 2339 \mathrm{~B}$ to individuals whose only alleged provision of material support was "personnel" in the form of their own personal participation in Taliban or al Qaeda training camps. See, e.g., Humanitarian Law Project v. Reno, 205 F.3d 1130, 1137 (9th Cir. 2000); United States v. Lindh, 212 F. Supp. 2d 541, 574 (E.D. Va. 2002). After the Act, such individuals can be prosecuted under $\S 2339 \mathrm{D}$, as well as the amended $\S 2339 \mathrm{~B}$. Due to the Ex Post Facto Clause, the prior version of $\S 2339 \mathrm{~B}$ continues to be charged for such conduct prior to the 2004 Act. See, e.g., Gadahn Indictment, supra note 1, at 9 (charging $\S 2339 \mathrm{~B}$, not $\S 2339 \mathrm{D}$, based on conduct occurring prior to Act). 
doub $\mathrm{t}^{59}$ rather than in resolving questions of the application or interpretation of the law. In fact, there are several significant aspects of existing criminal law doctrine which are complex and controversial under any circumstance. The context of terrorism prosecutions tests these complexities to their outer limits.

The most prominent and important-and most problematic-issue is determining the scope of a conspiratorial agreement. Both the nature of the object offenses of the conspiracy and the extent of vicarious liability for the crimes committed by the members of the conspiratorial group depend on the scope of the agreement. The conspiracy's scope, therefore, is crucial for deciding a given defendant's fate. Yet the law of conspiracy provides very little guidance for defining the scope of any given conspiratorial agreement. Instead, the question of a conspiracy's scope is almost entirely one of fact. Consequently, the Government has every incentive to try to describe the conspiracy as extensively as possible, while the defendant's interests are served by describing it as narrowly as possible. $^{60}$

The scope of a conspiratorial agreement varies on two axes: the identity of the agreement's membership (who) and the criminal content of the agreement (what). When the stakes are as high as they are in crimes of terrorism, each axis can prove critical in shaping the indictment, trial, and punishment of the accused terrorists.

The first question is who is involved in the conspiracy: which individuals are part of the conspiratorial group and its criminal agreement? The answer determines the extent of the vicarious liability faced by all of the conspirators. ${ }^{61}$ Every single one of the conspirators is liable for crimes committed by other conspirators pursuant to the conspiracy - that is, the agreement's object offenses. ${ }^{62}$ They also are liable for crimes committed by other conspirators in furtherance of the conspiracy's objectives, although not specifically agreed to - that is, reasonably

59 See Chesney, supra note 11 , at $464-86$ (describing dispositions of $\S 956$ and $\S$ 2339A cases, including acquittals); see also Al-Arian Verdict, supra note 54, at 7 (acquitting defendant of three material support counts under 18 U.S.C. $§ 2339 \mathrm{~B}(\mathrm{a})(1)$ and 18 U.S.C. $\$ 2$ ).

${ }^{60}$ The opposite incentives exist when the inchoate aspect of conspiracy is implicated, but there is no vicarious liability for completed (or attempted) object or Pinkerton offenses to impute. In that situation the Government's incentive is to describe multiple, narrow agreements to sustain multiple counts of conspiracy (and consequently more total punishment), while the defendant's interest is served by having fewer, broader conspiracies (and consequently less total punishment). See, e.g., Braverman v. United States, 317 U.S. 49, 53 (1942) (holding that where defendants' agreed course of conduct constituted violations of seven different tax offenses and the Government charged seven counts of conspiracy, the defendants had entered one agreement creating a single conspiracy relating to a course of conduct and not seven agreements creating seven conspiracies).

${ }^{61}$ See supra notes 25-30 and accompanying text; see also Chesney, supra note 11 , at 466-73 (discussing conspiratorial vicarious liability).

${ }^{62}$ See MCSORLEY, supra note 22, at 109-10. 
foreseeable Pinkerton offenses. ${ }^{63}$ But to impose liability, of course, either object offenses or Pinkerton offenses must have been committed by a member of the same conspiracy to which the defendant belongs. ${ }^{64}$ For example, if supplier $A$ conspires with dealers $B, C$, and $D$ to sell cocaine, none of them is liable for cocaine sales by dealer $E$ if $E$ is not a member of their conspiracy.

Certainly defendants are members of the same conspiracy if they personally, directly agreed with each other. Two individuals also may be found to be part of the same conspiracy even if they do not directly interact, so long as they are aware of the existence of other participants in the same agreement. ${ }^{65}$ Such conspiracies might take the form of a "chain" with a series of links, or a "wheel" with a central figure coordinating the efforts of others-or both. ${ }^{66}$ For example, even if $B$ and $D$ never meet, or do not even know each other's names, $D$ is nonetheless part of the same conspiracy as $B$ if $D$ conspires with supplier $A$ knowing that $A$ is conspiring with other dealers, as well (one of whom happens to be $B$ ) ${ }^{67}$

The criminal law has no bright-line principle for determining which individuals are members of a given conspiracy; rather that determination is made through a finding of fact. It begins when the Government makes factual allegations about the scope of the conspiracy's membership in the indictment. If the defendant does not plead guilty to some or all of the relevant conspiracy-related counts, then the Government must prove beyond a reasonable doubt to a jury that its assessment of the factual situation is correct. ${ }^{68}$ The decisions made on the questions of fact about the scope of the conspiracy's membership determine the extent of the defendant's liability.

Terrorism prosecutions can press this fact-based standard to its limits. A simple, uncontroversial charge would assert that the individuals personally involved in a particular terrorist plot are members in the same conspiracy. At the other, controversial extreme the Government might claim that all members of al Qaeda are part of the same overarching conspiracy to commit terrorist acts. The prosecution in Moussaoui was somewhere in the middle. Although the Government could not prove that Moussaoui was a direct participant in the group of individuals who prepared for and carried out the September 11th attacks, it did maintain that he conspired with the same al Qaeda handlers and leaders to commit

${ }^{63} I d$.

${ }^{64}$ See id. at 114-15; Chesney, supra note 11 , at $450-51$.

${ }^{65}$ See MCSORLEY, supra note 22, at 143-46.

66 "A typical chain conspiracy involves relationships between wholesalers, retailers, sellers, brokers, and purchasers." Id. at 144. "When different persons (spokes) are involved with a common individual or group (the hub), a successful conspiracy prosecution may depend on whether the spokes can be drawn together (connected by a rim) into a single agreement." Id. at 145 .

${ }^{67}$ See Model Penal CODE $§ 5.03(2)$ (1985); see also MCSORLEY, supra note 22, at 146 (discussing marijuana importation "wheel" conspiracy in United States v. Champion, 813 F.2d 1154, 1165-67 (11th Cir. 1987)).

${ }^{68}$ See MCSORLEY, supra note 22, at 146-52; Chesney, supra note 11, at 473-74. 
highly similar attacks - and therefore was a member of the same conspiracy as the September 11th hijackers, as another "spoke" in the wheel conspiracy formed by the leaders at its "hub." the conspiracy's membership, the Government was obligated to stop there. If it were possible to prove, factually, that a defendant conspired with high-level al Qaeda leaders, then in theory it would be possible to claim, as a factual matter, that he was a member of the same conspiratorial group as all other members of al Qaeda who also gave their allegiance to the same leaders. If such a claim were accepted, then the defendant would be responsible for all object and Pinkerton offenses committed by any member of al Qaeda. ${ }^{70}$ The Government rarely pursues such an expansive conspiracy charge, but it is not for lack of legal authority. ${ }^{71}$ After all, the potential to charge an extensive conspiracy with a large membership exists in other kinds of large network criminality cases as well, such as narcotics

${ }^{69}$ Specifically, Ramzi Bin al-Shibh was portrayed as the mastermind behind both Moussaoui's activities and those of Mohammed Atta, whose highly similar plot culminated in the 9/11 attacks; thus, because both Moussaoui and Atta conspired with the same person to carry out airliner attacks, the Government maintained that there were not two separate airliner conspiracies, but rather a single larger one (led by Bin al-Shibh), of which both Moussaoui and Atta were a part. See Moussaoui Indictment, supra note 7, at 6-7, 10-24.

${ }^{70}$ Subject, of course, to the crime occurring either in the United States or in a place or manner over which the U.S. has extraterritorial criminal jurisdiction. See supra note 1.

${ }^{71}$ See Chesney, supra note 11 , at 466-74 (describing § 956 conspiracy charges predicated on connections to FTOs or the global jihad movement). Alternatively, if the Government wishes to pursue an expansive theory of liability based on the activities of al Qaeda as a whole, the Racketeer Influenced and Corrupt Organizations Act (RICO) may be a better theory, rather than a charge under a traditional conspiracy theory. Under RICO, a defendant may be convicted for operating or managing the "affairs" of a criminal "enterprise" affecting interstate commerce "through a pattern of racketeering activity." 18 U.S.C. $\S 1962$ (c) (2006) (offense); see also id. § 1961 (definitional provisions); Reves v. Ernst \& Young, 507 U.S. 170, 182-83 (1993) (discussing what qualifies a defendant as an operator or manager in the affairs of the enterprise); United States v. Turkette, 452 U.S. 576, 590 (1981) (discussing the application of RICO to an enterprise consisting of an association-in-fact with illegal objectives). In addition to the leaders of a criminal enterprise, RICO also reaches those subordinates who are not themselves eligible RICO defendants but who conspire with the enterprise's leaders (who are personally violating RICO). See 18 U.S.C. $§$ 1962(d); Salinas v. United States, 522 U.S. 52, 66 (1997) (upholding the conviction of an individual, who did not qualify as an operator or manager under $\S 1962(c)$, on a charge of RICO conspiracy under $\S 1962(d)$ ). Thus, RICO potentially could be charged not only against high-level al Qaeda leaders who personally direct or supervise the organization's terrorist activities, but also against the operatives who conspire with them to carry out the pattern of criminal activity in violation of RICO. To date, however, RICO charges have been rare in terrorism cases. See Chesney, supra note 11 , at 467 n.205. 
trafficking or organized crime families. ${ }^{72}$ Yet the Government rarely indicts a street-level distributor in the same conspiracy as the importer who acquires massive quantities of cocaine from Colombia, even though an "ordinary" dealer presumably is aware that importation is a necessary link between production and retail in the overall cocaine distribution chain. ${ }^{73}$ Thus, it is only the Government's exercise of prosecutorial discretion in the interests of fairness and justice, or perhaps issues of factual proof beyond a reasonable doubt, which restrain the breadth of membership alleged in conspiracy indictments.

The second question is what constitutes the conspiratorial agreement: which crimes are the objectives of the group's criminal agreement? As with membership, the answer determines the extent of the conspirators' vicarious liability. All members of the conspiracy are liable for its object offenses when they are committed, regardless of their level of personal involvement, if any, in the carrying out of any given crime. ${ }^{74}$ Similarly, the nature of the object offenses of the conspiracy will delimit which additional crimes, committed by conspirators in furtherance of the agreement's objectives, are — or are not - reasonably foreseeable Pinkerton offenses for which the other conspirators are equally liable. ${ }^{75}$

Just like the scope of membership, the scope of the agreement's content also is a question of fact. For example, $A, B$, and $C$ might conspire to sell cocaine, and $A$ and $D$ might conspire to engage in money laundering to conceal the proceeds, creating two separate conspiratorial agreements. Alternatively, $A, B, C$, and $D$ might form a single agreement to sell cocaine and launder money. Which characterization is the "correct" one is a factual conclusion about how many separate agreements there are, and the content of each. ${ }^{76}$ Importantly, the decisive determination is the number of agreements, not the number of object offenses, because a single agreement can comprise many object offenses. ${ }^{77}$ Just as broader membership expands the potential vicarious liability for the actions of more individuals, so too a broader scope of the criminal agreement creates the possibility of more vicarious liability for more object offenses and more corresponding

${ }^{72}$ See, e.g., United States v. Gotti, 451 F.3d 133, 134-35 (2d Cir. 2006) (charging conspiracy in a case involving an organized crime family); United States v. Sessa, 125 F.3d 68,70 (2d Cir. 1997) (charging conspiracy in a case involving narcotics trafficking).

${ }^{73}$ Cf. Stephen J. Schulhofer, Assessing the Federal Sentencing Process: The Problem is Uniformity, Not Disparity, 29 AM. CRIM. L. REV. 833, 855-56 (1992) (noting that the Federal Sentencing Guidelines base a defendant's punishment in narcotics cases on personal conduct, not the entire distribution chain).

${ }_{75}^{74}$ See MCSORLEY, supra note 22, at 109-11.

${ }^{75}$ See id. at $114-15$.

${ }_{77}^{76}$ See id. at 45-49, 131-43; Chesney, supra note 11, at 473-74.

${ }^{77}$ See Braverman v. United States, 317 U.S. 49, 53 (1942) (holding that a single agreement to engage in a course of conduct, which constituted seven different tax offenses, created a single conspiracy and not seven conspiracies). 
Pinkerton offenses in the course of the conspiracy. ${ }^{78}$ Regardless of the breadth or narrowness of its content, a conspiracy charge necessarily requires an agreement to engage in activity that would constitute the violation of the relevant criminal statutes. $^{79}$ That is, the Government must charge a conspiracy to commit specified offenses, not simply a generalized agreement to do yet-to-be-determined bad things. ${ }^{80}$

The prosecution of alleged terrorists creates the potential for testing the limits of this fact-based standard, as well. If the Government relies on a facilitation offense, of course, then the issue does not come into play; generalized support to an FTO for unspecified purposes, for example, violates $\S 2239 \mathrm{~B}$. When the charge is conspiracy, however, and the Government seeks to impose vicarious liability for crimes committed by others, then the scope of the conspiratorial agreement's content is crucial. On one hand, an agreement "to attack $X$ target by $Y$ means on $Z$ date" clearly is precise enough to constitute a conspiracy to commit the delineated actus reus elements of the statutory offenses relevant to the $X$ and $Y$ factors-for example, causing the deaths of other human beings for murder, or destroying a federal building by explosives under $\S 844 .^{81}$ On the other hand, an agreement "to carry out some kind of terrorist attack eventually" is almost certainly too ambiguous and undefined to permit the conviction, beyond a reasonable doubt, of its participants for a conspiracy to commit any specific offenses - the Government would be unable to allege which particular actus reus elements of which particular crimes the defendants were actually conspiring to commit. ${ }^{82}$

In between are agreements with varying degrees of specificity that might or might not sustain a valid, or at least an uncontroversial, conspiracy charge. For example, an agreement "to start figuring out how to go about building a dirty bomb to detonate in a major American city" could be charged as a conspiracy to commit a weapon of mass destruction offense, even if the implementation of the agreement

${ }^{78}$ See Mark Noferi, Towards Attenuation: A "New" Due Process Limit on Pinkerton Conspiracy Liability, 33 AM. J. CRIM. L. 91, 113 (2006) (describing the vast potential breadth of liability under Pinkerton).

${ }^{79}$ See MCSORLEY, supra note 22, at 7-9; Chesney, supra note 11, at 451-58.

${ }^{80}$ See Chesney, supra note 11, at 452-53 (citing United States v. Gallishaw, 428 F.2d 760, 763-64 \& n.1 (2d Cir. 1970); United States v. Rosenblatt, 554 F.2d 36, 38-39 (2d Cir. 1977)); see also id. at 465-69 \& n.211, 474 (discussing required specificity for $\S 956$ conspiracy charges as an agreement to commit violence against persons abroad, but not the identification of particular victims or the manner of violence).

${ }^{81}$ See supra note 9 and accompanying text for a discussion regarding Section 844.

${ }^{82}$ In the hypothetical conspiracy, the agreement is so ambiguous and undefined ("some kind of terrorist attack") that the Government might be unable to prove beyond a reasonable doubt even a conspiracy to commit the actus reus of murder. That is, because some forms of terrorism involve property damage but no loss of life, the defendants might be able successfully to raise doubt about whether their agreement necessarily contemplated causing deaths. 
is only in its preliminary stages, ${ }^{83}$ because the specific intent to carry out the delineated actus reus elements of that object offense is present. But an agreement "to kill some Americans somewhere at some point in time by some means to be determined later" is arguably too indistinct even to constitute a conspiracy to commit murder. ${ }^{84}$ Of course, in cases where proof of a conspiracy to commit particular offenses will be difficult to obtain, the Government can exercise its prosecutorial discretion to pursue facilitation charges rather than conspiracy and thereby avoid the need to specify any agreement—at the cost of abandoning vicarious liability. Thus, when vicarious liability is in play, it is the Government's ability to prove the scope of the agreement's content beyond a reasonable doubt that limits the breadth of the conspiracy. ${ }^{85}$

Taken together, these two axes of a conspiratorial agreement give the Government considerable authority to aggressively charge and prosecute terrorism cases. The Government can seek to define the membership of the agreement with great horizontal and vertical breadth, casting the net of liability for others' crimes as wide as possible. Likewise, the Government can frame the objectives of the conspiracy in equally broad terms, including as many object offenses as possible within its scope. To the extent that there are constraints on such charging practices, they are not doctrinal, but factual. A jury, for example, might not be persuaded beyond a reasonable doubt that one group of terrorists plotting an airliner attack really is part of the same conspiratorial agreement as others planning to bomb a U.S. embassy, even though both groups report to the same "supervisor" in al Qaeda. Or a defendant might refuse to plead guilty to an expansively drawn conspiracy charge, but be willing to plead to a narrower one.

Moreover, the earlier in the terrorist endeavor the criminal charges are filed, the more difficult it may be to obtain definitive evidence about the agreement's membership and objectives. ${ }^{86}$ That is, the more inchoate the nature of the conspiracy, the more difficult it may be to prove beyond a reasonable doubt exactly who and what the conspiracy is. Sometimes direct evidence may exist, such as when a participant in the conspiracy testifies for the Government. Even then, however, a conspiracy in the preliminary stages of agreement and planning must be proven more by inference and intent than one further along, which may

${ }^{83}$ See id. at 457-58 (concluding that conspiracy to bomb yet-to-be-determined buildings is sufficient to sustain conspiracy charge (citing United States v. Salameh, 152 F.3d 88, 145-48 (2d Cir. 1998))).

${ }^{84}$ Consider, for example, an agreement between $A$ and $B$ to kill $C$, while leaving the time, place, or manner of the killing to be figured out later. In that situation, the selection of a particular victim makes possible the identification of a specific object offense - the murder of $C$. A conspiracy "to commit the murder of somebody" fails to provide even that level of specificity.

85 "The more remote the defendant is from the group's violent activities, the more difficult it becomes to prove that the defendant specifically intended those activities to occur." Id. at 469 n.211.

${ }^{86}$ See id. at 434 . 
have substantial evidence of actions in preparation and other corroborative activities. ${ }^{87}$ In the end, therefore, it is ultimately proof and persuasion, not law, which determine how extensive the scope of conspiracy charges and convictions will become in terrorism prosecutions.

Two other situations presented by the threat of terrorism illustrate complexities in the existing criminal law doctrines. These situations do not fit neatly within the current doctrinal frameworks, highlighting the need to think creatively and flexibly to ensure that terrorist activity worthy of criminal sanction falls within the reach of the law.

One situation is the problem of "sleeper cells," small groups of terrorists who infiltrate civilian society and undertake ordinary daily lives - until the point in time arrives when they are "awakened" to engage in terrorist activity. ${ }^{88}$ Sleeper cells may be put into place without specific, predetermined plans for what kind of activity they ultimately will be asked to carry out; instead, they may be awaiting instructions about what to do, and only begin preparing to commit terrorist acts once operational orders arrive ${ }^{89}$ Surveillance, confidential informants, or fruits of other antiterrorism investigations, for example, may be able to identify sleeper cells prior to activation. But in such circumstances, it is likely that conspiracy charges may not be viable because the Government will be unable to prove beyond a reasonable doubt an agreement to engage in specified, particular object offenses. Accordingly, facilitation offenses may be the only charges available against such individuals. But the $\S 2339 \mathrm{~B}$ offense applies to all forms of providing material support, without differential penalties for conduct that is more or less directly or indirectly connected to ultimate terrorist attacks. Thus, $\S 2339 \mathrm{~B}$ fails to distinguish between an al Qaeda fundraiser, who supports the organization financially, and a sleeper cell operative, who intends to one day personally carry out a terrorist attack. $^{90}$

87 The terrorist plot to blow up United States-bound airliners foiled by British authorities in August 2006 illustrates this dilemma. "British law enforcement officials, for instance, typically wait longer to arrest terrorism suspects than do American authorities, [Martin R. Pollner, senior partner at the law firm Loeb \& Loeb in New York and a former United States representative to Interpol, the international police network] said, because the British want to let a plot develop further so they have stronger evidence when it comes to prosecuting a case." Heather Timmons \& Eric Pfanner, Europe Says It Will Unify Effort in Fight on Terrorism, N.Y. TIMES, Aug. 17, 2006, at A15. Rather than making arrests soon after the plot was uncovered, British authorities engaged in "months of surveillance of the suspects" before arresting them and acquired significant amounts of corroborating evidence by doing so. Alan Cowell, Britain Charges 11 in Plane Case, N.Y. TIMES, Aug. 22, 2006, at A1.

${ }^{88}$ See Chesney, supra note 47 , at $1-2$ \& n.2, 71.

${ }^{89} \mathrm{Cf}$. Chesney, supra note 11 , at $488-92$ (describing the prosecution, and quoting the interrogation, of Hamid Hayat).

${ }_{90}$ In some circumstances, the $\S 2339 \mathrm{D}$ offense is a step toward addressing this disparity. Terrorists concealed in sleeper cells may have engaged in the requisite military- 
Similarly, the $\S 2339 \mathrm{~B}$ offense makes no distinction between a person who provides a safe house or forged identity papers to terrorists, and a sleeper cell operative who procures weapons or bomb-making materials in anticipation of possible (but not certain) future use by himself or fellow terrorists. Perhaps the existing terms of $\S 2339 \mathrm{~B}$ strike an appropriate balance between those who knowingly advance terrorist objectives through indirect, generalized assistance and those who provide direct, tailored support but are not quite inculpated enough to prove involvement in a specific conspiratorial agreement. On the other hand, it is not obvious that a "fellow traveler" who donates money to al Qaeda, but would never commit an act of terrorist violence personally, should have equal culpability with a "terrorist in waiting" who waits only for detailed instructions before becoming a deadly, active terrorist himself. The sleeper cell situation exemplifies the constant need to adapt criminal law offenses and punishments to the terrorist threat.

The other problematic situation is that of "unaffiliated" terrorism. ${ }^{91}$ Also called "wannabe" or "homegrown" terrorists, these individuals aspire to take part in the destructive agenda of al Qaeda but are not connected to it and do not cooperate with it. For example, the men charged with plotting to attack Fort Dix in New Jersey appear to have no connection to al Qaeda. ${ }^{92}$ Likewise, the Miami men indicted for planning to bomb the Sears Tower in Chicago do not seem to have any affiliation with foreign terrorists. ${ }^{93}$ Of course, affiliation with al Qaeda or any other terrorist organization is not a necessary element of committing, attempting, or conspiring to commit acts of terrorism in the first place, so such individuals will be convicted for the relevant crimes irrespective of their "lone wolf" nature. On the other hand, existing federal criminal law does not impose facilitation liability in relation to unaffiliated terrorists. In particular, § 2339B only proscribes providing material support to foreign terrorist organizations designated by the State Department. ${ }^{94}$ Rendering material support to domestic terrorists who have no

type training in al Qaeda camps prior to being deployed as sleeper cell operatives and accordingly could be convicted under $\S 2339 \mathrm{D}$. A fundraiser who has never undertaken such training, by contrast, could be reached only under $\S 2339 \mathrm{~B}$, or possibly the $\S 2339 \mathrm{C}$ financing offense. Ironically, $\S 2339 \mathrm{D}$ carries a maximum sentence of ten years, while $\S$ 2339B and $\S 2339 \mathrm{C}$ carry maximum sentences of fifteen and twenty years, respectively. Thus, under existing law, the fundraiser actually faces worse potential penalties than the trained, violent operative awaiting instructions on when to strike.

${ }^{91}$ See Chesney, supra note 11, at 427-29, 437-46, 471-73; see also Chesney, supra note 47 , at $72-74$ (describing problems in prosecuting terrorists unaffiliated with any specific group using statutes drafted with international terrorist organizations in mind).

${ }_{92}$ See supra note 23 and accompanying text.

${ }^{93}$ See Chesney, supra note 11 , at 426 n.4, 435 \& n.34, 458.

${ }^{94}$ See supra notes $48-51$ and accompanying text. The military-type training offense also requires an affiliation with an FTO. See 18 U.S.C. $\S 2339 D$ (2006). The financing offense does not rely on the FTO designations, but its coverage is acts of international, not domestic, terrorism. See id. $\S 2339 \mathrm{C}(\mathrm{a})-(\mathrm{b})$. 
affiliation with an FTO, therefore, is not covered by the offense; accordingly, only persons who affirmatively conspire with them can be convicted of a crime. This differential between FTOs and unaffiliated, homegrown terrorist groups may well be justified, ${ }^{95}$ but it illustrates the complexities in addressing the full nature of the terrorist threat.

Thus, existing U.S. federal criminal law provides extensive liability for those involved in terrorist attacks and the activities of terrorist organizations. In many cases, imposing liability will be easy and uncontroversial, as matters of both legal interpretation and factual proof. In other situations, however, the application of the offenses and theories of liability is more complicated. Particularly in cases involving charges of conspiracy, the inchoate aspect of the offense combined with the expansive reach of vicarious liability creates the potential for a terrorism indictment with an extensive scope.

Yet there are few legal principles to constrain the Government's charging decisions. Sometimes those outer limits can be avoided by charging a facilitation offense rather than conspiracy, but the most significant penalties will depend on vicarious liability. Thus, confronting the complexities in the criminal law of antiterrorism is unavoidable.

\section{APPLICABILITY OF THE INTERNATIONAL LAWS OF WAR}

In contrast to U.S. federal criminal law, the applicability of the international laws of war to transnational terrorist organizations and individual (alleged) terrorists is substantially less well defined. ${ }^{96}$ There is considerable disagreement among scholars, judges, lawyers, and government officials about when, how, or even if the laws of war apply to antiterrorism efforts.

This is unsurprising, however, because all sides in those disagreements can find common ground on a simple premise: the current treaties embodying the international laws of war were devised with many problems and issues in mind, but the threat of transnational terrorist organizations, as such, was not one of them. Therefore, everyone agrees that the application of the existing international laws of war to terrorism will involve interpretive difficulties. The principal disputed questions concern how much of the international laws of war should be deemed to apply to terrorism, and how much remains outside their scope. The answers are contested and unclear, and some remain unresolved.

${ }^{95}$ For example, there would be substantial First Amendment freedom of association objections to the creation of a "domestic terrorist organization" list.

96 Some scholars and commentators prefer the newer label "international humanitarian law" for the body of international law which governs the conduct of hostilities in wars and other armed conflicts. See Robert Sloane, Prologue to a Voluntarist War Convention, $106 \mathrm{MiCH}$. L. REV. 443, 445 (2007) (describing the origins and implications of the labels). Because of my focus on comparing, contrasting, and analyzing the interactions between this body of law and the alternative criminal law model, I prefer the older label "laws of war." 
Nonetheless, the debates about the applicability of the laws of war illustrate the insights and significance of a military model, grounded in principles of international law, for dealing with terrorists - an alternative to the criminal law model under domestic, civilian law. Although the international laws of war on their own terms may not directly resolve all the necessary issues, they provide an important conceptual framework for assessing how new U.S. and international law can, and should, be designed to address the threat of al Qaeda and other transnational terrorist organizations.

\section{A. The Basics}

Historically, the international laws of war applied only to wars between the Governments of recognized states. ${ }^{97}$ All other military conflicts, like civil wars or secessionist movements, fell outside the scope of the laws of war. ${ }^{98}$ State sovereignty was preeminent, and international law did not reach into the internal affairs of a country - even when the fighting taking place on the ground involved exactly the same kinds of military engagements and danger to civilians as a traditional state-against-state war. ${ }^{99}$ If the parties to the hostilities were not two states, the laws of war simply did not apply. The experiences of the twentieth century led to an expansion of international law to reach other kinds of armed conflict which closely resembled war but did not fit the traditional formalistic requirement of two opposing state parties. In particular, the Spanish Civil War in the 1930s and armed resistance during World War II to Nazi occupations and their collaborationist governments illustrated the inadequacies of the traditional model. ${ }^{100}$ These circumstances inspired the adoption of provisions in the 1949 Geneva Conventions applicable to those intrastate armed conflicts which were functionally comparable to interstate war. ${ }^{101}$ Subsequent conflicts involving

${ }^{97}$ See Nathaniel Berman, Privileging Combat? Contemporary Conflict and the Legal Constructions of War, 43 COLUM. J. TRANSNAT'L L. 1, 15-23 (2004); Eric Talbot Jensen, Combatant Status: It Is Time for Intermediate Levels of Recognition for Partial Compliance, 46 VA. J. INT'L L. 209, 214-18 (2005); Derek Jinks, The Applicability of the Geneva Conventions to the "Global War on Terrorism," 46 VA. J. INT'L L. 165, 166-68 (2005).

98 See LindSAY MOIR, THE LAW OF INTERNAL ARMED CONFLICT 1-23 (2002); Derek Jinks, September 11 and the Laws of War, 28 YALE J. INT'L L. 1, 14-15 (2003).

${ }_{99}$ See Berman, supra note 97 , at 24-31.

${ }^{100}$ See MoIR, supra note 98, at 19-21; Berman, supra note 97, at 18; Jinks, supra note 97, at 167, 189 n.45 (noting that "the Spanish Civil War [was the] the historical case most often referenced in the [Geneva] Conventions drafting process as proof that international regulation of 'internal' conflict was necessary").

${ }^{101}$ See Jinks, supra note 98, at 14-18, 39 (noting that between the coverage provided by Common Article 2 and Common Article 3, the Geneva Conventions were intended to apply to all hostilities, whether transnational or intra-state, which qualified as "armed conflicts"). The 1949 Geneva Conventions are comprised of four treaties on related 
colonies pursuing independence from European rule reaffirmed the need for the international laws of war to cover some forms of intrastate armed conflicts. ${ }^{102}$

Yet the international laws governing interstate war were not simply applied wholesale to intrastate conflicts. Rather, a dual regime was created, which provided extensive, detailed provisions for international war and a few, simple, minimal protections for noninternational war. ${ }^{103}$ This system arose because sovereignty was no longer viewed as exclusively preeminent, nor was it viewed as entirely obsolete. Two wars might involve exactly the same kinds of hostilities, but different interests might be implicated depending on the context. In an international war, both states have aligned interests in using international law to ensure reciprocity of obligations. ${ }^{104}$ In noninternational war, by contrast, a tension exists between the humanitarian objectives of international law, on the one hand, and the state's sovereign power to manage its own internal affairs, on the other. ${ }^{105}$ Expansive application of the international laws of war to noninternational conflicts would threaten to erode state sovereignty. Thus, although the traditional formalistic

subjects. The First and Second Geneva Conventions address the treatment of sick and wounded members of ground and naval forces, respectively. See Geneva Convention for the Amelioration of the Condition of the Wounded and Sick in Armed Forces in the Field, Aug. 12, 1949, 6 U.S.T. 3114, 75 U.N.T.S. 31, art. 3; Geneva Convention for the Amelioration of the Condition of Wounded, Sick and Shipwrecked Members of Armed Forces at Sea, Aug. 12, 1949, 6 U.S.T. 3217, 75 U.N.T.S. 85, art. 3. The Third Convention concerns the treatment of prisoners of war, and the Fourth concerns the treatment of civilians and other protected persons. See Geneva Convention Relative to the Treatment of Prisoners of War, Aug. 12, 1949, 6 U.S.T. 3316, 75 U.N.T.S. 135, art. 3 [hereinafter GCPW]; Geneva Convention Relative to the Protection of Civilian Persons in Time of War, Aug. 12, 1949, 6 U.S.T. 3516, 75 U.N.T.S. 287, art. 3 [hereinafter GCCP].

${ }^{102}$ Wars seeking self-determination, independence from colonial rule, and other socalled "wars of national liberation" were the primary impetus for the addition of Protocols I and II to the Geneva Conventions in 1977. See Berman, supra note 97, at 24-31; Catherine Bloom, The Classification of Hezbollah in Both International and Non-International Armed Conflicts, 14 ANN. SuRV. INT'L \& COMP. L. 61, 70 (2008); Derek Jinks, The Declining Significance of POW Status, 45 HARV. INT'L L.J. 367, 409 \& n.255, 412 (2004); see also Protocol Additional to the Geneva Conventions of Aug. 12, 1949, and Relating to the Protection of Victims of International Armed Conflicts, Dec. 12, 1977, 1125 U.N.T.S. 3, art. 1, para. 4 [hereinafter Protocol I] (stating that Protocol I applies to "armed conflicts in which peoples are fighting against colonial domination and alien occupation and against racist regimes in the exercise of their right of self-determination"); Protocol Additional to the Geneva Conventions of 12 August 1949, and Relating to the Protection of Victims of Non-International Armed Conflicts, Dec. 12, 1977, 1125 U.N.T.S. 609, art. 1 [hereinafter Protocol II] (stating that Protocol II applies to "all armed conflicts which are not covered by Article 1 of [Protocol I] and which take place in the territory of a High Contracting Party between its armed forces and dissident armed forces").

${ }^{103}$ This point is elaborated in greater detail infra Parts III.A.1 (international) and Part III.A.2 (non-international).

${ }^{104}$ See Jinks, supra note 97 , at 190-95.

${ }^{105}$ See Berman, supra note 97, at 32-33; Jensen, supra note 97, at 224-26. 
distinction between international and noninternational war no longer determines the applicability of any international law, it continues to be a decisive factor in determining which, and consequently how much, international law applies under the Geneva Conventions framework.

Today, in the aggregate, the international laws of war regulate military and paramilitary violence involving formal and informal armed forces in conflicts between or within nation-states. Even this relatively broad conceptual framework, however, does not neatly encompass the threat posed by al Qaeda and similar terrorist groups. Thus, applying the existing laws of war to transnational terrorist organizations is pragmatically and conceptually problematic. At the same time, the laws of war provide an important starting point for assessing terrorism as a military, rather than criminal, threat.

\section{Combatants, Noncombatants, and War Criminals}

In either type of conflict, international or noninternational, the classification of persons as combatants or as noncombatants is fundamental to the existing laws of war. ${ }^{106}$ Most significantly, the classification has important effects in three principal areas: targeting by military force, authority for detention, and exposure to punishment. Whether a person is a combatant or a noncombatant is perhaps the most critical determination in assessing his or her rights, protections, and fate under the laws of war.

First, combatants may be targeted by military force in the hostilities but noncombatants may not. ${ }^{107}$ Combatants are personally involved in the fighting,

${ }^{106}$ See MoIR, supra note 98 , at 139, 144-49, 150-53, 156-60 (noting that protections for civilians apply in non-international armed conflicts, and further noting that regulations on methods of war and prohibitions on crimes against humanity and war crimes apply in non-international armed conflicts); Fionnuala Ní Aoláin, Hamdan and Common Article 3: Did the Supreme Court Get It Right?, 91 MINN. L. REV. 1523, 1527 (2007) ("Significantly, it does not formally address the status of combatants at all-the term does not arise in the language of Common Article 3. Nonetheless, Common Article 3 necessarily presumes the existence of combatants, because by protecting civilians, the article explicitly affirms the existence of hostilities, which inevitably draws attention to the legal status of those persons engaged in violence."); see also Jensen, supra note 97, at 218-29, 248 (explaining the efforts to distinguish lawful and unlawful combatants after the experience of World War II); Jinks, supra note 102, at 379, 437; Derek Jinks, Protective Parity and the Laws of War, 79 NOTRE DAME L. REV. 1493, 1497-99, 1524 (2004) (noting that, historically, postcapture protection was only extended to non-combatants and lawful combatants); Kenneth Watkin, Warriors Without Rights? Combatants, Unprivileged Belligerents, and the Struggle over Legitimacy 1-8 (Harvard Univ., Program on Humanitarian Policy and Conflict Research, Occasional Paper No. 2, 2005), available at www.hpcr.org /pdfs/OccasionalPaper2.pdf (describing the difficulty in classifying the September 11th attacks within the traditional paradigm of armed conflict).

${ }^{107}$ See generally INGRID DETTER, THE LAW OF WAR 132-50, 276-87 (2d ed. 2000) (noting the importance of distinguishing between civilians and combatants to ensure only 
making them legitimate military targets in the conflict. ${ }^{108}$ For example, military bases, troop convoys, and ammunition depots are legitimate military targets. ${ }^{109}$ By contrast, noncombatants may not be targeted for military attack. ${ }^{10}$ In fact, intentional attack against noncombatants constitutes a war crime. ${ }^{111}$ But not all harm to noncombatants is automatically a violation of the laws of war-some detriment to noncombatants is inevitable during armed conflict. The doctrine of "collateral damage" recognizes this eventuality and provides that when noncombatant casualties occur as incidental effects of legitimate combatant activities, no violation of the laws of war takes place. ${ }^{112}$ For example, civilians killed when a munitions factory is bombed and destroyed are collateral damage. ${ }^{113}$ Thus, the classification of persons as combatants or noncombatants plays a significant role in the execution of military operations in the conflict.

Second, combatants may be detained with far greater authority than noncombatants. As will be discussed below, the details of the applicable detention rules vary between international and noninternational conflicts, the basic underlying reason for the classification remains the same. Combatants, even those who have surrendered or been captured, pose a significant continuing threat to their enemy; accordingly, they may be detained to incapacitate them from further participation in hostilities. Noncombatants, by contrast, are by definition not

combatants are targeted); YoRAM DinsteIn, THE CONDUCT OF HOSTILITIES UNDER THE LAW OF INTERNATIONAL ARMED CONFLICT 27-29, 87-99 (2004) (noting that "[1]awful combatants can attack enemy combatants or military objectives . . . but . . . civilians enjoy general protection against dangers arising from military operations"); LESLIE C. GREEN, THE CONTEMPORARY LAW OF ARMED CONFLICT 122-25 (2d ed. 2000) (discussing targeting rules applicable to the conduct of hostilities); Kenneth Watkin, Controlling the Use of Force: A Role for Human Rights Norms in Contemporary Armed Conflict, 98 AM. J. INT'L. L. 1, 14-17 (2004) (noting that the "use of force must be controlled to ensure that is it used intentionally only against valid military objectives").

${ }^{108}$ See GREEN, supra note 107 , at 122-25; Watkin, supra note 107 , at 16 ("[P]ersons taking a direct part in hostilities are subject to being lawfully targeted by the opposing force.").

${ }^{109}$ See DINSTEIN, supra note 107, at 27-29.

${ }^{110}$ See id. at 87-94; GREEN, supra note 107, at 155-57, 159-61, 190-93; Watkin, supra note 107, at 15 ("Although thirty countries have not ratified Additional Protocol I, the targeting provisions are largely seen as reflective of customary international law ... [including] the strict limitation of attacks to "military objectives."').

111 DINSTEIN, supra note 107, at 230-32; see also GCCP, supra note 101, art. 146 (providing that state parties must enact legislation imposing penal sanctions for violating any provision of the GCCP); Protocol I, supra note 102, arts. 51(2), 52(1) (prohibiting civilian populations and "civilian objects" as "object[s] of attack or of reprisals").

${ }_{112}$ See DINSTEIN, supra note 107, at 123-25; Watkin, supra note 107, at 16 . Moreover, using noncombatants as "human shields" for a military target is a violation by the side exploiting its own civilians, not by the side which legitimately attacks the target. See DINSTEIN, supra note 107, at 129-31.

${ }^{113}$ See GREEN, supra note 107 , at 49 n. 186. 
participating directly in hostilities and therefore should not be detained except when necessary.

Third, only certain combatants may be prosecuted and punished for their participation in the conflict. Again, the details vary between international and noninternational conflicts and will be discussed below, but the underlying rationale is identical. Persons who qualify as privileged combatants possess a legal immunity, but persons who are unprivileged combatants lack immunity and therefore may be prosecuted and punished for their mere participation in hostilities.

The classification of a person as a noncombatant is profound, but it is not immutable. It is possible, of course, for someone who might previously have been a noncombatant to become a combatant. For example, enlisting in the regular armed forces or a militia turns the individual into a combatant, as does joining a spontaneous uprising against invading forces. ${ }^{114}$

On the other hand, rendering aid to the soldiers of one's country, without personally taking up arms or actively assisting in the conduct of hostilities, does not make one a combatant. For example, citizens who provide food or shelter to soldiers, or who otherwise support the overall war effort, remain noncombatants. ${ }^{115}$ Significantly, the laws of war do not recognize inchoate or vicarious combatant status; either an individual is himself a combatant or he is not. ${ }^{116}$ Only personally taking up arms, as part of a formal or informal armed force, changes a noncombatant's status into a combatant in the armed conflict. ${ }^{117}$

${ }^{114}$ See GCPW, supra note 101, art. 4(A).

${ }^{115}$ See Watkin, supra note 107 , at 16 ("Civilians such as industrial workers have often prompted moral questions concerning their degree of contribution to the war effort. Additional Protocol I specifically protects them from intentional attack "unless and for such time as they take a direct part in hostilities." (quoting Protocol I, supra note 102, art. 51(3))); see also DINSTEIN, supra note 107, at 27-28 (noting that "a mere contribution to the general warfare effort (e.g., by supplying foodstuffs to combatants) is not tantamount to active participation in hostilities").

${ }^{116}$ See Watkins, supra note 107, at 16-17.

${ }^{117}$ See, e.g., Jinks, supra note 106, at 1497 ("Noncombatants are granted immunity from attack so long as they do not participate directly in the hostilities."); Watkin, supra note 106, at 9-11, 32 (stating that direct participation in hostilities eliminates civilian status); Watkin, supra note 107, at 15 (noting that "the fundamental tenet of the obligation to distinguish between persons who take part in hostilities and those who do not"); see also GCPW, supra note 101, art. 3 (protecting, inter alia, "[p]ersons taking no active part in the hostilities"). The Fourth Convention also emphasizes personal involvement in hostilities. See GCCP, supra note 101, art. 5 (declaring that, if "an individual protected person is definitely suspected of or engaged in activities hostile to the security of the State," such a person is not entitled to certain rights and privileges); Jinks, supra note 102, at 389 ("Derogation [under GCCP Article 5] therefore requires that the detaining state know or have good reason to suspect that a particular individual has engaged in hostile acts. This requirement, in general, poses no great difficulty in the case of unlawful combatants, who, by definition, have directly participated in hostilities against the detaining state." (citation omitted)). 
Despite the importance of the combatant/noncombatant classification decision, however, the Geneva Conventions sometimes fail to specify which provisions are intended to apply in which scenarios, leading to disagreements over their application. The most prominent example of this is the dispute over which provisions, and accordingly which protections, apply to "unlawful combatants" who have failed to comply with the laws of war. Notwithstanding some interpretive difficulties, the classification remains crucial to the existing laws of war.

Finally, persons involved in the commission of war crimes may be prosecuted and punished for their conduct in violation of the laws of war regardless of their otherwise applicable status. Combatants who commit war crimes during hostilities are culpable; so too are noncombatants who order or otherwise participate in their commission. ${ }^{118}$ Furthermore, unlike the determination of combatant status, the liability rules for war crimes are significantly broader than direct, personal participation in the actual act of commission. For instance, under the doctrine of "command responsibility," military officers are accountable for the war crimes committed by their subordinates, including ones the officer did not personally order or direct. ${ }^{119}$ In addition, persons who aid and abet the commission of war crimes by personally providing some direct, substantial assistance to the actual perpetrators are vicariously liable. ${ }^{120}$ Vicarious liability also is available under the international criminal law doctrine of "joint criminal enterprise," which in some circumstances may impose liability for additional, foreseeable war crimes committed in furtherance of the commission of other war crimes. ${ }^{121}$ By contrast, international war crimes law does not recognize inchoate liability for attempted war crimes; only completed war crimes may be prosecuted. ${ }^{122}$ Likewise, international law does not recognize liability to the full extent of U.S. conspiracy law's inchoate-offense and expansive Pinkerton vicarious liability. ${ }^{123}$

118 See Mark David Maxwell \& Sean M. Watts, "Unlawful Enemy Combatant": Status, Theory or Culpability, or Neither?, 5 J. INT'L CRIM. JUST. 19, 21 (2007).

${ }^{119}$ See DINSTEIN, supra note 107, at 237-43; GREEN, supra note 107, at 280-81, 30304 (noting that a commander is vicariously liable because a commander may delegate authority to act, but may not delegate responsibility); Allison Marston Danner \& Jenny S. Martinez, Guilty Associations: Joint Criminal Enterprise, Command Responsibility, and the Development of International Criminal Law, 93 CAL. L. REV. 75, 120-31 (2005).

${ }^{120}$ See Danner \& Martinez, supra note 119, at 102, 120, 141; Joseph Rikhof, Complicity in International Criminal Law and Canadian Refugee Law, 4 J. INT'L CRIM. JUST. 702, 704-07 (2006).

${ }^{121}$ Danner \& Martinez, supra note 119, at 103-20; Rikhof, supra note 120 , at 708 09; see also Prosecutor v. Tadić, Case No. IT-94-1-A, Judgment, ICTY Appeals Chamber, paras. 190, 220-228 (Jul. 15, 1999) (noting that individuals acting in accordance with a common plan, design, or purpose are responsible for ensuing criminal conduct).

${ }^{122}$ See Danner \& Martinez, supra note 119, at 118-19.

${ }^{123}$ See Brief of Amici Curiae Specialists in Conspiracy and International Law at 7-8, 19-21, Hamdan v. Rumsfeld, 548 U.S. 557 (2006) (No. 05-184); Danner \& Martinez, 
Thus, the laws of war mark a sharp distinction between the definition of combatant status, which depends on some form of direct personal participation in hostilities, and responsibility for the commission of war crimes, which imputes liability for some forms of indirect involvement. It may be important, then, to determine which is the relevant status in a given situation: combatant, noncombatant, or war criminal.

\section{International Armed Conflicts}

A substantial body of the international laws of war-in particular the four Geneva Conventions, most famously the Third, which addresses prisoners of war-applies to the treatment of persons involved in and affected by international armed conflicts. ${ }^{124}$ Under the Conventions, international armed conflicts include all "armed conflicts" between states, regardless of whether they are declared wars in the traditional sense, have some other status under domestic law, or even when one side refuses to legally recognize the conflict. ${ }^{125}$ The Conventions define various categories of persons who are subject to protection under various provisions, and delineate the obligations the state parties to the conflict owe to them.

supra note 119, at 118-19; George P. Fletcher, Hamdan Confronts the Military Commissions Act of 2006, 45 ColuM. J. TRANSNAT'L L. 427, 440-55 (2007); see also Hamdan, 548 U.S. at 598-613 (Stevens, J., plurality opinion) ("In sum, the sources that the Government and Justice Thomas rely upon to show that conspiracy to violate the law of war is itself a violation of the law of war in fact demonstrate quite the opposite."). Some critics fear that the scope of joint criminal enterprise liability in international criminal law is becoming not so different from Pinkerton. See, e.g., Danner \& Martinez, supra note 119, at 136-37; Mark Osiel, The Banality of Good: Aligning Incentives Against Mass Atrocity, 105 COLUM. L. REV. 1751, 1796-1800 (2005).

${ }^{124}$ See supra note 101 (citing the four Geneva Conventions). See generally DETTER, supra note 107 , at 17-20, 25-26 (discussing general principles of the law of armed conflict). In litigation arising from the war on terror, U.S. courts have focused on the provisions of the Third Convention. See, e.g., Hamdan, 548 U.S. at 618-19; Hamdi v. Rumsfeld, 542 U.S. 507, 515 (2004); United States v. Lindh, 212 F. Supp. 2d 541, 553 (E.D. Va. 2002).

${ }^{125}$ See GCPW, supra note 101, art. 2, para. 1 (stating that "the present Convention shall apply to all cases of declared war or of any other armed conflict which may arise between two or more of the High Contracting Parties, even if the state of war is not recognized by one of them"). Technically, of course, the Convention only applies to signatories. See $i d$. (referring to its application to conflicts "between two or more of the High Contracting Parties"). Nonetheless, signatories always are bound to apply the Convention among themselves, even if third parties to an armed conflict are not signatories; they likewise are bound to apply the Convention "in relation to" any nonsignatory state that "accepts and applies the provisions thereof" in the conflict. See id. art. 2, para. 3. Common Article 2 is identical in all four Geneva Conventions. See supra note 124 and accompanying text. 
The Third Convention covers a large and significant class of protected persons: prisoners of war. The basic structure of the Convention's application is straightforward: persons who are combatants in international armed conflicts are obliged to comply with certain rules of war, and in return they receive certain protections as "prisoners of war" upon surrender or capture. ${ }^{126}$ Persons who qualify as POWs also are referred to as "lawful combatants" or the older moniker "privileged belligerents," although the Convention itself does not use those labels. $^{127}$

Lawful combatants must comply with several important obligations. First, they must obey the "principle of distinction," which requires that combatants be clearly distinguishable from noncombatants to enable opposing forces to readily and correctly identify legitimate targets and avoid improper ones. ${ }^{128}$ To ensure distinction, combatants must wear distinctive uniforms or emblems, and they must bear arms openly. ${ }^{129}$ Second, lawful combatants must conform their operations in hostilities to the laws of war and follow principles of command responsibility to ensure accountability for compliance and noncompliance. ${ }^{130}$ These four obligations apply not only to members of the regular armed forces of a state, but also to

${ }^{126}$ See id. art. 4(A) ("Prisoners of war, in the sense of the present Convention, are persons belonging to one of the following categories, who have fallen into the power of the enemy ...."). See generally DETTER, supra note 107, at 148-50, 326-36 (discussing the legal effects of combatant status and prisoner of war status); DINSTEIN, supra note 107, at 29-33 (discussing lawful and unlawful combatants); GREEN, supra note 107, at 196-215 (reviewing the application of the Conventions to prisoners of war); HILAIRE MCCOUBREY, INTERNATIONAL HUMANITARIAN LAW: THE REgULATION OF ARMED CONFLICTS 80-108 (1990) (discussing the protection of prisoners of war).

${ }^{127}$ See DINSTEIN, supra note 107, at 29-33 (noting the labels); GREEN, supra note 107 , at 102-09, 117-18 (noting the labels). The converse labels for unprotected parties are "unlawful combatant" and "unprivileged combatant." See Berman, supra note 97, at 13-15 (referring to the "unprivileged combatant" label as "the more correct form"); Jinks, supra note 102, at 379 (noting the labels); Watkin, supra note 106, at 12-13 (noting the labels).

${ }^{128}$ See DETTER, supra note 107, at 136; Jinks, supra note 102, at 379 (discussing the "rule of distinction"); Watkin, supra note 106, at 8-11, 29-33 (discussing the "principle of distinction"). Given its fundamental importance, weakening the principle of distinction "would risk unraveling the fabric of international humanitarian law." Jinks, supra note 106, at 1524; see also EDWARD KWAKWA, THE INTERNATIONAL LAW OF ARMED CONFLICT: Personal aNd MATERIal Fields OF AppliCATION $39-42$ (1992) (explaining that the principle of distinction has acquired the status of customary international law).

${ }^{129}$ See GCPW, supra note 101, art. 4(A)(2)(b) ("fixed distinctive sign recognizable at a distance"); $i d$. art. 4(A)(2)(c) ("carrying arms openly"); DINSTEIN, supra note 107, at 3739 ("fixed distinct emblem[s] recognizable at a distance").

${ }^{130}$ See GCPW, supra note 101, art. 4(A)(2)(a) ("being commanded by a person responsible for his subordinates"); $i d$. art. $4(\mathrm{~A})(2)(\mathrm{d})$ ("conducting their operations in accordance with the laws and customs of war"); see also Watkin, supra note 106, at 25-37 (discussing command responsibility principle and compliance requirement). 
irregular forces, militias, and organized resistance movements. ${ }^{131}$ Similar requirements apply to members of a spontaneous armed resistance against invading troops. ${ }^{132}$

Combatants who comply with these requirements are entitled, upon capture by the enemy, to treatment as prisoners of war under the Third Convention. ${ }^{133}$ Among other protections, POWs must receive humane treatment during detention and cannot be interrogated for military intelligence. ${ }^{134}$ POWs must also be repatriated when the conflict ends. ${ }^{135}$ In addition, POWs receive "combatant immunity," which protects them from prosecution or punishment in military or civilian proceedings for their mere participation in the armed conflict. ${ }^{136}$ POWs

${ }^{131}$ See GCPW, supra note 101, art. 4(A)(1)-(2). The text of the Third Convention explicitly lists the four requirements as applicable to irregulars in Article 4(A)(2), but does not list them in Article 4(A)(1) regarding regular armed forces. See Jinks, supra note 102, at 372-73 n.24. Accordingly, it is unclear whether members of regular armed forces must comply with the four requirements to obtain POW status. See id. at 372-73 n.24 ("As the current POW controversy illustrates, states and commentators take divergent views on this question."). Some commentators and international lawyers argue that the Convention drafters intended the requirements not to apply to regular armed forces, who would be protected as POWs even if they did not meet the requirements. See Berman, supra note 97, at 41-42 (discussing this interpretation); Robert M. Chesney, Leaving Guantánamo: The Law of International Detainee Transfers, 40 U. RICH. L. REV. 657, 718-28 (2006) (discussing the "implicit inclusion" interpretation of Article 4). Others assert that regular armed forces inherently meet the four requirements, so that it was necessary to list the requirement only for kinds of forces that would not inherently meet them. See Berman, supra note 97, at 42-43 (discussing this interpretation); see also DINSTEIN, supra note 107, at 36 (noting interpretation controversy). It is difficult to reach a conclusive interpretation of the intended meaning of Article 4 because the underlying policies justifying the definitions of lawful combatant status point in conflicting directions. See Berman, supra note 97, at 43-50 (noting various interpretations of Article 4); see also Watkin, supra note 106 , at 20-23 (discussing the historical origins of the four criteria as a compromise between the military capabilities and interests of powerful states and weaker states).

132 See GCPW, supra note 101, art. 4(A)(6) (stating that insurgents who "spontaneously take up arms to resist invading forces, without having had time to form themselves into regular armed units" which have uniforms and command responsibility are nonetheless required to bear arms openly and comply with the rules of war).

${ }^{133}$ See id. arts. $12-125$ (protecting prisoners of war); DINSTEIN, supra note 107, at 43-44 (noting that both the group to which the individual belongs, and the individual personally, must satisfy the requirements for lawful combatant status).

${ }^{134}$ See GCPW, supra note 101, art. 13 (humane treatment); id. art. 17 (limits on interrogation).

${ }^{135}$ See id. arts. $117-118$.

136 Jinks, supra note 102, at 376 n.38 ("This privilege is, as a formal matter, extraconventional in that the Geneva Conventions do not expressly accord any such privilege. It is nevertheless universally recognized."); see also DINSTEIN, supra note 107, at 31 (discussing combatant immunity); Berman, supra note 97, at 9-15 (same); Jinks, supra note 102, at 436-37 (same); Jinks, supra note 106, at 1500, 1502 n.21, 1520-21 (same). If 
may be prosecuted, however, for war crimes committed during the course of hostilities in the same manner and by the same courts-martial as the detaining country would use to prosecute and punish its own soldiers for the same offenses. ${ }^{137}$

Not all participants in an international armed conflict will comply with the Convention's obligations. Such "unlawful combatants" or "unprivileged belligerents" Convention. ${ }^{139}$ For example, the war fought in Afghanistan in 2001-2002 between the United States and the Taliban regime was an international armed conflict. ${ }^{140}$ The Taliban's armed forces failed to meet the requirements of the Geneva Conventions, at least in part because they did not wear distinctive emblems or uniforms. ${ }^{141}$ Accordingly, the Bush Administration maintained that captured Taliban soldiers were categorically not combatants entitled to POW status. ${ }^{142}$

If a captured soldier's compliance with the Third Convention's requirements is disputed, the Convention requires that he be given the protections of POW status until a "competent tribunal" determines his status one way or the other. ${ }^{143}$ Although the Bush Administration initially argued that no such tribunals were necessary because Taliban soldiers could not possibly dispute their noncompliance with the Convention requirements, military review boards ultimately were convened to determine the status of the detainees at Guantanamo Bay. ${ }^{144}$

POWs commit crimes while detained, they may be prosecuted and punished for those offenses by court-martial. See GCPW, supra note 101, arts. 82-108.

${ }^{137}$ See GCPW, supra note 101, arts. 82, 84, 99.

${ }^{138}$ See supra note 127.

139 See DETTER, supra note 107, at 141, 148; DINSTEIN, supra note 107, at 31-33; GREEN, supra note 107, at 105-09, 118; Berman, supra note 97, at 13-15; Jinks, supra note 102, at 378-79; Jinks, supra note 106, at 1506, 1518-19; Watkin, supra note 106, at 45-67.

${ }^{140}$ See Hamdan v. Rumsfeld, 548 U.S. 547, 628-29 \& n.60 (2006) (noting that U.S. conflict with the Taliban was an international armed conflict); see also DINSTEIN, supra note 107, at 47-50 (discussing applicability of GCPW to Taliban and al Qaeda in the Afghanistan conflict).

${ }^{141}$ See, e.g., United States v. Lindh, 212 F. Supp. 2d 541, 557-58 (E.D. Va. 2002) (concluding that the Taliban did not bear arms openly, lacked command responsibility, and failed to comply with the rules of war); DINSTEIN, supra note 107, at 47-48 (emphasizing that Taliban forces did not wear uniforms or emblems).

${ }^{142}$ See Brett Shumate, New Rules for a New War: The Applicability of the Geneva Conventions to Al-Qaeda and Taliban Detainees Captured in Afghanistan, N.Y. INT'L L. REV., Summer 2005, at 4-10, 28-42 (discussing Bush Administration interpretations of the Geneva Conventions as applied to the conflict in Afghanistan with Taliban and al Qaeda forces).

${ }^{143}$ See GCPW, supra note 101, art. 5.

${ }^{144}$ See generally Norman Abrams, The Military Commissions Saga, 5 J. INT'L CRIM. JUST. 2, 4-9 (2007) (describing political and litigation history of challenges to Guantanamo detentions); Boumediene v. Bush, 476 F.3d 981, 984-86 (D.C. Cir. 2007) (summarizing 
If unlawful combatants are not entitled to the protections for POWs provided by the Third Convention, the question remains what protection, if any, they are eligible to receive under the international laws of war. Historically, the answer was none. ${ }^{145}$ In the past, unprivileged belligerents were at the mercy of their captors, and could be treated summarily. ${ }^{146}$ Some commentators and the Bush Administration argue that unlawful combatants remain unprotected under the Geneva Conventions, as well. ${ }^{147}$ Other commentators assert that, just as the Geneva Conventions for the first time extended the laws of war to some intrastate armed conflicts, they also inaugurated a new, more "human rights"-oriented regime, in which all persons involved in or affected by an armed conflict are covered by at least some provisions of at least one of the Conventions. ${ }^{148}$

Although the title of the Fourth Convention speaks in terms of the "Protection of Civilian Persons," its provisions sweep far wider than the colloquial meaning of civilian. Under the Fourth Convention, "persons protected" are defined to include "those who, at a given moment and in any manner whatsoever, find themselves, in case of a conflict or occupation, in the hands of" an enemy state, ${ }^{149}$ except

the litigation history of Guantanamo detention challenges), rev'd, Boumediene v. Bush, 128 S.Ct. 2229 (2008).

${ }^{145}$ See Berman, supra note 97, at 14 n.27; Jinks, supra note 102, at 368-70; Jinks, supra note 106, at 1498-99; Sean D. Murphy, Evolving Geneva Convention Paradigms in the "War on Terrorism": Applying the Core Rules to the Release of Persons Deemed "Unprivileged Combatants," 75 GEO. WASH. L. REV. 1105, 1108-13 (2007); Watkin, supra note 106, at 46-47; see also Ex parte Quirin, 317 U.S. 1 (1942) (permitting prosecution by military tribunal of German soldiers whose conduct violated the rules of war, making them unlawful combatants).

${ }^{146}$ See Berman, supra note 97, at 14 n.27; Jinks, supra note 102, at 368-70; Jinks, supra note 106, at 1498-99; Murphy, supra note 145, at 1108-13; Watkin, supra note 106, at 46-47; see also Quirin, 317 U.S. at 31, 48 (noting historical tradition of summary treatment); DETTER, supra note 107, at 148 (stating that " $[\mathrm{u}]$ nlawful combatants . . . are a legitimate target for any belligerent action [but] are not, if captured, entitled to any prisoner of war status. They are also personally responsible for any action they have taken and may thus be prosecuted and convicted for murder if they have killed an enemy soldier. They are often summarily tried and enjoy no protection under international law").

${ }^{147}$ See Jinks, supra note 106, at 1498-99 nn.9-10 (citing authorities); Shumate, supra note 142, at 28-42 (describing the Bush Administration's interpretation of the Geneva Conventions).

${ }^{148}$ See Jinks, supra note 106, at 1500 ("[T] 1949 Geneva Conventions - though they draw on many structural features of traditional law of war treaties - lay the foundations for the 'human rights' perspective that so clearly predominates in the 1977 Protocols (and other important developments in humanitarian law)."); see also DINSTEIN, supra note 107, at 32 (asserting that unlawful combatants are protected by the Fourth Convention); Watkin, supra note 106, at 50-54 (discussing protections of GCCP).

${ }^{149}$ GCCP, supra note 101 , art. 4 , para. 1 (emphasis added). 
"persons protected by the" First, Second, or Third Conventions. ${ }^{150}$ Accordingly, the text of the Fourth Convention appears to cover unlawful combatants, who fall into the category of persons not protected by the Third Convention. ${ }^{151}$ Moreover, the Fourth Convention specifically authorizes derogation from rights otherwise applicable under its terms ${ }^{152}$ for "an individual protected person [who] is definitely suspected of or engaged in activities hostile to the security of the" enemy state. ${ }^{153}$ This provision can be seen as an explicit reference to unlawful combatants, and an acknowledgement that their protection under the Fourth Convention justifiably is narrower than that given to noncombatants. ${ }^{154}$ Importantly, however, the Convention's protections for fair trials cannot be derogated, ${ }^{155}$ which would impose a significant restriction on the summary treatment of unlawful combatants. ${ }^{156}$

Thus, under this interpretation of the Fourth Convention, unlawful combatants receive some protections similar to those granted to POWs. ${ }^{157}$ Like POWs, unlawful combatants may be detained in military custody ${ }^{158}$ until they are repatriated when the conflict ends. ${ }^{159}$ Unlike POWs, however, unlawful combatants do not receive the protection of combatant immunity; therefore, they may be prosecuted and punished not only for war crimes, but also for ordinary

${ }^{150}$ Id. art. 4, para. 3 (emphasis added); see also GREEN, supra note 107, at 229-43 (discussing protections of GCCP).

${ }^{151}$ See Jinks, supra note 102, at 381-87; cf. Jason Callen, Unlawful Combatants and the Geneva Conventions, 44 VA. J. INT'L L. 1025, 1028-29 (2004) (agreeing that the Fourth Convention applies to unlawful combatants captured while operating in the home territory of the capturing belligerent state, but arguing, based on the Convention's text and its drafting history at the Geneva Conference, that it does not apply to "battlefield unlawful combatants" such as those detained by U.S. forces in Afghanistan or pre-occupation Iraq).

${ }^{152}$ Like the Third Convention, the Fourth Convention provides extensive protections for protected persons. See GCCP, supra note 101, arts. 13-141.

${ }^{153}$ Id. art. 5, para. 1. The derogation of Fourth Convention rights for such persons is limited to "such rights and privileges under the present Convention as would, if exercised in the favour of such individual person, be prejudicial to the security of such State." Id. In addition, "full rights and privileges of a protected person under the present Convention" must be restored "at the earliest date consistent with the security of the State." Id. para. 3.

${ }^{154}$ See Jinks, supra note 102, at 387-93; Watkin, supra note 106, at 50-54 (analyzing the scope of protection offered to unlawful combatants under the Fourth Convention).

${ }^{155}$ GCCP, supra note 101, art. 5, para. 3 ("[S]uch persons shall nevertheless be treated with humanity, and in case of trial, shall not be deprived of the rights of fair and regular trial prescribed by the present Convention ...."). Many of these rights, see $i d$. arts. 71-76, apply in trials taking place in the territory of the detaining country, see $i d$. art. 126.

${ }^{156}$ See Jinks, supra note 102, at 397-99, 404-09.

${ }^{157} I d$. at 405-09, 424; Watkin, supra note 106, at 51-52, 68; compare GCCP, supra note 101, arts. 5, 71-76 (trial rights under the Fourth Convention), with GCPW, supra note 101, arts. 105-108 (trial rights under the Third Convention).

${ }^{158}$ See Jinks, supra note 102 , at 418.

${ }^{159}$ See GCCP, supra note 101 , arts. 35-38, 77, 132-135. 
offenses like murder in connection with their mere participation in hostilities. ${ }^{160}$ Compared to lawful combatants, this is a substantial disadvantage.

Even if the Fourth Convention applies to unlawful combatants, however, its coverage is, like the Third Convention, limited to international armed conflicts between states. ${ }^{161}$ As a result, the Convention only applies to enemy nationalsthat is, nationals of opposing states in the armed conflict. ${ }^{162}$ The Convention does not apply to a state's own nationals, and it does not apply to nationals of allied or neutral states with which ordinary diplomatic relations exist. ${ }^{163}$

Another provision of the Geneva Conventions also may apply to unlawful combatants in an international armed conflict. As discussed in more detail below, Common Article 3 of the four Conventions applies to all persons detained in an armed conflict, including former combatants, and prohibits the imposition of punishment without a trial by a regular court with significant procedural fairness. ${ }^{164}$ Although its text would appear to indicate otherwise, the international law consensus is clear that Common Article 3 applies in international armed conflicts. ${ }^{165}$ Thus, even if captive unlawful combatants are not protected by the

${ }^{160}$ See DINSTEIN, supra note 107 , at $30-31$; Jinks, supra note 102 , at 422,437 ; Maxwell \& Watts, supra note 118, at 23-25; Watkin, supra note 106, at 49 (noting that engaging in hostilities as an unlawful combatant is not, by itself, a war crime, but persons who are unlawful combatants are unprotected by combatant immunity for prosecution for ordinary crimes arising from their activities during hostilities).

${ }^{161}$ See GCCP, supra note 101, art. 2, para. 1.

${ }^{162}$ See id. art. 4, para. 1 ("Persons protected by the Convention are those who ... find themselves, in case of a conflict ... in the hands of a Party to the conflict ... of which they are not nationals."). The Fourth Convention also applies to territory of an enemy state occupied by the invading state's military forces. Id. ("Persons protected by the Convention are those who... find themselves, in case of $\mathrm{a}[\mathrm{n}] \ldots$... occupation, in the hands of $\mathrm{a}[\mathrm{n}]$... Occupying Power of which they are not nationals.").

${ }^{163}$ See id. art. 4 para. 2 ("Nationals of a neutral State who find themselves in the territory of a belligerent State, and nationals of a co-belligerent State, shall not be regarded as protected persons while the State of which they are nationals has normal diplomatic representation in the State in whose hands they are."). The only exception is Articles 13 to 26 , pertaining primarily to access to medical treatment and facilities by the sick and wounded, which apply to all persons regardless of nationality. See id. art. 13.

${ }^{164}$ See infra notes 176-183 and accompanying text.

165 See Jinks, supra note 102, at 402-03 \& nn.195-206 (citing numerous international law sources); see also DINSTEIN, supra note 107, at 32-33 (asserting that unlawful combatants in international armed conflicts are protected by Common Article 3). In particular, Article 75 of the 1977 Additional Protocol I to the Geneva Conventions "clarifies that the protections codified in Common Article 3 apply, as a matter of positive international law, to all armed conflicts." Jinks, supra note 102, at 403 \& n.205. Although the United States has not ratified Protocol I, see Jinks, supra note 102, at 385 n.114, "the United States does not object to Article 75 of Additional Protocol I... [, and] indeed, the United States recognizes that these minimum protections are part of customary international law." Id. at 409 n.255. The provisions that the United States did object to 
overall provisions of the Fourth Convention, they are at least covered by Common Article 3 . $^{166}$

The laws of war provide a detailed set of rules for combatants and noncombatants involved in or affected by international armed conflicts. Combatants of both types, lawful and unlawful, are legitimate military targets during hostilities. ${ }^{167}$ During the fighting, the differential status makes no difference. Moreover, upon their surrender or capture, both lawful and unlawful combatants are subject to detention to incapacitate them from further participation in the conflict and are given significant protections by the Geneva Conventions. The distinction between the two groups arises in their susceptibility to prosecution and punishment. Lawful combatants have combatant immunity; therefore, they can be punished only for war crimes under regular courts-martial used against members of the detaining state's own forces. Unlawful combatants, by contrast, lack combatant immunity and may be tried not only for war crimes, but also for mere participation in hostilities. Finally, noncombatants may not be targeted by military force, and since they have by definition not participated in hostilities, they are not subject to prosecution for crimes relating to the hostilities other than war crimes. Enemy noncombatant nationals may be detained under military authority, subject to the strictures of the Fourth Convention. ${ }^{168}$

\section{Noninternational Armed Conflicts}

The international laws of war and the Geneva Conventions also provide rules for dealing with an "armed conflict not of an international character."169 Rather than involving cross-border armed conflicts between two states, such conflicts

were those provisions that expanded definitions of lawful combatant status in Article 44 of Protocol I. See id. at 385 n.114.

166 See Jinks, supra note 102, at 403-09 (discussing the application of Common Article 3's protections to unlawful combatants).

${ }^{167}$ See Watkin, supra note 107 , at 16 (emphasizing "the fact that persons taking a direct part in hostilities are subject to being lawfully targeted by the opposing force... [and that c]onsequently, the principle of distinction is perhaps more accurately described as distinguishing between combatants, legal or otherwise, and those civilians who do not take a direct part in hostilities").

${ }^{168}$ For example, noncombatants and other protected persons should be interned separately from prisoners of war. See GCCP, supra note 101, art. 84.

${ }^{169} \mathrm{GCPW}$, supra note 101, art. 3; see, e.g., Hamdan v. Rumsfeld, 548 U.S. 557, 63132 (2006) (discussing scope of Common Article 3). See generally DETTER, supra note 107, at 39-49 (analyzing international aspects of civil wars and internal wars); GREEN, supra note 107, at 317-35 (summarizing the traditional view and application of the Conventions to noninternational conflicts); Hilaire McCoubrey \& Nigel D. White, InTERnATIONAL LAW AND ARMED CONFLICT 317-27 (1992) (analyzing the application of Additional Protocol II and Common Article 3 to internal armed conflicts); MoIR, supra note 98, at 2367 (analyzing scope and applicability of Common Article 3). 
occur within the territory of one or more signatory states. ${ }^{170}$ Civil wars for control of a state's government and regional secessionist movements are classic examples of "armed conflicts not of international character." "171 Thus, by extending coverage to noninternational armed conflicts, the Geneva Conventions specifically contemplate the application of the international laws of war to some kinds of hostilities between a state on one side and nonstate actors on the other. ${ }^{172}$

As explained above, rather than simply transposing the rules applicable to international armed conflicts to noninternational ones, the states that drafted the Conventions deliberately chose to apply different, far narrower rules to such conflicts. ${ }^{173}$ The Third Convention's protections for lawful combatants do not apply in noninternational armed conflicts. ${ }^{174}$ The Fourth Convention's extensive protections for noncombatants and other protected persons are likewise inapplicable. ${ }^{175}$

A single provision of the Geneva Conventions, Common Article 3, applies to noninternational armed conflicts. ${ }^{176}$ Unlike the rules applicable to international

${ }^{170}$ See GCPW, supra note 101, art. 3 ("In the case of armed conflict not of an international character occurring in the territory of one of the High Contracting Parties...."). It is important to emphasize that this language in Common Article 3 is meant to provide jurisdiction for applying the Conventions' provisions in the first place (because, after all, only signatories to the Conventions are bound by their terms), not to limit the scope of Common Article 3's applicability to only certain types of noninternational conflicts. See Jinks, supra note 97, at 189 n.45 ("The actual purpose of this language, as the drafting history and subsequent commentary make clear, was to require a jurisdictional nexus between the conflict and a state party to the treaty. In other words, this clause should be understood to mean that the armed conflict must occur in the territory of at least one of the High Contracting Parties.") (citations omitted) (emphasis added); see also MoIR, supra note 98, at 31 (discussing this interpretation); Jinks, supra note 98, at 4041 (arguing that Common Article 3 should be interpreted to apply to "armed conflicts between a state and a foreign-based (or transnational) armed group or an internal armed conflict that spills over an international border into the territory of another state").

${ }^{171}$ See Jinks, supra note 97, at 188 (noting that civil wars were the "paradigmatic" situation of intra-state armed conflict covered by the Geneva Conventions).

${ }^{172}$ See id. at 182-89; Jinks, supra note 98, at 10-13, 39-41; see also Berman, supra note 97 , at $18-22,47-50$ (discussing the expansion of the international laws of war to include internal armed conflicts).

${ }^{173}$ See supra notes 100-105 and accompanying text; see also Ní Aoláin, supra note 106, at 1527-34 (discussing states' motivations for narrow applicability of Common Article 3); Jinks, supra note 102, at 401-02 (describing reasons for narrow applicability of Common Article 3 to internal armed conflicts).

${ }^{174}$ See GCPW, supra note 101, art. 2 ("[T] he present Convention shall apply to ..."); $i d$. art. 4 (protecting "[p]risoners of war, in the sense of the present Convention").

${ }^{175}$ See GCCP, supra note 101, art. 2 ("[T] he present Convention shall apply to ... "); id. art. 4 ("Persons protected by the [First, Second, or Third Conventions] shall not be considered as protected persons within the meaning of the present Convention.").

${ }^{176}$ See GCPW, supra note 101, art. 3; see also Hamdan v. Rumsfeld, 548 U.S. 557, 629-31(2006) (recognizing that Common Article 3 applies to noninternational armed 
armed conflicts, Common Article 3 does not expressly distinguish between lawful and unlawful combatants, or between combatants and noncombatants, in the protection it provides. Common Article 3 applies to all "[p]ersons taking no active part in the hostilities, including members of armed forces who have laid down their arms and those placed hors de combat by sickness, wounds, detention, or any other cause." 177 It protects persons who have remained noncombatants throughout the conflict, but it also "expressly covers persons who take up arms against the state and applies even to persons who do not lay down their arms voluntarily." Regardless of their prior activities, all such persons are entitled to humane treatment and nondiscrimination; they also are protected against violence and outrages to personal dignity such as murder, torture, and humiliating or degrading treatment. $^{179}$

Under Common Article 3, the distinction between lawful and unlawful combatants does not exist and none of the Third Convention's special protections for lawful combatants apply. ${ }^{180}$ Accordingly, combatant immunity also is inapplicable, and former combatants may be prosecuted and punished not only for any war crimes they committed, but also for their mere participation in hostilities. ${ }^{181}$ Just as unlawful combatants in international conflicts no longer may be treated summarily, Common Article 3 expressly includes a prohibition on "the passing of sentences and the carrying out of executions without previous judgment pronounced by a regularly constituted court affording all the judicial guarantees which are recognized as indispensable by civilized peoples." 182 Thus, all captured

conflicts). The provision is called "Common" Article 3 because it is repeated verbatim in each of the four Geneva Conventions on the laws of war. See Hamdan, 548 U.S. at 629.

${ }^{177}$ GCPW, supra note 101, art. 3(1); see also GREEN, supra note 107, at 44-45, 5960, 231, 325-29 (discussing specific applications of Common Article 3).

178 Jinks, supra note 106, at 1507 n.55.

${ }^{179}$ See GCPW, supra note 101, art. 3(1), (1)(a), (1)(c). Unlike the GCPW and GCCP, Common Article 3 "does not expressly include a right to release and repatriation at the close of hostilities." Jinks, supra note 102, at 423.

${ }^{180}$ See Berman, supra note 97, at 19-20; Jinks, supra note 98, at 11-14, 18; Watkin, supra note 106, at 3 \& n.9, 5; see also al-Marri v. Wright, 487 F.3d 160, 184-85 \& n.13 (4th Cir. 2007) (citing Int'l Comm. of the Red Cross, Official Statement: The Relevance of IHL in the Context of Terrorism, at 1, 3 (Feb. 21, 2005), available at http://www.icrc.org/web/eng/siteeng0.nsf/html/terrorism-ihl-210705).

${ }^{181}$ See DINSTEIN, supra note 107, at 30-31; Berman, supra note 97, at 20 ("States remain free, for example, to prosecute rebels in a 'non-international armed conflict' for murder and treason on the basis of mere participation in combat."); Jinks, supra note 98, at 18 n.118, 42-44; Jinks, supra note 102, at 403-06, 413; Murphy, supra note 145, at 1116; see also Watkin, supra note 106, at 65-67 (noting the difficulties of applying combatant status and the principle of distinction concepts to non-international armed conflicts).

${ }^{182} \mathrm{GCPW}$, supra note 101 , art. 3(1)(d). The content and extent of these indispensable judicial guarantees were significantly specified and elaborated in Article 75 of Additional Protocol I in 1977. See Murphy, supra note 145, at 1145-48 (discussing the scope and applicability of Protocol I art. 75). Although the U.S. has not ratified Protocol I, it has long 
former soldiers from a noninternational conflict cannot be punished without significant judicial process. ${ }^{183}$

The laws of war applicable to noninternational armed conflicts are similar to, but are considerably less detailed than, those for international armed conflicts. In either type of conflict, combatants are legitimate military targets during hostilities while noncombatants are not. Also like international conflicts, Common Article 3 contemplates the detention of both noncombatants and former combatants during the conflict. Other than a few minimal guarantees of fair treatment, however, Common Article 3 does not constrain the terms and conditions of detention with anything close to the specificity of the Third and Fourth Conventions. Unlike the law of international armed conflict, Common Article 3 does not provide for lawful combatant status or its protections, subjecting all combatants to the possibility of prosecution and punishment for their mere participation in hostilities-essentially making all former combatants in noninternational conflicts the equivalent of unlawful combatants in international conflicts. Like detention, Common Article 3 prescribes minimal standards for the judicial process used to prosecute and punish former combatants, but not with the scope of the provisions of the Third and Fourth Conventions.

\section{The Bush Administration and the Military Commissions Act of 2006}

Since shortly after the September 11th attacks, the Bush Administration has maintained that members of al Qaeda should be deemed unlawful combatants in an international armed conflict. ${ }^{184}$ Accordingly, the Administration claims that captured al Qaeda members are not protected by any provisions of the Geneva Conventions. $^{185}$

conceded that Article 75 has become customary international law. See id.; Jinks supra note 102 at 409 n. 255,431 n.359.

${ }^{183}$ See MOIR, supra note 98, at 203-08; Jinks, supra note 102, at 434-35.

184 The principal sources containing the legal arguments for the Administration's positions are two memoranda from high-level officials in the Department of Justice. See Memorandum from Jay S. Bybee, Assistant Att'y Gen., to Alberto Gonzales, Counsel to the President, \& William J. Haynes II, Gen. Counsel, Dep't of Def. (Jan. 22, 2002) [hereinafter Bybee Memo]; Memorandum from John Yoo \& Robert J. Delahunty, Office of Legal Counsel, Dep't of Justice, to William J. Haynes II, Gen. Counsel, Dep't of Def. (Jan. 9, 2002) [hereinafter Yoo-Delahunty Memo]. The analysis in these memoranda was later repeated in numerous public statements and litigation briefs. See Brief for Respondents at 37-43, 48-50, Hamdan v. Rumsfeld, 548 U.S. 557 (2006) (No. 05-184); Shumate, supra note 142 , at 4-10, 28-33 (citing Yoo-Delahunty Memo and other sources).

${ }^{185}$ See Bybee Memo, supra note 184, at 9-10; Yoo-Delahunty Memo, supra note 184, at 11-14. For criticisms of the Administration's interpretations of international law, see, e.g., Neil McDonald \& Scott Sullivan, Rational Interpretation in Irrational Times: The Third Geneva Convention and the "War on Terror," 44 HARV. INT'L L.J. 301, 306-07 (2003) (stating that the Administration's "selective application of [international law] is of questionable validity"). 
The Bush Administration's conclusion, however, relies on several highly contestable legal positions. ${ }^{186}$ If the armed conflict is international, the Administration ignores the applicability of the Fourth Convention to persons not protected by the Third, ${ }^{187}$ which would refute its claim that unlawful combatants are unprotected. ${ }^{188}$ More prominently, the Administration misinterprets Common Article 3 in three important ways. First, it claims that Common Article 3 does not apply in international armed conflicts. ${ }^{189}$ Second, it claims that Common Article 3 does not apply to all noninternational armed conflicts; rather, the Administration claims it only applies to those conflicts that occur within the territorial limits of a single state, involving hostilities with solely internal forces. ${ }^{190}$ Hence, the Administration claims that Common Article 3 does not apply to the conflict with al Qaeda because the conflict is outside the scope of both the international conflicts and the noninternational conflicts rules of the Conventions. ${ }^{191}$ As explained above,

${ }^{186}$ One of the Administration's positions is that members of al Qaeda do not qualify as POWs protected under the Third Convention. See Bybee Memo, supra note 184, at 910; Yoo-Delahunty Memo, supra note 184, at 13-14; Shumate, supra note 142, at 30-33, 56-59. If the Third Convention's POW protections were the exclusive applicable provisions, the Administration's claim might be correct. See supra notes 126-132 and accompanying text. As described above, however, other provisions of the Conventions also would be applicable. See supra notes 153-175 and accompanying text.

${ }^{187}$ The memoranda acknowledge the existence of the Fourth Convention but do not discuss its provisions or address its possible applicability. See Bybee Memo, supra note 184, at 1 n.1; Yoo-Delahunty Memo, supra note 184, at 1 n.1.

${ }^{188}$ See supra notes 148-163, 185 and accompanying text.

${ }^{189}$ See Bybee Memo, supra note 184, at 6-9, 31-32 ("Common article 3 . . . does not serve as a catch-all provision that applies to all armed conflicts, but rather as a specific complement to common article 2."); see also Yoo-Delahunty Memo, supra note 184, at 611 (stating that "common article 3 should not be read to include all forms of noninternational armed conflict").

${ }^{190}$ See Bybee Memo, supra note 184, at 6-9 ("Further, common article 3 addresses only non-international conflicts that occur within the territory of a single state party, again, like a civil war. This provision would not reach an armed conflict in which one of the parties operated from multiple bases in several different states."); see also Yoo-Delahunty Memo, supra note 184, at 6-11 (finding that there is "substantial reason" to think that common article 3 applies to a civil war or a "large-scale armed conflict between a state and an armed movement within its own territory").

${ }^{191}$ See Bybee Memo, supra note 184, at 10 (asserting that "the Geneva Conventions were intended to cover either: a) traditional wars between state parties to the Conventions (article 2), b) or non-international civil wars (article 3). Our conflict with al Qaeda does not fit into either category. It is not an international war between nation-States because al Qaeda is not a State. Nor is this conflict a civil war under article 3, because it is a conflict of 'an international character'"); see also Yoo-Delahunty Memo, supra note 184, at 12-13 (asserting that Al Qaeda conflict "is not an international war between Nation States" and "not a civil war under Article 3"); Shumate, supra note 142, at 66 (asserting historical precedent for individuals to fall outside the protection of the Conventions). 
each of these positions is contrary to consensus international law interpretations of the Conventions. ${ }^{192}$

As of August 2008, the federal courts have not addressed in detail the Administration's claims about the applicability of the international laws of war and the Geneva Conventions to members of al Qaeda. ${ }^{193}$ In its June 2006 Hamdan v. Rumsfeld decision, the United States Supreme Court rejected the Administration's approach and applied Common Article 3 to a captured al Qaeda member facing trial before a military commission convened by the President on his own authority. ${ }^{194}$ Importantly, however, the Court did not apply Common Article 3 of

${ }^{192}$ First, Common Article 3 does apply in international, as well as non-international conflicts. See supra notes 164-166 and accompanying text. Second, Common Article 3 does apply to all non-international armed conflicts, not just typical civil wars. See supra notes 100-105, 169-172 and accompanying text. Thus, there is no "gap" in the Conventions' coverage because every armed conflict is covered either by the Third and Fourth Conventions or by Common Article 3. See supra note 170; see also Ní Aoláin, supra note 106, at 1547-50; Jinks, supra note 97, at 188-89; Jinks, supra note 98, at 4041. "[T] he reading of the provision most faithful to its purpose and text is that Common Article 3 applies, as a formal matter, to all 'armed conflicts' not covered by Common Article 2." Jinks, supra note 98, at 41.

On the second point, the Bush Administration's position is particularly ironic, given the impetus for and purpose behind the adoption of Common Article 3.

[T]his understanding of the provision suggests that the most [sic] "civil wars" fall outside the rule. Most noninternational conflicts are transnational in the sense that the fighting spills over international borders. Indeed, even the Spanish Civil War - the historical case most often referenced in the Conventions drafting process as proof that international regulation of "internal" conflict was necessary-exhibited important transnational dimensions. [The same is true for] other paradigmatic applications of Common Article 3 including: Rwanda, Algeria, the Chechen Republic, Bosnia, Kosovo, and the Congo.

Jinks, supra note 97, at 189 n.45 (citations omitted). Thus, if the Bush Administration's position were correct, Common Article 3 would not apply to the very conflicts it was adopted to cover. But see Jinks, supra note 98, at 39-40 \& nn.260-267 (noting support for a narrow interpretation of Common Article 3's scope, and explaining why that interpretation "does not withstand close scrutiny").

${ }^{193}$ A few cases have addressed the applicability of the Conventions to Taliban fighters, however. See Hamdi v. Rumsfeld, 542 U.S. 507, 538-39 (2004); United States v. Lindh, 212 F. Supp. 2d 541, 552-55 (E.D. Va. 2002).

194 See 548 U.S. 557, 628-31 (2006), superseded by statute on other grounds, Military Commissions Act of 2006, Pub. L. No. 109-366, 120 Stat. 2600, as recognized in Boumediene v. Bush, 128 S.Ct. 2229, 2234 (2008). Before addressing the merits, the Court resolved two preliminary matters. First, it held that the Detainee Treatment Act of 2005 did not divest the Court of jurisdiction to hear Hamdan's claim. See id. at 572-84; cf. id. at 655-78 (Scalia, J., dissenting) (rejecting that analysis of the DTA). Second, it held that 
its own force, but rather held that its requirements applied because U.S. domestic law, particularly the Uniform Code of Military Justice, only authorized military commissions that comported with international law. ${ }^{195}$ The Court concluded that the military commission created to adjudicate the charges against Hamdan failed to comply with Common Article $3 .{ }^{196}$ Consequently, the Court did not have to decide whether the conflict with al Qaeda was international or noninternational, because Common Article 3 applied regardless. ${ }^{197}$ In June 2007, a panel opinion of the U.S.

abstention, by giving comity to ongoing military proceedings, was not appropriate. See id. at 583-92 (majority opinion).

195 The Court first held that the President had no Congressional authorization to convene military commissions outside the terms of the UCMJ. See id. at 590-95; id. at 636 (Breyer, J., concurring); cf. id. at 678-83 (Thomas, J., dissenting) (arguing that the President did not need congressional authorization). A plurality of the Court also questioned the validity of the conspiracy charge under the laws of war. See id. at 595-613 (Stevens, J., plurality opinion); see also id. at 653-55 (Kennedy, J., concurring) (declining to decide that question); $c f$. id. at 683-706 (Thomas, J., dissenting) (rejecting plurality's analysis); $i d$. at 725-27 (Alito, J., dissenting) (same). Next, the Court held that the military commission convened by the President to try Hamdan was not consistent with the UCMJ's provisions authorizing deviations from regular court-martial procedures in certain circumstances. See id. at 613-25 (majority opinion); id. at 636-53 (Kennedy, J., concurring); $c f . i d$. at 706-15 (Thomas, J., dissenting) (rejecting majority's analysis of the UCMJ). Then the Court turned to the Common Article 3 issues. Id. at 629-33 (majority opinion).

${ }^{196}$ First, the Court held that Hamdan had individual standing to raise non-compliance with Common Article 3 because, even if the Geneva Conventions did not provide a remedy to aggrieved individuals, Hamdan could assert the violation of the UCMJ itself. See id. at 625-28; cf. id. at 715-19 (Thomas, J., dissenting) (rejecting individual standing). Second, the Court held that Common Article 3 applied to the conflict with al Qaeda in Afghanistan, where Hamdan was captured. See id. at 628-31 (majority opinion); cf. id. at 718-19 (Thomas, J., dissenting) (arguing that the Court should defer to the President's contrary interpretation). Third, the Court held that the military commission convened by the President to try Hamdan failed to satisfy Common Article 3's "regularly constituted court" requirement. See id. at 627-33 (majority opinion); id. at 636-53 (Kennedy, J., concurring); cf. $i d$. at 719-21 (Thomas, J., dissenting) (rejecting majority's analysis); id. at 725-34 (Alito, J., dissenting). A plurality of the court also opined that several aspects of the commissions failed to meet the "indispensable" judicial guarantees requirement. See id. at 633-35 (Stevens, J., plurality opinion); id. at 653-55 (Kennedy, J., concurring); $c f . i d$. at 721-24 (Thomas, J., dissenting) (rejecting plurality's analysis). Thus, the Court held that the commissions violated Common Article 3. See id. at 635 (Stevens, J., plurality opinion) ("The commission that the President has convened to try Hamdan does not meet those requirements.").

${ }^{197}$ The Court stated:

Since Hamdan was captured and detained incident to the conflict with al Qaeda and not the conflict with the Taliban, and since al Qaeda, unlike Afghanistan, is not a "High Contracting Party"-i.e., a signatory of the Conventions, the 
Court of Appeals for the Fourth Circuit held that the conflict with al Qaeda was noninternational, and therefore subject to Common Article 3, but that position did not garner a majority upon rehearing en banc in July $2008 .^{198}$

In direct response to the Supreme Court's June decision in Hamdan, in September the U.S. Congress passed the Military Commissions Act of 2006 (MCA). ${ }^{199}$ The MCA specifically authorizes the President to convene military

protections of those [four Geneva] Conventions are not, it is argued, applicable to Hamdan.

We need not decide the merits of this argument because there is at least one provision of the Geneva Conventions that applies here even if the relevant conflict is not one between signatories.

Id. at 629 (majority opinion). But see Ní Aoláin, supra note 106, at 1535 ("The Court's decision not to address Hamdan's status in the context of the law of war relevant to the conflict in Afghanistan is politically understandable but legally regrettable."); see also Jack M. Beard, The Geneva Boomerang: The Military Commissions Act of 2006 and U.S. Counterterror Operations, 101 AM. J. INT'L. L. 56, 63 (2007) ("The Geneva Conventions fail to explain precisely what constitutes a 'conflict not of an international character' and no definition of that term enjoys universal acceptance other than statements contrasting it with its opposite. As a result, it was not a foregone conclusion that the U.S. Supreme Court in Hamdan would ultimately decide that Qaeda terrorists are engaged in an armed conflict governed by common Article 3." (quoting MOIR, supra note 98, at 32)).

${ }^{198}$ In al-Marri, the Fourth Circuit panel majority relied on Hamdan to find that "the conflict with al Qaeda in Afghanistan is a non-international conflict." See al-Marri v. Wright, 487 F.3d 160, 185 (4th Cir. 2007). Accordingly, the panel held that the "enemy combatant" doctrines applicable in international armed conflicts were inapplicable to alMarri and could not justify his military detention. See id. at 184-86. The panel also noted that the Supreme Court's analysis in Hamdan only recognized the existence of an armed conflict with al Qaeda in Afghanistan, where Hamdan was captured - not within the United States, where al-Marri was seized. See id. at 185 n.14.

Interestingly, the panel opinion several times erroneously described the Supreme Court's analysis in Hamdan as a "holding" on the issue. See id. at 184-85. The Supreme Court in Hamdan did not need to decide whether the conflict with al Qaeda was international or non-international because, notwithstanding the seemingly contrary implication of its text, Common Article 3 applies to both kinds of conflicts. See supra note 197 and accompanying text.

On rehearing en banc, the author of the panel opinion reprised these arguments. See al-Marri v. Wright, 534 F.3d 213, 233-35 (4th Cir. 2008) (en banc) (Motz, J., concurring). This analysis was not joined by a majority of the judges, however. See id. at 216 (per curiam opinion of the court). The Supreme Court subsequently granted certiorari to review the en banc decision. See 129 S. Ct. 680 (Dec. 5, 2008).

199 See Military Commissions Act of 2006, Pub. L. No. 109-366, 120 Stat. 2600 (codified at 10 U.S.C. $\$ \S 948 \mathrm{a}-50 \mathrm{w}$ and other sections of titles 18,28 , and 42). The final bill passed the Senate on September 28, 2006, and the House on September 29. See 152 CONG. REC. S10,420 (daily ed. Sept. 28, 2006); 152 CONG. REC. H7914 (daily ed. Sept. 29, 2006). The bill was presented to the President on October 10, 2006; he signed it on October 17. Library of Congress, THOMAS Bills, Resolutions, http://thomas.loc.gov/cgi- 
commissions for trials of accused terrorists and war criminals. ${ }^{200}$ Persons subject to trial by military commission must be noncitizens and must be unlawful enemy combatants. ${ }^{201}$ The MCA authorizes jurisdiction for the military commissions and includes numerous procedural provisions for the commissions and their proceedings. ${ }^{202}$ The MCA also lists and defines the offenses triable by the military commissions. $^{203}$

The MCA defines an unlawful enemy combatant as "a person who has engaged in hostilities . . . against the United States or its co-belligerents who is not a lawful enemy combatant." 204 The statute specifically defines members of al Qaeda as unlawful enemy combatants. ${ }^{205}$ For its definition of lawful enemy combatant, the MCA draws directly from the Third Convention's provisions on prisoners of war. ${ }^{206}$ The exclusion of lawful combatants from the MCA accords

bin/bdquery/z?d109:SN03930:@@@ (last visited Dec. 1, 2008). For a summary of the impetus behind the MCA and the legislative history of its drafting, see Carlos Manuel Vazquez, The Military Commissions Act, the Geneva Conventions, and the Courts: A Critical Guide, 101 AM. J. INT'L. L. 73, 73-76 (2007).

${ }^{200}$ See 10 U.S.C. $\S 948$ b(a)-(b) (2006). In rejoinder to the Supreme Court in Hamdan, the statute declares that "[a] military commission established under this chapter is a regularly constituted court, affording all the necessary 'judicial guarantees which are recognized as indispensable by civilized peoples' for purposes of common Article 3 of the Geneva Conventions." Id. $\S 948 \mathrm{~b}(\mathrm{f})$ (quoting common Article 3). The MCA further repudiates the Court's analysis of prior law by declaring that the Geneva Conventions are not a source of rights that may be invoked by an individual war crimes defendant, whether before the military commission itself or in a habeas corpus proceeding. See $i d . \$ 948 \mathrm{~b}(\mathrm{~g})$ ("No alien unlawful enemy combatant subject to trial by military commission under this chapter may invoke the Geneva Conventions as a source of rights."); Military Commissions Act of 2006, Pub. L. No. 109-366, § 5(a), 120 Stat. 2600, 2631 ("No person may invoke the Geneva Conventions or any protocols thereto in any habeas corpus ... proceeding to which the United States . . . is a party as a source of rights in any court of the United States ...."); see also Vazquez, supra note 199, at 82-97 (criticizing and questioning the validity, under international and U.S. law, of these provisions).

${ }^{201}$ See 10 U.S.C. $\S 948$ c ("Any alien unlawful enemy combatant is subject to trial by military commission under this chapter."); id. $\S 948 \mathrm{a}(3)$ ("The term 'alien' means a person who is not a citizen of the United States.").

${ }^{202}$ See id. $\S 948 \mathrm{~d}$ (jurisdiction); id. $\S \S 948 \mathrm{~h}-948 \mathrm{~m}$ (composition of military commission); id. $\S \S 948 \mathrm{q}-948 \mathrm{~s}$ (pretrial procedures); id. $\S \S 949 \mathrm{a}-949 \mathrm{o}$ (trial procedures); id. $\S \S 949 \mathrm{~s}-949 \mathrm{u}$ (sentencing provisions); id. $\S \S 950 \mathrm{a}-950 \mathrm{j}$ (post-trial procedures, appeals and review of judgments).

${ }^{203}$ See id. $\S \S 950 \mathrm{p}-950 \mathrm{w}$ (offenses and culpability doctrines).

${ }^{204}$ Id. $\S 948 \mathrm{a}(1)(\mathrm{A})(\mathrm{i})$.

${ }^{205}$ See id. ("(including a person who is part of the Taliban, al Qaeda, or associated forces)") (parenthetical clause in original).

${ }^{206}$ A lawful enemy combatant is defined as:

(A) a member of the regular forces of a State party engaged in hostilities against the United States; 
with the Third Convention; although such persons could be prosecuted by the United States for war crimes, those trials must occur in the same courts-martial applicable to U.S. soldiers, not in separate, specially constituted military commissions. ${ }^{207}$ But other combatants, including unlawful combatants in an international armed conflict or any combatants in a noninternational armed conflict, are susceptible to coverage by the MCA. Because they lack combatant immunity, they can be charged with crimes under the laws of war or domestic law. ${ }^{208}$ Because they are not protected lawful combatants, they need not be tried by courts-martial. ${ }^{209}$ Therefore, the MCA's definitional provisions are to this extent consistent with the existing international laws of war. ${ }^{210}$

Another aspect of the MCA's definition of unlawful enemy combatants is highly controversial, however. ${ }^{211}$ The MCA reaches not only individuals who personally participated in hostilities, but also any person "who has purposefully and materially supported hostilities." ${ }^{212}$ By contrast, under international law, only persons who are "directly" or "actively" engaged in hostilities are deemed to be combatants. ${ }^{213}$ Other persons, including those who supported combatants engaged

(B) a member of a militia, volunteer corps, or organized resistance movement belonging to a State party engaged in such hostilities, which are under responsible command, wear a fixed distinctive sign recognizable at a distance, carry their arms openly, and abide by the law of war; or

(C) a member of a regular armed force who professes allegiance to a government engaged in such hostilities, but not recognized by the United States.

Id. $\S 948 \mathrm{a}(2)$. The MCA repeats the structure of the Third Convention's definitions, which list the four criteria only for irregulars. See supra note 131.

${ }^{207}$ See supra notes $136-137$ and accompanying text.

${ }^{208}$ See supra notes 160,181 and accompanying text.

${ }^{209}$ See supra notes $155-157,182-183$ and accompanying text.

${ }^{210}$ Whether the procedures provided in the MCA satisfy the existing international laws of war is also highly controversial. See supra note 202 (citing MCA procedural provisions); supra note 157 (citing procedural provisions of GCCP); supra notes 182-183 (citing and discussing procedural requirements of Common Article 3); see, e.g., David Glazier, Full and Fair by What Measure?: Identifying the International Law Regulating Military Commission Procedure, 24 B.U. INT'L L.J. 55, 70-94, 97-103 (2006) (noting disparities between the procedural provisions of the MCA and international law); James G. Stewart, The Military Commission Act's Inconsistency with the Geneva Conventions: An Overview, 5 J. INT'L CRIM. JUST. 26, 29-32, 35-37 (2007) (discussing the divergence between the MCA's procedures and the procedures of the Geneva Conventions).

${ }^{211}$ See Beard, supra note 197, at 59-60, 66-67 (2007) (discussing the MCA's controversial expansion of combatant status and its divergence from international law).

${ }^{212} 10$ U.S.C. $\S 948 \mathrm{a}(1)(\mathrm{A})(\mathrm{i})(2006)$.

${ }^{213}$ See supra note 117 (citing sources); see also Jinks, supra note 106, at 1497 ("Noncombatants are granted immunity from attack so long as they do not participate directly in the hostilities.") (emphasis added); GCPW, supra note 101, art. 3 (stating that "[p]ersons taking no active part in the hostilities" shall not be subjected to inhumane treatment such as "violence to life and person") (emphasis added). 
in hostilities, are noncombatants. ${ }^{214}$ The MCA's expansion of combatant status is therefore plainly inconsistent with existing international law. ${ }^{215}$

The MCA also defines the full list of war crimes triable by the military commissions authorized by the statute. ${ }^{216}$ Most of the offenses are traditional violations of the laws of war, including attacking civilians, denying quarter, improperly using a flag of truce, and committing rape. ${ }^{217}$ In terms generally consistent with international law, the MCA provides for liability under the doctrine of command responsibility, holding superior officers accountable for war crimes committed at their direction or by their subordinates, ${ }^{218}$ and imposes vicarious liability for aiding and abetting. ${ }^{219}$ But the MCA also includes three controversial offenses that depart in significant ways from existing international law.

First, the MCA includes "terrorism" as a separate triable offense. ${ }^{220}$ It defines terrorism as intentionally killing or endangering civilians for purposes of intimidation, coercion, or retaliation. ${ }^{221}$ This definition of terrorism is taken

${ }^{214}$ See supra notes 114-123 and accompanying text; see, e.g., Protocol I, supra note 102, art. 51(3) ("Civilians shall enjoy the protection afforded by this Section, unless and for such time as they take a direct part in hostilities.") (emphasis added).

${ }^{215}$ See Beard, supra note 197, at 59-60, 66-67 (2007) (arguing that the distinction between noncombatants and combatants "remains a bedrock principle of the law of war" and that the MCA's expansion of combatant status "melts this distinction").

${ }^{216}$ See 10 U.S.C. $\$ 950 \mathrm{v}$.

${ }^{217}$ See id. $\S 950 \mathrm{v}(\mathrm{b})(3),(6),(18) \&(21)$; see, e.g., DINSTEIN, supra note 107, at 22833 (listing and discussing war crimes); GREEN, supra note 107, at 295-303 (discussing war crimes recognized by international law).

${ }^{218}$ See 10 U.S.C. $\$ 950 \mathrm{q}$ ("Any person is punishable as a principal under this chapter who-(1) commits an offense punishable by this chapter, or...commands... its commission; (2) causes an act to be done which if directly performed by him would be punishable ...; or (3) is a superior commander who... knew, had reason to know, or should have known, that a subordinate was about to commit such acts or had done so and who failed to take the necessary and reasonable measures to prevent such acts or to punish the perpetrators thereof.") (emphasis added). To the extent that the MCA definition is premised not on actual or constructive knowledge, but is based in ordinary negligence ("should have known"), it is inconsistent with international law. See DINSTEIN, supra note 107 , at $237-42$.

21910 U.S.C. $\S 950 \mathrm{q}(1)$ ("Any person is punishable as a principal under this chapter who... commits an offense punishable by this chapter, or aids, abets, counsels, commands, or procures its commission."). The language on aiding and abetting is nearly verbatim from $\S 2$, although the MCA omits one actus reus verb ("induces"). Compare 10 U.S.C. $\S 950 \mathrm{q}(1)$, with 18 U.S.C. $§ 2$ (a) ("Whoever commits an offense against the United States or aids, abets, counsels, commands, induces or procures its commission, is punishable as a principal.").

${ }^{220}$ See id. $\$ 950 \mathrm{v}(\mathrm{b})(24)$.

${ }^{221}$ Id. Under the MCA, the offense of terrorism occurs when a person:

... intentionally kills or inflicts great bodily harm on one or more protected persons, or intentionally engages in an act that evinces a wanton disregard for 
straight from U.S. criminal law. ${ }^{222}$ Of course, prosecuting acts of terrorism committed during armed conflict is uncontroversial to the extent those acts would constitute war crimes even without any terrorist motive or connection. ${ }^{223}$ For example, intentionally attacking civilian targets is a war crime; so is intentionally murdering prisoners of war protected by the Third Convention or protected persons under the Fourth Convention. ${ }^{224}$ There is considerably less support under the existing international laws of war for treating terrorism as a freestanding, separate war crime - particularly considering the breadth of the MCA's definition. ${ }^{225}$

Second, the MCA also includes the offense of "providing material support for terrorism" as a triable war crime. ${ }^{226}$ Just like the $\S 2339 \mathrm{~B}$ federal crime, ${ }^{227}$ this MCA crime proscribes intentionally providing support or resources toward the commission of an act of terrorism or to a terrorist organization generally. ${ }^{228}$ In fact,

human life, in a manner calculated to influence or affect the conduct of government or civilian population by intimidation or coercion, or to retaliate against government conduct.

Id. A protected person is "any person entitled to protection under one or more of the Geneva Conventions, including ... civilians not taking an active part in hostilities." Id. § $950 \mathrm{v}(\mathrm{a})(2)$.

${ }^{222}$ Compare id. §950v(b)(24) (defining terrorism to include acts committed "in a manner calculated to influence or affect the conduct of government or civilian population by intimidation or coercion, or to retaliate against government conduct"), with 18 U.S.C. § 2332(d) (2006) (authorizing prosecution under this section upon certification that "such offense was intended to coerce, intimidate, or retaliate against a government or a civilian population").

${ }^{223}$ See Jinks, supra note 102, at 437 \& nn.384-387; Jinks, supra note 106, at 1520-21 \& nn. $112-115$.

${ }^{224}$ See Jinks, supra note 102 , at 437 \& n.384; Jinks, supra note 106 , at $1520-21$ \& n.112; see also supra notes $110-113$ and accompanying text (discussing attacks on civilians); GCCP, supra note 101, art. 147 (defining, inter alia, murdering protected persons as a grave breach of the Fourth Convention), GCPW, supra note 101, art. 130 (same under the Third Convention).

${ }^{225}$ See Jinks, supra note 102 , at $437 \&$ n.384; Jinks, supra note 106 , at $1520-21 \&$ n.112. Protocol I to the Geneva Conventions states that "[a]cts or threats of violence the primary purpose of which is to spread terror among the civilian population are prohibited." Protocol I, supra note 102, art. 51(2). The authorizing document of the International Criminal Tribunal for Rwanda included "the power to prosecute persons committing or ordering to be committed serious violations of Article 3 common to the Geneva Conventions ... and of Additional Protocol II thereto... [which] shall include, but shall not be limited to ... acts of terrorism," but it provided no further definition of that term. See Statute of the International Criminal Tribunal for Rwanda, S.C. Res. 955, Annex, art. 4(d), U.N. SCOR, 49th Sess., 3453d mtg., U.N. Doc. S/RES/955/Annex (Nov. 8, 1994).

${ }^{226}$ See 10 U.S.C. § 950v(b)(25)(A).

${ }^{227}$ See supra notes $48-51$ and accompanying text.

${ }^{228}$ See 10 U.S.C. § 950v(b)(25)(A) ("Any person subject to this chapter who provides material support or resources, knowing or intending that they are to be used in preparation 
the MCA does not even include its own definition of "material support" but rather incorporates by reference the definition in the U.S. Criminal Code. ${ }^{229}$ Thus, this crime is nothing more than a direct transposition of a regular federal offense into a "war crime" under the MCA. But material support for terrorism is a recent development, even in U.S. domestic criminal law. ${ }^{230}$ There is no support in the existing international laws of war for a war crime on this theory of liability. ${ }^{231}$

Third, the MCA provides for inchoate liability for the war crimes included in its terms. Under the MCA, a conspiracy to commit any of the other triable offenses is itself a war crime. ${ }^{232}$ This definition of conspiracy is taken directly from U.S.

for, or in carrying out, an act of terrorism ... or who intentionally provides material support or resources to an international terrorist organization engaged in hostilities against the United States, knowing that such organization has engaged or engages in terrorism shall be punished as a military commission under this chapter may direct."). The offense incorporates by reference the definition of "terrorism" in $\S 950 \mathrm{v}(\mathrm{b})(24)$. See id. $\S$ $950 \mathrm{v}(\mathrm{b})(25)(\mathrm{A})$. The material support offense is not capital even if the act of terrorism supported results in death, see $i d$., unlike the crime of terrorism itself, see $i d$. $\S 950 \mathrm{v}(\mathrm{b})(24)$ ("Any person subject to this chapter shall be punished, if death results to one or more of the victims, by death or such other punishment as a military commission under this chapter may direct, and, if death does not result to any of the victims, by such punishment, other than death, as a military commission under this chapter may direct ....").

${ }^{229}$ See id. § 950v(b)(25)(B) ("In this paragraph, the term "material support or resources' has the meaning given that term in section 2339A(b) of title 18.").

${ }^{230}$ See Chesney, supra note 47 , at 88-89.

${ }^{231}$ See Beard, supra note 197, at 61-67 (describing material support theory as "unprecedented" in international laws of war); see also George P. Fletcher, On the Crimes Subject to Prosecution in Military Commissions, 5 J. INT'L CRIM. JUST. 39, 45-46 (2007) (noting that the MCA lays the "foundation for the following radical extension of military commission jurisdiction").

${ }^{232}$ See 10 U.S.C. $\S 950 \mathrm{v}(\mathrm{b})(28)$ ("Any person subject to this chapter who conspires to commit one or more substantive offenses triable by military commission under this chapter, and who knowingly does any overt act to effect the object of the conspiracy ... shall be punished ... as a military commission under this chapter shall direct."). The MCA made a conforming amendment to the Uniform Code of Military Justice, adding conspiracy to commit a war crime under the laws of war as an offense triable by court-martial or military commission; this supplemented the preexisting offense of conspiracy to commit a crime in violation of the UCMJ itself, which is triable by court-martial. See id. § 881(b); see also Military Commissions Act of 2006, Pub. L. No. 109-366, $\$ 4(b), 120$ Stat. 2600, 2631 (adding text of new subsection (b) to $\S 881$ and labeling the previous text of $\S 881$ as new subsection (a)). Like many other provisions of the MCA, this offense is a response to a section of the plurality opinion in the Supreme Court's Hamdan decision. See Hamdan v. Rumsfeld, 548 U.S. 557, 595-613 (2006) (Stevens, J., plurality opinion) (arguing that conspiracy to commit a war crime is not a cognizable offense under the laws of war); $i d$. at 653-54 (Kennedy, J., concurring) (declining to join the plurality's analysis). But see id. at 681-706 (Thomas, J., dissenting) (rejecting the plurality's analysis and arguing that conspiracy to a commit a war crime is a valid charge under the laws of war). 
federal criminal law. ${ }^{233}$ By contrast, the existing international laws of war do not recognize inchoate liability. ${ }^{234}$

The controversial provisions of the MCA are problematic because they appear to be an attempt by the United States to expand international law unilaterally. ${ }^{235}$ But even if the MCA does simply contradict existing war crimes doctrines under international law - such as by assigning combatant status to someone who merely supports hostilities, or by imposing inchoate liability for conspiracy to commit a war crime-public discourse and the political process may be the only recourse. When Congress and the President combine to unambiguously supersede or contravene a prior treaty by a subsequent statute, the federal courts will apply the statute. ${ }^{236}$ Thus, it is entirely possible the courts might resolve inconsistency

${ }^{233}$ In fact, the language is verbatim. Compare 10 U.S.C. $\S 950 \mathrm{v}(\mathrm{b})(28)$ ("Any person . . . who conspires to commit one or more substantive offenses triable by military commission ... shall be punished ...."), with 18 U.S.C. $\S 371$ (2006) ("If two or more persons conspire ... to commit any offense against the United States ... each shall be fined[,] . . . imprisoned[,] . . or both."). The overt act requirement, however, differs: $\S$ $950 \mathrm{v}(\mathrm{b})(28)$ of the MCA requires that a conspiracy defendant "knowingly does" at least one overt act personally, while $\S 371$ (and traditional conspiracy law) only requires that any one of the conspirators do so. See 18 U.S.C. $\S 371$ (stating that each conspirator shall be found guilty if "one or more of such persons do any act to effect the object of the conspiracy").

${ }^{234}$ See supra notes 122-123 and accompanying text; see also Beard, supra note 197, at 60-61 (discussing MCA's use of inchoate liability in contradiction to the laws of war); Fletcher, supra note 231, at 46 ("The MCA 2006 eliminates the use of conspiracy as a surrogate for proving actual complicity by aiding and abetting. But it does include a separate stand-alone offence of conspiracy as an inchoate crime. This was precisely the form of conspiracy invalidated by the Stevens's plurality in Hamdan.").

${ }^{235}$ One commentator noted that:

At a fundamental level, unilateral revision of the Geneva Conventions by the United States undermines the credibility of the U.S. commitment to the existing Geneva regime. To the extent ... the MCA is perceived as unilaterally revising key obligations in the Geneva Conventions and providing the president with the discretion to issue further reinterpretations, it undermines the credible commitment of the United States to other states in the international community.

Beard, supra note 197, at 65; see also id. at 64-69 (discussing the controversial provisions of the MCA); Michael C. Dorf, The Orwellian Military Commissions Act of 2006, $5 \mathrm{~J}$. INT'L CRIM. JUST. 10, 17-18 (2007) ("Accordingly, despite its repeated invocations of the Geneva Conventions, the MCA in fact authorizes the United States to breach those Conventions, because it authorizes the opening of a gap between the US-sourced only interpretation of the Conventions and the consensus view of the international community.").

${ }^{236}$ See, e.g., RESTATEMENT (THIRD) OF THE FOREIGN RELATIONS LAW OF THE UNITED STATES $\S 115(1)(a)$ (1987) ("An act of Congress supersedes an earlier rule of international law or a provision of an international agreement as law of the United States if the purpose 
between the MCA and the Geneva Conventions in favor of the MCA. ${ }^{237}$ Nonetheless, the controversy highlights the developing nature of international law and the increasing tensions posed by the threat of al Qaeda and other transnational terrorist groups.

\section{B. The Complexities}

Even on their own terms, in situations where their provisions undoubtedly apply, the international laws of war embodied in the Geneva Conventions often can be complex and difficult to implement in the realities of conflict on the ground. The interpretive dilemmas become even more intractable when these provisions are transposed to the situation of transnational terrorist organizations like al Qaeda.

It is indisputable that the threat of transnational terrorist organizations, as such, is not directly contemplated within the terms of the existing Conventions framework. ${ }^{238}$ Analogies can be drawn to situations and issues which are addressed by the Conventions, and inferences can be made about the best way to extend

of the act to supersede the earlier rule or provision is clear or if the act and the earlier rule or provision cannot be fairly reconciled."). On the other hand, where the intent to supersede or abrogate is ambiguous, the so-called Charming Betsy canon instructs courts to construe the statute to avoid violating the treaty (or other international law). See Murray v. The Schooner Charming Betsy, 6 U.S. (2 Cranch) 64, 99-100 (1804); Vazquez, supra note 199, at 80-81; see also Ingrid Brunk Wuerth, Authorizations for the Use of Force, International Law, and the Charming Betsy Canon, 46 B.C. L. REv. 293, 330-56 (2005) (discussing the Charming Betsy canon and analyzing its application to the AUMF at issue in Hamdiv. Rumsfeld, 542 U.S. 507 (2004)).

${ }^{237}$ But see Vazquez, supra note 199, at 80-82 (arguing that, because Congress expressed an intention to implement, not violate, Common Article 3 and the Geneva Conventions, "the Charming Betsy canon should kick in and lead the courts to opt for the solution that preserves U.S. treaty commitments"). George Fletcher argues that in the MCA:

Congress purports to be acting under its legislative authority granted under Article I, Section 8, Clause 10 of the [Constitution], "to define offenses against the law of nations." In so far as some of these offences are not violations of the law of nations, they fall outside the field of legislative competence.

Fletcher, supra note 231, at 47; see also Fletcher, supra note 123, at 438-39 (arguing that the clause gives Congress the power to make international law offenses cognizable in U.S. courts, but not the power to determine which offenses exist in the law of nations).

${ }^{238}$ See, e.g., Geoffrey S. Corn, Hamdan, Lebanon, and the Regulation of Hostilities: The Need to Recognize a Hybrid Category of Armed Conflict, 40 VAND. J. TRANSNAT'L L. 295, 300-10 (2007) (discussing problems with applying the Geneva Conventions to transnational terrorist organizations); Murphy, supra note 145, at 1132-34 (same); Sloane, supra note 96 , at $443,452-54$ (arguing that transnational terrorist organizations cannot be integrated into the Geneva Conventions framework). 
existing principles to this unaddressed situation. Nevertheless, the foundational conceptual problem remains: the Conventions simply were not designed with this contemporary threat in mind.

The divergences between the existing Conventions framework and the situation of al Qaeda and other transnational terrorist organizations are numerous and not insignificant. Most obviously, al Qaeda is not the formal government or regular armed forces of any state, nor is it a party to the Conventions. Yet al Qaeda engages in armed conflict much like a state: it carries out acts of violence against states that would constitute acts of war if committed by agents of a state, ${ }^{239}$ and its leaders purport to have declared war with the United States and other Western powers. ${ }^{240}$ Likewise, al Qaeda does not fit within the other existing categories of armed groups recognized in the Conventions, such as irregulars, militias, insurgents, or freedom fighters participating alongside or against state forces in international armed conflicts. ${ }^{241}$ Just like such groups, al Qaeda is an organized armed force capable of projecting violence against states-but it is diffuse and not strictly hierarchical like a traditional military or paramilitary force. ${ }^{242}$ In further contrast to the traditional nonstate organized armed groups recognized in the Conventions framework, al Qaeda rejects the fundamental tenets of the Conventions-especially the privileged status of noncombatants-and would not join them even if given the legal or practical opportunity. ${ }^{243}$ Finally, the Conventions framework also specifically contemplates hostilities between states and nonstate groups during noninternational armed conflicts. ${ }^{244}$ The paradigm of a

${ }^{239}$ See Ní Aoláin, supra note 106, at 1560-61; Jinks, supra note 97, at 166, 183, 184 n.38, 193 n.52; Watkin, supra note 106, at 18.

${ }^{240}$ See Hamdan v. Rumsfeld, 548 U.S. 557, 687-88 (2006) (Thomas, J., dissenting) (citing statements from Osama bin Laden and others).

${ }^{241}$ See supra notes 131-132 and accompanying text. In international armed conflicts, irregulars, militias, and organized resistance movements "belonging to a Party to the conflict and operating in or outside their own territory" may qualify as lawful combatants. GCPW, supra note 101, art. 4(A)(2). Because al Qaeda is neither a state Party nor attached to any state Party engaged in international armed conflict, it cannot, by definition, meet these criteria. See Berman, supra note 97, at 40-41, 44-45; Jinks, supra note 97, at 181-82 (noting the possibility that al Qaeda's relationship with the Taliban regime might meet this requirement during hostilities in Afghanistan). In addition, al Qaeda also clearly falls outside the scope of the controversial provisions of Protocol I that extend lawful combatant status to freedom fighters in wars of national liberation. See Sloane, supra note 96, at 45051 (discussing Protocol I, supra note 102, arts. 1, 43-44).

${ }^{242}$ See Sloane, supra note 96 , at 450.

${ }^{243}$ See id. at 452 . Because of the national liberation movement ("NLM") paradigm, "[t]he Protocol I debate presumed that if only the laws of war could be revised to make compliance by non-state actors practicable, NLMs would wish to comply; NLMs did not characteristically or in principle reject the principle of distinction, noncombatant immunity, or any other precept of [international humanitarian law]." Id. at 468.

${ }^{244}$ See supra notes $169-173$ and accompanying text. 
single state embroiled in intense, sustained internal armed conflict, however, is far removed from the nature of the violence carried out by al Qaeda, which is global in scope and directed episodically against numerous different states. ${ }^{245}$ Many of al Qaeda's principal targets, like the United States and Western European nations, are not otherwise affected by anything resembling a noninternational armed conflict. Thus, the existing Conventions framework does not directly take account of the distinct nature of the threat posed by transnational terrorist organizations.

One fundamental component of the existing laws of war is the concept of the "combatant," yet precision in defining it is surprisingly lacking. Understanding who is a combatant is crucial, not only for purposes of detaining or punishing enemy soldiers, but also for selecting legitimate military targets-and most importantly for identifying the noncombatants and civilians to whom privileged protected status is owed. ${ }^{246}$ Despite these critical roles, the Conventions leave the definition of combatant ambiguous, especially with regard to participants in hostilities other than the regular armed forces of states. ${ }^{247}$ The definitions of legitimate military objectives are equally imprecise, to the point that "commanders may not be operating under rules as much as standards."248 This imprecision renders decision making difficult for soldiers on the battlefield, who must make

The challenge presented by contemporary trans-national terrorists . . . is their ability to project state-like violence beyond the borders of a single state. As a result, a conflict between states and private actors, which is traditionally viewed as an internal affair, is now being played out on an international scale.

Watkin, supra note 106, at 18.

${ }^{245}$ See Corn, supra note 238, at 311-15 (emphasizing that terrorism is neither a traditional international armed conflict under Common Article 2 because it is not between states nor a traditional non-international armed conflict under Common Article 3 because it is not a civil war); Sloane, supra note 96 , at 453 (emphasizing the episodic nature of al Qaeda violence).

${ }^{246}$ Sloane, supra note 96 , at $470-73$.

${ }^{247}$ See, e.g., Jensen, supra note 97, at 218-24 (emphasizing the ambiguous nature of GCPW Article 4); Jinks, supra note 102, at 374 (discussing the competing interpretations of qualification for combatant status); Jinks, supra note 106, at 1521 (discussing the limited protection of combatant immunity when combatant status is ambiguously defined); David Kaye, Complexity in the Law of War, in 60 DEVELOPMENTS IN INTERNATIONAL LAW: Progress In InTERNational LAW 700-02 (Russell A. Miller \& Rebecca M. Bratspies eds., 2008) (arguing that Protocol I's provisions further complicates combatant status determinations); see also Berman, supra note 97, at 41-50 (discussing reasons for the persistence of the ambiguous definition of combatant status under the Conventions).

${ }^{248}$ Kaye, supra note 247, at 696; see also DINSTEIN, supra note 107, at 94-99, 108 112 (noting problems of indeterminacy in the definition of military objectives); Kaye, supra note 247, at 693-700 (discussing the "abstract and generic" definitions of legitimate military objectives and the law of targeting). 
quick judgments about whether or not to attack a potential threat. ${ }^{249}$ The interpretive problem is particularly acute when dealing with guerrillas, insurgents, and other fighters who blend into civilian populations and only intermittently engage in hostilities. ${ }^{250}$ Although such persons would be unlawful combatants while engaged in hostilities, they may attempt to argue that they should be considered noncombatants while not actively fighting — a claim so far rejected by the Conventions framework. ${ }^{251}$

Transposing the concept of combatant status to transnational terrorist organizations exacerbates the definitional difficulties. What degree of participation in al Qaeda should be necessary before a noncombatant is deemed to have become a combatant? In the traditional laws of war paradigm, a civilian becomes a combatant in an international conflict by enlisting in the regular or irregular armed forces of a state or by joining an organized resistance movement or a spontaneous uprising against invaders; in a paradigmatic noninternational armed conflict, a civilian becomes a combatant by personally taking up arms in an armed insurrection against his own state. ${ }^{252}$ Should simply joining al Qaeda, like

${ }^{249}$ See Kaye, supra note 247, at 701 ("[T]ime to consider whether a person has earned [combatant status] . . . may not be available in a situation of a military engagement, where a commander will need to determine whether a particular individual has combatant status and thus is liable to be attacked.").

${ }^{250}$ See id. at 698-99 ("For instance, imagine that a guerilla force has dispersed itself and its weapons throughout a residential neighborhood in order to shield itself with civilians and civilian objects .... May the military force attack the neighborhood, thereby targeting civilians and military objects necessarily without distinction? Or must the force let the guerilla force be ... ? These are not easy questions, and even if there are answers, it is unlikely that opposing forces will agree on their outcome."); see also Protocol I, supra note 102, arts. 43(1), 44(3) (defining combatant status for certain irregular forces engaged in wars of national liberation).

${ }^{251}$ See DINSTEIN, supra note 107, at 28-29 ("[A] person cannot (and is not allowed to) be both a combatant and a civilian at the same time, nor can he constantly shift from one status to the other. ... [A] person is not allowed to wear simultaneously two caps: the hat of a civilian and the helmet of a soldier. A person who engages in military raids by night, while purporting to be an innocent civilian by day, is neither a civilian nor a lawful combatant. He is an unlawful combatant."); see also Berman, supra note 97, at 51-55 (discussing the problem of part-time combatants under Protocol I).

${ }^{252}$ See DinSTEIN, supra note 107 , at $27-33$. Thus, while the laws of war apply broad status categories - noncombatant, lawful combatant, and unlawful combatant - to allocate the scope of applicable privileges and protections, an individual's own personal conduct ultimately determines which classification he or she receives. For example, certain groups in international armed conflicts (like regular armed forces) comply with the requirements of the GCPW and thereby entitle their members to POW status upon capture. See id. at 43. Yet an individual soldier's noncompliance (for example, by failing to wear the uniform or committing a war crime) divests him of POW status as an unlawful combatant, even while the group as a whole remains protected. See id. at 43-44. Similarly, an individual civilian's decision to personally take up arms and actively participate in hostilities (other than as part of a GCPW-compliant group) changes her status from noncombatant to unlawful 
enlistment in a state's military, necessarily also constitute becoming a combatant? Some argue in favor of such a conclusion. ${ }^{253}$

Or, as in civil wars, should direct involvement in hostilities by personally taking up arms be required? Those al Qaeda operatives who personally and directly prepare for and carry out terrorist attacks might be the analogue of rebel soldiers in a civil war who fight with guerilla tactics and blend into civilian populations. But what about other members of al Qaeda who play different and sometimes indirect roles in its overall mission of carrying out hostilities? In the traditional paradigm,

[f]or instance, a driver delivering ammunition to combatants and a person who gathers military intelligence in enemy-controlled territory are commonly acknowledged to be actively taking part in hostilities ... [, but] a mere contribution to the general war effort (e.g., by supplying foodstuffs to combatants) is not tantamount to active participation in hostilities. ${ }^{254}$

If the analogy holds, a person who provides weapons or operational support for a terrorist attack might similarly be seen as a combatant. But the fundraiser or

combatant. See id. at 27-31. The same analysis applies to individuals who become combatants by joining armed groups which are, as a whole, ineligible to provide lawful combatant status to their members-especially non-state forces engaged in noninternational armed conflicts or non-GCPW organizations in international armed conflicts. See id. at 44, 49 (arguing that all members of al Qaeda are unlawful combatants due to organization's non-compliance with GCPW); Watkin, supra note 106, at 34-37 (same).

${ }^{253}$ Justice Thomas in Hamdan argued not only that joining al Qaeda was sufficient to deem a person a combatant, but also that it constituted commission of a war crime:

Hamdan, a confirmed enemy combatant and member or affiliate of al Qaeda, has been charged with willfully and knowingly joining a group (al Qaeda) whose purpose is "to support violent attacks against property and nationals (both military and civilian) of the United States."

... [U]nlawful combatants, such as Hamdan, violate the law of war merely by joining an organization, such as al Qaeda, whose principal purpose is the "killing and disabling of peaceable citizens or soldiers."

Hamdan v. Rumsfeld, 548 U.S. at 693-94 (2006) (Thomas, J., dissenting) (quotation marks omitted); see also id. at 689 ("Hamdan is an unlawful combatant charged with joining and conspiring with a terrorist network dedicated to flouting the laws of war."); $i d$. at 692 ("Hamdan has been charged with conduct constituting two distinct violations of the law of war cognizable before a military commission: membership in a war-criminal enterprise and conspiracy to commit war crimes."). Justice Thomas also argued that Hamdan properly was charged based on his own personal conduct in conspiring to assist al Qaeda leaders in committing war crimes. See id. at 696-97. According to Justice Thomas, conspiracy to commit war crimes is itself a cognizable war crime. See id. at 697-704.

${ }^{254}$ DINSTEIN, supra note 107, at 27-28. 
propagandist - much less the food supplier or any other provider of "material support" to the organization generally ${ }^{255}$-would seem not to be a combatant because, while they contribute to al Qaeda's overall cause, they are not actively involved in the hostilities. Classifying which members of al Qaeda are combatants and which are not is crucial for determining who legitimately may be targeted by military force and who may be detained or prosecuted and punished under what standards. Yet the existing international laws of war fail to provide clear definitions of combatant and noncombatant status, especially when those concepts are sought to be applied to transnational terrorist organizations.

A second fundamental component of the existing laws of war is the threshold question of whether an "armed conflict" subject to the Conventions framework exists. Its definition is also left imprecise: "The problem is that the Geneva Conventions do not provide an authoritative definition of 'armed conflict.' Substantial evidence suggests, in fact, that the drafters of the Conventions purposely avoided any rigid formulation that might limit the applicability of the treaties. ${ }^{, 256}$ In the context of hostilities between states, the existence of a covered armed conflict is rarely called into doubt. ${ }^{257}$ But in noninternational armed conflicts, a state's sovereign interest in suppressing crime and internal violence frequently leads a government to deny the existence of an armed conflict subject to the laws of war, even when hostilities begin to closely resemble the sustained violence of civil war or even international war. ${ }^{258}$ Accordingly, in considering whether intrastate hostilities such as revolts or insurrections should be deemed to constitute an armed conflict, the crucial factors are whether the Government acknowledges the insurgency as a military threat, whether the Government recognizes the applicability of the laws of war, and whether the insurgents are organized in an endeavor to become an alternative government, possess a military

${ }^{255}$ Such persons are deemed combatants under the MCA, but that characterization is highly controversial and probably contrary to existing international law. See supra notes 212-215, 226-231 and accompanying text.

${ }^{256}$ Jinks, supra note 97, at 182-83 (emphasis added); see also MoIR, supra note 98, at 23-39 (discussing the drafting history of Common Article 3); Jinks, supra note 97, at 2132 (discussing the ambiguities of Common Article 3).

257 See Jinks, supra note 97, at 183 ("In the context of Common Article 2, this purposeful ambiguity has not presented significant difficulties. As discussed above [id. at 178-82], hostilities between states are, for the most part, governed by the Conventions irrespective of the intensity, duration, or scale of the conflict.").

${ }^{258}$ See id. at 183 ("[T] factual predicate for the operation of the laws of war in noninternational hostilities, should both reflect the humanitarian purposes of the Conventions and respect the national sovereignty of states. Balancing these often competing objectives is necessary because the international regulation of internal armed conflict is both necessary and potentially problematic."); see also GREEN, supra note 107, at 65-67 (discussing historical examples); MOIR, supra note 98, at 32-34 (discussing reasons states would deny the existence of armed conflict). 
structure, and agree to comply with the laws of war. ${ }^{259}$ Outside of the paradigmatic context of civil wars, similar issues are involved: the nature and extent of the hostilities and how the parties view them. ${ }^{260}$ Thus, whether intrastate violence will be subjected to the noninternational armed conflict provisions of the Conventions is a highly contextual—and highly political—determination.

Whether an armed conflict exists in the context of the violence carried out by al Qaeda and other transnational terrorist organizations is an even more vexing question. Technically, because al Qaeda is not a state, much less a signatory of the Conventions, the definition of an international armed conflict is not met. ${ }^{261}$ But Common Article 3 encourages states to apply the Conventions' international armed conflict rules in all conflicts. ${ }^{262}$ This provision strongly suggests that deeming a conflict to be international rather than noninternational-and thereby more subject to the Conventions, not less-should not be problematic, particularly if the United States were to bind itself to the full scope of the Conventions when its adversary does not. ${ }^{263}$ In addition, although the conflict with al Qaeda is not a typical intrastate or internal conflict subject to Common Article 3, that provision still applies to any armed conflict not covered by the international conflict rules. ${ }^{264}$

But is al Qaeda engaged in an "armed conflict" in the first place? By comparison to the factors examined in typical conflicts, a persuasive case can be made that the answer is yes, ${ }^{265}$ but some certainly would disagree. ${ }^{266}$ Regardless,

259 See Jinks, supra note 97, at 184-85 (quoting, citing, and discussing the interpretation of Common Article 3 set forth in INTERNATIONAL COMMITTEE OF THE RED Cross, 3 The Geneva Conventions of 12 August 1949: Commentary 35-36 (Jean S. Pictet ed., 1958) [hereinafter COMMENTARY]); see also MOIR, supra note 98, at 34-45 (discussing factors which identify an internal armed conflict subject to the laws of war).

${ }^{260}$ See Jinks, supra note 97, at 186 ("Noninternational hostilities constitute 'armed conflict' within the meaning of the Conventions if (1) the conditions pose an aggravated threat to core humanitarian values (an objective standard); or (2) the state party to the hostilities interprets them as an 'armed conflict' (a subjective standard)."); see also MoIR, supra note 98, at 46-52 (discussing situations in which armed conflict may become more international than non-international).

${ }^{261}$ See supra notes 124-125 and accompanying text; accord Jinks, supra note 97, at 178-82; Jinks, supra note 98, at 10-13; Murphy, supra note 145, at 1135.

${ }^{262}$ See GCCP, supra note 101, art. 3 ("The Parties to the conflict [not of an international character] should further endeavour to bring into force, by means of special agreements, all or part of the other provisions of the present Convention."); GCPW, supra note 101 , art. 3 .

${ }^{263}$ See Sloane, supra note 96, at 451-52, 483-85 (describing a "voluntarist" situation where states bind their conduct toward terrorists, despite terrorists' non-compliance with international law).

${ }^{264}$ See supra notes 169-172 and accompanying text. But see Murphy, supra note 145 , at 1135-36 (noting the objection that Common Article 3 is "a poor fit" for conflicts that are "transnational in scale").

${ }^{265}$ See Jinks, supra note 97 , at 187 . Jinks argues that: 
the nature of the threat posed by al Qaeda is so far removed from the paradigmatic situations contemplated in the Conventions framework that a new, specifically tailored definition of armed conflict is the optimal solution for clearly and unequivocally bringing transnational terrorist organizations within the coverage of the laws of war. ${ }^{267}$ Until such a definition achieves widespread acceptance or adoption in a treaty, however, the interpretative difficulties created by the existing Conventions framework will persist.

Determining whether an armed conflict subject to the Conventions framework exists is particularly difficult when the hostilities do not fit the traditional paradigm - for either interstate or civil wars - of continuous violence on discrete territorial battlegrounds. ${ }^{268}$ The 1949 Conventions addressed the problem of armed resistance to an enemy military force occupying territory of the state during an international armed conflict. ${ }^{269}$ Subsequently the 1977 Protocols sought to extend

The systematic application of these factors to the U.S. hostilities against al Qaeda strongly suggests that the "armed conflict" requirement is satisfied... [T] [Te United States does not assert that the characterization of the hostilities as a conflict undermines its sovereignty—indeed it has clearly chosen to respond to the group as a belligerent.... As evidenced by the attacks, al Qaeda is an armed group with the organizational capacity to engage in sustained hostilities on a global scale. Substantial evidence suggests that al Qaeda considered itself "at war," and that the attacks were part of an extended, escalating military campaign against the United States. The United States characterized the attacks as an "armed attack" and as "acts of war," and subsequently launched an international military campaign against al Qaeda and its supporters... These factors, considered in light of the values underlying Common Article 3, justify classifying the hostilities as an "armed conflict" within the meaning of the Geneva Conventions.

Id. See also Ní Aoláin, supra note 106, at 1555-60 (identifying the events of the September 11 attacks as initiating an armed conflict given their ferocity, "scale of destruction," and the "legal response" to the attacks); Jinks, supra note 97, at 182-87 (arguing that the hostilities between the U.S. and al Qaeda constitute an armed conflict).

${ }^{266}$ See Murphy, supra note 145, at 1135-36 \& nn.126-128 (citing various sources which argue that hostilities with al Qaeda do not rise to the level of an "armed conflict" for purposes of the Conventions).

${ }^{267}$ See Corn, supra note 238, at 299-300, 330-46 (proposing a new category of "transnational armed conflict" for situations involving "the extraterritorial application of military combat power by the regular armed forces of a state against a transnational nonstate armed enemy"); see also Berman, supra note 97, at 32-33 (acknowledging difficulties in applying existing Conventions framework); Murphy, supra note 145, at 1135-40 (same).

${ }^{268}$ See Berman, supra note 97, at 23-27.

${ }^{269}$ See id. at 19-20, 24-25 \& n.56; see also GCCP, supra note 101, arts. 4-6, 11, 2734, 47-78 (explaining the rules and guidelines concerning the treatment of persons protected under the Convention who find themselves in the hands of enemy parties during times of conflict or occupation); GCPW, supra note 101, arts. 4, 10, 122 (similar provisions regarding prisoners of war). Common Article 2 provides that the four 
those principles in the context of decolonization and national liberation movements. ${ }^{270}$ In each of these contexts, the states drafting the treaties struggled with the reality that such hostilities have both spatial and temporal discontinuities as compared with the traditional paradigm. ${ }^{271}$ For example, resistance to wartime invaders or colonial occupiers rarely takes place on identifiable battlefields. ${ }^{272}$ Likewise, while resistance may be sustained over a prolonged period of time, it often does not constitute a condition of continuous military hostilities. ${ }^{273}$ An armed conflict can exist so long as the hostilities constitute "protracted armed violence between governmental authorities and organized armed groups,"274 but armed conflict does not exist merely in "situations of internal disturbances and tensions, such as riots, isolated and sporadic acts of violence[,] and other acts of a similar nature." 275 Somewhere between "protracted" and "sporadic" lies the indeterminate threshold of armed conflict.

The spatial and temporal divergences from the traditional Conventions' paradigm are even greater in the context of transnational terrorist organizations.

Conventions "shall ... apply to all cases of partial or total occupation of the territory of a High Contracting Party, even if the said occupation meets with no armed resistance." GCCP, supra note 101, art. 2.

${ }^{270}$ See Protocol I, supra note 102, art. 1(3)-(4); Berman, supra note 97, at 21-23.

${ }^{271}$ See Berman, supra note 97, at 23 ("The spatial dimension concerns shifting control over territory; the temporal dimension concerns the episodic quality of the violence. These discontinuities make problematic the application of the key doctrinal distinctions that select certain forms of violence as the kind of combat entitled to international law privileges.").

${ }^{272}$ See id. at 25-26 ("[S]uch struggles are marked by 'the ubiquity of confrontation" in occupied or colonized territory. They may even be said to be wars 'without a front,' wars marked by the 'interpenetration and reciprocal encirclement' of the forces of occupiers and resisters." (translating and quoting MiCHEL VEUTHEY, GuÉRILla ET DROIT HuMANITAIRE $21(1983)))$.

${ }^{273}$ Id. at 26; see, e.g., id. at 27 (discussing Algerian resistance to French colonial occupation over a span of 130 years). Berman notes that:

The length of such occupations and the struggles against them, which may last decades or even centuries, defy the principles underlying the relevant international rules, which presuppose a relatively short occupation. Moreover, regardless of length, such struggles often go through a variety of phases, involving greater or lesser resemblance to military conflict, ranging from organized to disorganized actions, from violent to non-violent confrontations, from war-like periods marked by high-intensity violence to less turbulent periods marked by erratic violence, civil disobedience, or even relative quiescence.

Id. at 26.

274 Decision on the Defence Motion for Interlocutory Appeal on Jurisdiction, Prosecutor v. Tadic, Case No. IT-94-1-1, \& 70 (Oct. 2, 1995), available at http://www.un.org/icty/tadic/appeal/decision-e/51002.htm.

${ }^{275}$ Protocol II, supra note 102, art. 1(2). 
The closest analogy probably is to resistance fighters, ${ }^{276}$ but with terrorists the discontinuities are more extensive. Al Qaeda directs its hostilities at numerous countries around the world, so its "battlefield" is not limited even to the generalized territorial location where resistance fighters live and oppose invading or colonial occupiers, but it might rather be seen as comprising the entire territory of all its target nations. ${ }^{277}$ Alternatively, an armed conflict between the United States and al Qaeda might exist only where the United States actually deploys its own military forces in active combat status against al Qaeda and its allies, but not elsewhere-the position taken by a panel of the Fourth Circuit in al-Marri. ${ }^{278}$ Similarly, al Qaeda poses a continuous threat of hostilities, but it launches its major attacks at unpredictable, "episodic" intervals of months or even years. ${ }^{279}$ Are al Qaeda's intermittent attacks "protracted" enough to qualify as armed conflict? Or are they merely "sporadic" violence insufficient to invoke the laws of war at all? $?^{280}$ The existing laws of war struggle to answer such questions in traditional situations like intrastate violence, which may or may not be a civil war subject to the Conventions framework. When it comes to transnational terrorist organizations, the answers are even further from clear.

Finally, a foundational concept underlying the existing Conventions framework is the principle of the "equality of belligerents," which insists that all parties to a conflict should be entitled to the protections of the laws of war, irrespective of the legitimacy or justifiability of their role in initiating hostilities in the first place. ${ }^{281}$ For example, soldiers fighting in service to a state responsible for

${ }^{276}$ Berman, supra note 97, at 33 ("This quality of a discontinuous, yet protracted, conflict, ill-suited to the traditional categories, makes it akin to anti-occupation and anticolonial struggles.").

${ }^{277}$ See, e.g., Neal Richardson \& Spencer Crona, Detention of Terrorists as Unlawful Combatants and Their Trial by American Military Commissions, in LAW IN THE WAR ON INTERNATIONAL TERRORISM 123, 147 (Ved P. Nanda ed., 2005) ("The very nature of international terrorism makes 'the battlefield' anywhere and everywhere. The terrorist seeks to find soft civilian targets in the homeland as well as military targets overseas.").

${ }^{278}$ See supra note 198 (describing the al-Marri court's reasoning).

${ }^{279}$ See Berman, supra note 97, at 23 (describing the temporal discontinuity issue as one of "episodic" violence); Sloane, supra note 96, at 453, 485 (describing al Qaeda violence as "episodic").

${ }^{280}$ See Mary Ellen O'Connell, When is a War Not a War? The Myth of the Global War on Terror, 12 ILSA J. INT'L \& COMP. L. 535, 538 (2006) (suggesting that "al Qaeda's actions and our responses have been too sporadic and low-intensity to qualify as armed conflict").

${ }^{281}$ See Berman, supra note 97, at $5 \mathrm{n} .9,11-12$ (explaining the principle of equality of belligerents as signifying that the applicability of $j u s$ in bello, the international humanitarian law embodied in the Conventions governing the conduct of war, is independent from the determinations of jus ad bellum, governing the justifiability of states' resort to war); see also DINSTEIN, supra note 107, at 4-5 (noting that the law of international armed conflict "is predicated on the postulate of equal application of its legal norms to all parties"); Watkin, supra note 106, at 13-16, 67 (noting that the broader issues 
unlawfully launching an aggressive war receive equal treatment under the Conventions as those fighting for the state exercising its right of self-defense. ${ }^{282}$ Proposals to extend privileged combatant status to certain "noble causes" have proven highly controversial precisely because they weaken and undermine this principle. ${ }^{283}$

Yet the principle of equality of belligerents potentially carries undesirable implications if the laws of war are applied to transnational terrorist organizations. Under the principle, if the laws of war apply, then al Qaeda terrorists pursuing despicable purposes must be given the same legal consideration as, for example, prodemocracy guerillas fighting a civil war for the worthy goal of toppling a tyrannical despot. ${ }^{284}$ Therefore, keeping terrorists exclusively under the jurisdiction of domestic, criminal law might be preferable to many states if the alternative is that terrorists acquire a privileged combatant status as freedom fighters in wars of national liberation. ${ }^{285}$ The concern is not trivial: "There has been a gradual erosion of the concepts of resistance, freedom fighter, guerilla, and terrorist movements. The choice of term sometimes merely indicates the attitudes of the beholder." 286 For all its potential as a legal framework for addressing the threat of transnational terrorist organizations, the application of the laws of war is not without legal policy danger and political risk, as well.

of jus ad bellum have been separated conceptually from the law governing jus in bello, and that protections must be provided to all parties to an armed conflict without distinction).

${ }^{282}$ See DINSTEIN, supra note 107, at 4-5; Berman, supra note 97, at 11.

${ }^{283}$ See Berman, supra note 97, at 45-50 (contrasting the drafting of the 1949 Conventions, which rejected a Danish proposal for privileged status for civilians resisting illegal occupation despite the then-recent anti-Nazi resistance experiences, with the drafting of the 1977 Protocols, which provided privileged combatant status to certain kinds of irregular and guerilla forces fighting in wars of national liberation, leading some states to refuse to ratify the treaty); see also Protocol I, supra note 102, at pmbl. ("Reaffirming further that the provisions of the [four 1949] Geneva Conventions ... and of this Protocol must be fully applied in all circumstances to all persons who are protected by those instruments, without any adverse distinction based on the nature or origin of the armed conflict or on the causes espoused by or attributed to the Parties to the conflicts ... [.]").

${ }^{284}$ See Berman, supra note 97, at 28-29 (suggesting that "the combatants' privilege would be granted not only to arguably worthy forces such as armed pro-democracy militants, but also to those on the other side as well, such as armed anti-democracy forces"); see also id. at 29 (raising similar issues regarding "the actions against which such [United Nations-sanctioned military] operations are directed - such as terrorism, antigovernment and anti-UN violence, narco-militia operations, pre-2003 Iraqi attacks on 'coalition' forces, and so on").

${ }^{285}$ See, e.g., Beard, supra note 197, at 68-69 (arguing that "the continuing attempt to apply a model based on war instead of crime to suspected al Qaeda terrorists risks cloaking these individuals with legal trappings that increasingly resemble those of warriors instead of criminals").

${ }^{286}$ DETTER, supra note 107 , at 144. 
Thus, while the Geneva Conventions and the existing laws of war provide a powerful model for addressing the hostilities with al Qaeda, their applicability is far from clear and easy. The complexities in the Convention framework are difficult enough to resolve, even in the traditional situations for which it was designed. The difficulty in transposing the laws of war to the threat of transnational terrorist organizations is compounded by the undeniable reality that the Conventions simply were not designed with this form of hostilities and this contemporary threat in mind.

\section{DEFINING THE TERRORIST THREAT: INTEGRATING THE TwO MODELS}

These bodies of law provide two models, criminal and military, for defining the threat of terrorism. Each model presents different alternatives for pursuing the dual objectives of preventing terrorist attacks from occurring and punishing the individuals involved with terrorism, including planning or committing acts of terrorism or supporting the operations of terrorist organizations. The criminal and military models each have insights into the nature of the terrorist threat, as well as shortcomings in defining it. Similarly, both models struggle to balance the relative importance of personal conduct and group affiliation in addressing the threat posed by individual terrorists or particular conspiracies and the broader organizations of which they are a part. Neither model, standing alone, sufficiently covers all aspects of the problem.

Combining the criminal and military models into a unified framework, however, enables identification of which terrorists and individuals involved in terrorism should be treated as criminal defendants, and which should be deemed military enemies subject to military authority. Therefore, an integrated model is necessary to fully address the threat posed by al Qaeda and other transnational terrorist organizations.

\section{A. Prevention and Punishment Objectives}

Confronting the threat of terrorism involves the pursuit of two objectives: prevention and punishment. These objectives are related, but they are not always complementary. Prevention is an important goal, of course, because it is always better to stop a terrorist attack from occurring than for it to take place. Punishment of the perpetrators of completed acts of terrorism also is an important goal because it ensures that justice is done for the harm inflicted. But in the middle are many situations where both objectives are implicated. A terrorist cell may be arrested while still in the preparatory stages of their planned attack. Funds intended to support terrorist plots may be intercepted, or a conspiracy may be discovered shortly after its formation. Or terrorists armed and ready with a bomb may be foiled moments short of detonating their device. In each of these scenarios, charges may be filed based on the activities already undertaken, seeking to serve punishment as well as prevention objectives. 
The criminal model is, by nature, focused primarily on punishment objectives. The substantive criminal law defines offenses that punish conduct that has already taken place. ${ }^{287}$ That conduct may be the actual completion of a particular direct harm, or it may involve more preliminary activities, comprising inchoate or facilitation offenses. ${ }^{288}$ In each context, however, the criminal law specifies the nature of the proscribed conduct and determines the appropriate punishment for engaging in it. Punishment can be imposed only after that conduct, whatever it may be for a given offense, occurs.

The prevention objectives of the criminal model are, therefore, necessarily derivative of this punishment focus. Suspicious persons can be investigated in numerous ways prior to arrest, ${ }^{289}$ but the arrest itself can occur only once there is a crime to charge. ${ }^{290}$ Obviously, an arrest can be made prior to the commission of a completed crime-for example, murder — but the arrest nonetheless must be based on conduct constituting an attempted murder or a conspiracy to commit murder. ${ }^{291}$ Until the conduct reaches the level of a chargeable offense of some type, there can be no intervention by the criminal law; no matter how troubling or dangerous the individual appears, there is no prevention without some form of crime. ${ }^{292}$ Inchoate and facilitation offenses, therefore, allow the criminal model to serve the prevention objective by incorporating preliminary-stage conduct into the

${ }^{287}$ The Ex Post Facto Clauses of the U.S Constitution prohibit the imposition of criminal punishment for conduct which had not been criminalized at the time it occurred. See U.S. ConsT. art. I, $\S 9$, cl. 3 (federal); id. art. I, $\S 10$, cl. 1 (states); see also, e.g., Stogner v. California, 539 U.S. 607, 622-23 (2003) (holding that a statute purporting to revive a time-barred prosecution violates the Ex Post Facto Clause).

${ }^{288}$ See supra notes $14-17$ and accompanying text.

${ }^{289}$ Possible methods of investigation might include visual surveillance, wiretaps, or other electronic surveillance; the use of confidential informants; or grand jury subpoenas and search warrants of the suspicious or third parties.

${ }^{290}$ An arrest, with or without a warrant, must be based upon "probable cause" that a crime has occurred and that the person arrested committed it. See, e.g., Atwater v. City of Lago Vista, 532 U.S. 318 (2001); Dunaway v. New York, 442 U.S. 200 (1979). A subsequent indictment also requires probable cause that the defendant committed the charged offenses. See, e.g., United States v. R. Enters., Inc., 498 U.S. 292, 297 (1991).

${ }^{291}$ With respect to the facilitator, the crime of facilitation is completed once the facilitating conduct is engaged in with the requisite mens rea-e.g., providing funds to a known FTO. The facilitated person, however, does not commit a crime by receiving the facilitation, but rather can be charged only with an inchoate offense of attempt or conspiracy.

${ }^{292}$ See Chesney, supra note 47 , at 26-34 (describing tactics used by the Department of Justice to achieve prevention objectives using criminal law). See generally Robert Chesney, Anticipatory Prosecution in Terrorism-Related Cases, in THE CHANGING Role OF THE AMERICAN PROSECUTOR 157 (John L. Worrall \& M. Elaine Nugent-Borakove eds., 2008) (discussing how the Department of Justice has implemented terrorism-prevention goals). 
punishment structure itself. Thus, while the criminal model can be directed toward prevention, it is constrained by the ultimate focus on criminal punishment.

By contrast, the military model is focused primarily on prevention objectives. The purpose of military engagement is to defeat the enemy, thereby ensuring that the victorious party's goals are achieved and the vanquished party's are not. ${ }^{293}$ Those goals may vary from local skirmishes to geopolitical strategic power, but no matter the stakes, the purpose of preventing the enemy's success remains the same. In particular, the laws of war contemplate two significant methods of prevention: killing combatants fighting for the enemy, or incapacitating them. Combatants are legitimate targets for military force, and any combatant who continues to fight is constantly at risk of being killed during the hostilities. ${ }^{294}$ Combatants also may be captured, surrender, or otherwise cease to fight. ${ }^{295}$ These captured combatants may be detained by the opposing force, incapacitating them from further participation in the fighting. ${ }^{296}$ Whether they are targeted or detained, the objective is prevention: removing enemy combatants from the conflict.

The punishment objectives of the military model are derivative of the overall prevention focus. In international armed conflicts, and any noninternational armed conflict in which the affected state chooses to invoke the full scope of the Geneva Conventions, combatants who comply with the relevant rules are protected as lawful combatants with combatant immunity. Accordingly, such persons may not be punished at all by the opposing side, for the very reason that their actions during hostilities were privileged. ${ }^{297}$ Punishment, in international or noninternational conflicts, is reserved for two categories of persons: war criminals and unlawful combatants. ${ }^{298}$ War crimes are an offense against the rules of war, such as intentionally attacking civilians or engaging in perfidy. ${ }^{299}$ Any person who commits a war crime, regardless of whether that person otherwise would have been a lawful or unlawful combatant, is subject not only to incapacitation by detention, but also to punishment for violating the international rules of war. ${ }^{300}$ Similarly, combatants who fail to qualify as lawful combatants may be punished as well as detained. ${ }^{301}$ If they have committed no war crime, then unlawful combatants are not punishable for an offense against the rules of war. ${ }^{302}$ Unlawful combatants lack combatant immunity, however, so they may be punished by the capturing state

${ }^{293}$ Cf. CARL VON ClAUSEWITZ, ON WAR (1832) (variously translated, frequently as

"war is simply the continuation of politics by other means").

${ }^{294}$ See supra notes $107-108$ and accompanying text.

${ }^{295}$ See supra note 133 and accompanying text.

${ }^{296}$ See supra note 133 and accompanying text.

${ }^{297}$ See supra notes $133-136$ and accompanying text.

${ }^{298}$ See supra notes $137-139$ and accompanying text.

${ }^{299}$ See supra note 217 and accompanying text.

${ }^{300}$ Supra note 118 and accompanying text.

${ }^{301}$ See supra notes 137-139 and accompanying text.

${ }^{302}$ See supra note 160 and accompanying text. 
under its applicable criminal laws. ${ }^{303}$ Therefore, under the military model, punishment for war crimes is limited to those who exceed the acceptable bounds of warfare, while punishment of unlawful combatants simply involves denying individuals a laws-of-war privilege against ordinary prosecution.

Thus, the two models approach the threat of terrorism from opposite angles. The criminal model is concerned with punishing nefarious conduct, and achieves prevention only through the capacity to punish preliminary activity. The military model, on the other hand, is concerned with preventing enemy soldiers from achieving their goals through targeting and detention, while punishment of unprivileged combatants is secondary. In addressing the threat of terrorism, a balance closer to the middle of these two models is necessary.

\section{B. Insights and Shortcomings}

In defining the nature of the terrorist threat, each of the two models in its current form has insights and shortcomings. The insights provide useful guidance in shaping the legal framework for dealing with terrorists and indicate effective concepts that should be preserved. The shortcomings reveal ways in which the current models may be inadequate to fully address the threat and suggest problems that should be avoided in integrating the two models.

The insights of the criminal model flow from its focus on punishment. In particular, the criminal model is concerned with identifying the varying kinds and degrees of responsibility held by individuals involved in terrorism. ${ }^{304}$ The model identifies four kinds of responsibility for terrorist acts: completed crimes, inchoate attempted offenses, inchoate conspiratorial agreements, and separate facilitation crimes. It also identifies four degrees of responsibility: direct liability for personal participation, vicarious liability for personally aiding and abetting other persons, vicarious liability for object or Pinkerton offenses committed by others in furtherance of a conspiratorial agreement, and independent liability for facilitation. Nearly any combination of these categories could form the basis of criminal charges. ${ }^{305}$

In making these distinctions of kind and degree, the criminal model provides a framework to demarcate which individuals should be held responsible as "terrorists" and which individuals, despite their crimes, should not. In the categories of both kind and degree of responsibility, a sharp distinction is made between facilitation on the one hand, and the other three categories on the other.

${ }^{303}$ See supra notes $151-160$ and accompanying text.

${ }^{304}$ See supra Part II.A.

${ }^{305}$ See supra Part II.A. There is no "double facilitation" offense; that is, no existing offense proscribes person X's facilitation of person Y's $\S 2339 \mathrm{~B}$ offense of facilitating FTO Z. The other fifteen possibilities exist: for example, direct liability for an inchoate conspiracy, aiding and abetting an inchoate attempt, conspiracy to commit $\S 2339 \mathrm{~B}$ facilitation of an FTO, or facilitation of an FTO's activities culminating in a completed offense. 
Individuals who complete or attempt terrorist attacks are "terrorists" by any measure, and so too are individuals who intentionally join a conspiratorial agreement to plan and carry out a specific terrorism act. Such individuals will be convicted of criminal charges directly related to the relevant terrorism offenses. ${ }^{306}$ But a person who provides some form of material support to terrorists, with knowledge of who they are helping but with no actual involvement in specific plans, conspiracies, or attacks, is convicted for a crime of facilitation liability. ${ }^{307}$ That person is responsible as a "facilitator" for knowingly helping terrorists, but does not, under the criminal model, actually become a terrorist. Likewise, individuals who are directly liable for personal participation in terrorist crimes, or who are vicariously liable for such crimes based on their involvement with others, are "terrorists" under the criminal model. But a person whose involvement is attenuated at the point of general knowledge and who has no specific intention is not guilty of any actual terrorism offense; rather, he is guilty only of the independent crime of facilitation. He is a "facilitator" of terrorism but not actually, personally a terrorist.

Finally, the criminal model's distinctions among the kinds and degrees of responsibility, although focused on the punishment objective, provide insight into achieving the prevention objective. Completed offenses and nearly completed attempted offenses have little to do with prevention. But inchoate conspiracy liability extends responsibility far earlier in the course of conduct-practically to the point of the act of forming the conspiratorial agreement alone. ${ }^{308}$ And facilitation liability extends responsibility even further back than that, reaching persons who engage in generalized terrorism-support activity but nothing more. ${ }^{309}$ This signifies the judgment of the criminal model that the deep roots of terrorism must be dealt with, not just the final stages of terrorist activity. Similarly, vicarious liability for conspiracy-especially for Pinkerton offenses as well as object offenses - and facilitation liability for generalized support extend the scope of responsibility far beyond direct personal participation in, or personally aiding and abetting, terrorism offenses. ${ }^{310}$ This liability also strikes at the deep roots of terrorism, reaching all those who involve themselves with terrorists, even in the earliest stages. Thus, the criminal model displays a cognizance of the entire breadth and depth of the terrorist threat.

The criminal model also has its shortcomings, and these too flow from the focus on punishment. Existing U.S. federal criminal law, unsurprisingly, addresses terrorism primarily as a threat to be managed by law enforcement authorities and criminal prosecutions - just like the many kinds of activity condemned in the Criminal Code, such as child pornography, narcotics trafficking, and countless

\footnotetext{
${ }^{306}$ See supra notes 5-8, 14, 26-27 and accompanying text.

${ }^{307}$ See supra notes 45-58 and accompanying text.

${ }^{308}$ Supra Part II.A.2.; supra note 23 and accompanying text.

${ }^{309}$ Supra Part II.A.4.

${ }^{310}$ Supra Parts II.A.2., II.A.3.
} 
others. ${ }^{311}$ The legal reality is that many of the crimes charged against terrorists are not terrorism-specific offenses at all, but rather generally applicable crimes that happen to fit the facts. ${ }^{312}$ Although there are exceptions, such as $\S 2339 \mathrm{~B}$ and its emphasis on connections to FTOs, there is little in the criminal model that directly confronts what is distinctive about the threat of terrorists and the factors that distinguish them from the mine run of "regular" criminals like drug dealers, organized crime families, and porn peddlers. ${ }^{313}$ Accordingly, the criminal model fails to fully identify the scope of the threat or the nature of the harms inflicted, and largely understates the international dimensions of the problem. The criminal model therefore treats terrorism as merely one exceptionally despicable form of "ordinary" crime, when in fact it is something more.

The insights of the military model derive from its premise that the threat posed by al Qaeda and other transnational terrorist organizations has fundamental similarities to the armed conflicts already governed by the existing international laws of war. These similarities illustrate the ways in which the conflict with al Qaeda has elements that are substantially more "warlike" than any ordinary criminal threat. First, the kinds of attacks carried out by terrorists closely resemble traditional war crimes cognizable in armed conflicts governed by the laws of war. ${ }^{314}$ The targets of terrorist attacks often are civilians, because taking hostages or killing civilians going about their daily lives evokes the fear and outrage the terrorists seek to spawn. ${ }^{315}$ Terrorists attack indiscriminately, making no effort to strike only legitimate military targets or mitigate the effects on protected persons even when they do. ${ }^{316}$ Were such attacks carried out by a military force during an armed conflict, war crimes prosecutions would result. ${ }^{317}$ Second, terrorists carrying out these proscribed activities operate much like unlawful combatants under the

${ }^{311}$ See, e.g., 18 U.S.C. $\S \S 2252,2252$ A (child pornography); 21 U.S.C. $\S 841$ (2006) (narcotics distribution); id. $\S 848$ (continuing criminal enterprise); $i d . \S 960$ (narcotics trafficking).

${ }^{312}$ See supra notes 9-12 and accompanying text.

${ }^{313}$ It even fails to differentiate between terrorists and other criminals who launch violent attacks on governmental facilities:

It is important to note that the ICRC Commentary to Common Article 3 provides only one concrete example of activities not amounting to "armed conflict": a handful of individuals rebel against the state and attack a police station. The intensity, coordination, and pattern of al Qaeda attacks against the United States make clear that the September 11 attacks were not simply "mere acts of banditry."

Jinks, supra note 98 , at 37 (quoting COMMENTARY, supra note 259, at 34).

${ }^{314}$ See supra note 111 and accompanying text.

${ }^{315}$ See supra notes 220-222 and accompanying text.

${ }^{316}$ See MARK JuergenSMEYER, TERror IN THE Mind OF GOD: THE Global Rise OF RELIGIOUS ViOLENCE 121 (2000).

${ }^{317}$ See supra notes $223-225$ and accompanying text. 
laws of war: they do not wear uniforms or distinctive emblems to indicate their allegiance, nor do they bear arms openly to signify their active participation in hostilities. Instead, they conceal themselves among civilian populations, feigning noncombatant status and relying on that deception to make the perpetration of their attacks possible. ${ }^{318}$ Unlike even the guerilla fighters controversially privileged by the 1977 Protocol, ${ }^{319}$ terrorists do not reveal themselves as combatants even when they do actually take part in hostilities - they simply strike without warning. Thus, in mode and method of operation, terrorists have much in common with war criminals and unlawful combatants.

In addition, the organization and operation of al Qaeda and other transnational terrorist organizations has close similarities to armed groups engaged in traditional armed conflicts. Like the regular armed forces of a state, al Qaeda recruits and enlists members to its cause and trains them to carry out many kinds of violent attacks. ${ }^{320}$ Although it may lack the rigid institutionalism of state armies, al Qaeda does contain leadership and command structures not unlike more loosely organized irregular forces, militias, or organized resistance movements. ${ }^{321}$ In addition, al Qaeda has a division of labor much like an armed force: it has leaders and strategists, commanders and foot soldiers, members who actively engage in hostilities and members who play supporting roles. ${ }^{322} \mathrm{Al}$ Qaeda also has allies and supporters among nonmembers: persons who have not joined the group but who favor its cause and render support to the overall terrorist effort. ${ }^{323}$ Thus, al Qaeda has member terrorists who have the hallmarks of traditional combatants, and it has like-minded loyalists who would be deemed noncombatants in a traditional armed conflict.

Finally, the military model reflects several important aspects of how the parties involved-particularly the United States and al Qaeda - characterize their conflict. For their part, al Qaeda's leaders purport to be at war with the United States. ${ }^{324}$ Although the United State did not officially declare war on al Qaeda, the Congress did specifically authorize the use of the U.S. armed forces against al Qaeda. ${ }^{325}$ The international community similarly supported the validity of the United States' claimed right to exercise military self-defense against the al Qaeda

${ }^{318}$ Karen S. Seifert, Interpreting the Law of War: Rewriting the Rules of Engagement to Police Iraq, 92 MinN. L. REV. 836, 854 (2008).

${ }^{319}$ See supra notes 102, 165-166.

${ }^{320}$ See ROHAN GUNARATNA, INSIDE AL QAEDA 70-76 (2002).

${ }^{321}$ See id. at $54-60,95$.

${ }^{322}$ See id. at $54-60$.

${ }^{323}$ See id. at $60-70,77,226$.

${ }^{324}$ Supra note 240 and accompanying text.

${ }^{325}$ See Authorization for the Use of Military Force, Pub. L. No. 107-40, §2(a), 115 Stat. 224, 224 (2001) (stating that "the President is authorized to use all necessary and appropriate force against those... organizations, or persons he determines planned, authorized, committed or aided the terrorist attacks that occurred on September 11, 2001"). 
threat. ${ }^{326}$ And it is indisputable that the United States has deployed and exercised military force against al Qaeda targets around the globe. ${ }^{327}$ Thus, the military model conforms not only to the rhetoric of the conflict, but also to the reality of the hostilities between the parties. ${ }^{328}$

The shortcomings of the military model derive from the limitations intrinsic to the existing laws of war, because the threat posed by al Qaeda and other transnational terrorist organizations also has several fundamental dissimilarities to the paradigmatic armed conflicts contemplated by the Conventions framework. Although the acts of terrorism and nature of the al Qaeda organization closely resemble the conduct of, and some participants in, traditional armed conflicts, other aspects of the threat are divergent. The geographic scope of the threat is vast, without a paradigmatic battlefield openly fought over by armed forces in an interstate war, ongoing civil war, or even cyclical rebellion. ${ }^{329}$ The temporal scope of hostilities is difficult to quantify: a continuous threat that an attack could occur at any time, yet only intermittent actual violence; hostilities that are "protracted" over many years but arguably may be "sporadic" over any given time span. ${ }^{330}$ Even if the participants and actions of the conflict resemble the paradigm, the when and where do not. This profound difference from the existing concepts of "armed conflicts" calls into question the validity of transposing other aspects of the laws of war to the terrorist threat when the foundational premise for applying the laws of war in the first place may not exist.

Another feature intrinsic to the existing laws of war also presents a potential shortcoming to the military model. Under the principle of equality of belligerents, the application of the laws of war does not depend on the rightness or wrongness of the cause for which a combatant fights. ${ }^{331}$ Soldiers in an army fighting a clearly illegal, aggressive war remain eligible for protection as lawful combatants; soldiers who fight as unlawful combatants, with no pretense of complying with the

${ }^{326}$ See Jinks, supra note 98, at 35-37 (describing actions taken by the United Nations, NATO, and the Organization of American States).

${ }^{327}$ See, e.g., Jinks, supra note 97, at 187 ("Military operations directed against al Qaeda and its affiliates have continued to the time of this writing [in 2005] - currently ongoing in Afghanistan, the Philippines, Colombia, and several countries in the Horn of Africa.").

${ }^{328}$ Berman, supra note 97, at 33 ("One could ... categorize[e] Al-Qaeda['s] attacks as purely criminal and the response as law-enforcement activities that should be closely disciplined by domestic civil liberties law and international human rights law. This categorization would, however, defy the way all parties to the struggle conduct and define it. It would also take one of the key armed conflicts of our time, conducted by military means, out of the jurisdiction of the laws of war.").

${ }^{329}$ See supra note 261.

${ }^{330}$ See supra notes 276-277; cf. supra notes 271-275 and accompanying text (discussing factors identifying an internal armed conflict).

${ }^{331}$ See Berman, supra note 97 , at $5 \mathrm{n} .9,11-12$; see also supra text accompanying note 281 (explaining the principle of equality of belligerents). 
requirements of lawful combatants, remain entitled to lesser protections under the Conventions. ${ }^{332}$ Yet the existing paradigm does not contemplate an armed force devoted to the commission of war crimes, the members of which have no interest in ever complying with the rules of war but only in committing acts of terrorism. It is one thing to invoke the equality of belligerents in international conflicts or internal insurrections, where the justice of either cause may be simply in the eye of the beholder - and where beholders will be found both inside and outside the conflict. It is another thing entirely to invoke it on behalf of al Qaeda and other transnational terrorist organizations, which are universally condemned by civilized nations. ${ }^{333}$ Even if their cause otherwise might be morally ambiguous or even noble, ${ }^{334}$ their methods and their repudiation of any intention to comply with the rules of war divest terrorists of any moral standing. Consequently, to apply the equality of belligerents to terrorists may be a politically and legally intolerable step too far down the path of moral equivalency.

Thus, the criminal and military models each have insights and shortcomings in defining the nature of the terrorist threat. Neither model, standing alone, addresses the threat fully and satisfactorily. But taken together, they provide the conceptual tools for solving their respective problems. An integrated model takes the best parts of each, and best addresses the issues involved.

\section{Balancing the Significance of Personal Conduct and Group Affiliation}

The confrontation with terrorism exists on two levels: the dangers posed by individual terrorists and the particular activities they personally undertake, and the threat posed by transnational terrorist organizations and the aggregate activities of the group as a whole. The criminal and military models both address these two aspects, seeking to strike the right balance between personal conduct and group affiliation in defining terrorism.

When addressing an individual's direct, personal participation in terrorist activity, the models are in basic agreement that holding the individual responsible for the consequences of his personal conduct is justifiable and appropriate. In the criminal model, a person may be convicted of a completed or attempted crime in which she directly took part; a person also is guilty of the inchoate offense of

${ }^{332}$ See DINSTEIN, supra note 107, at 29-33; Berman, supra note 97, at 13-15; Jinks, supra note 102, at 379; see also supra text accompanying note 139 (describing the limited protections offered to unlawful combatants under the Conventions).

${ }^{333}$ Cf. S.C. Res. 1368, ๆ 1, U.N. Doc. S/RES/1368 (Sept. 12, 2001) (stating that the Security Council " $[u]$ nequivocally condemns in the strongest terms the horrifying terrorist attacks ... which took place on 11 September 2001 in New York, Washington, D.C. and Pennsylvania and regards such acts, like any act of international terrorism, as a threat to international peace and security").

${ }^{334}$ Cf. Berman, supra note 283, at 23-31 (discussing Protocol I's application to wars of national liberation and similar causes). 
conspiracy when she personally joins the conspiratorial agreement. ${ }^{335}$ In addition, a person is guilty of an offense she did not personally commit if she nonetheless directly and personally aided and abetted its commission by others. ${ }^{336}$ Similarly, in the military model, an individual who takes up arms and personally participates in hostilities is a combatant. ${ }^{337}$ An individual's own personal conduct also may serve as the basis for classifying him as an unlawful rather than lawful combatant, such as when the individual soldier fails to comply with the principle of distinction. ${ }^{338}$ And an individual who personally participates in a violation of the rules of war, or who personally and substantially aids and abets a violation by others, may be prosecuted and punished for his completed war crimes. ${ }^{339}$ Thus, under either model, assessing a person's fate based on her own direct, personal conduct is not problematic.

The models begin to diverge when addressing the extent to which individuals are responsible for the consequences of their membership in a group. In the criminal model, all the members of a conspiratorial agreement are held vicariously liable for offenses committed in furtherance of the agreement by any one or more of them. ${ }^{340}$ This includes not only the specifically agreed to object offenses but also any reasonably foreseeable Pinkerton offenses. ${ }^{341}$ At least with respect to particular conspiratorial groups, therefore, an individual's responsibility is extensive. And members of a terrorist organization who provide generalized assistance toward the organization's objectives, but are not involved in any particular conspiratorial agreement and therefore have no vicarious liability, nevertheless can be convicted of facilitation offenses. ${ }^{342}$

In the military model, by contrast, responsibility for group membership is more constrained. Membership in certain forms of armed groups may determine a person's status as a combatant per se, or as an unlawful combatant per se, because the characteristics of the group itself are dispositive on the relevant criteria. ${ }^{343}$ Beyond the possible determination of combatant status, however, the individual does not incur responsibility for group membership. ${ }^{344}$ Most importantly, there is

${ }^{335}$ See supra notes $2-23$ and accompanying text.

${ }^{336}$ See supra notes $24-30$ and accompanying text.

${ }^{337}$ See supra note 120 and accompanying text.

${ }^{338}$ See supra note 263.

${ }^{339}$ See supra notes $123-125$ and accompanying text.

${ }^{340}$ See supra notes $25-30$ an accompanying text.

${ }^{341}$ See id.

${ }^{342}$ See supra notes 55-56 and accompanying text.

${ }^{343}$ For example, all persons who are members of the regular armed forces of a state are combatants, regardless of their own actual role in the group. See supra note 114 and accompanying text. Likewise, all persons who take part in hostilities as part of an armed group without uniforms and emblems or command responsibility are unlawful combatants because the group's non-compliance with GCPW requirements makes eligibility for lawful combatant status impossible. See supra note 252.

${ }^{344}$ See Danner \& Martinez, supra note 119 , at 114. 
no vicarious liability for war crimes based on membership alone; some extent of individual participation is required. ${ }^{345}$ Unlike the criminal model's conspiracy, in the military model, individuals are not held personally accountable for the specific actions or misdeeds of other members of the armed group to which they belong.

Finally, the two models diverge significantly when addressing the implications of an individual's loose affiliation or loyalty to a group of which he or she is not a member. In the criminal model, facilitation liability reaches those individuals who knowingly provide material support to terrorist organizations but who lack any form of direct knowledge, purpose, or participation regarding any specific terrorist objectives required to establish a conspiracy. ${ }^{346}$ Individuals who are not members of a terrorist organization can be convicted for facilitation just as members can be, so long as they have the required actus reus and mens rea. Thus, individuals who will never personally participate in anything remotely resembling a terrorist attack, and who are not members of any terrorist group, nevertheless are held criminally responsible for providing support to a group whose general objectives they favor.

In the military model, on the other hand, such ties are insufficient to affect the individual's status or responsibility. Only taking up arms, whether individually or as part of an armed group, makes a person into a combatant. ${ }^{347}$ Absent some involvement in the conduct of hostilities, a person remains a noncombatant; that is, a noncombatant may render material support to combatants without being one. ${ }^{348}$ Likewise, there is no vicarious or facilitation liability for rendering general support to a group that engages in war crimes; accountability requires personal involvement in specific crimes. ${ }^{349}$

Thus, although there are some similarities in the ways the criminal and military models balance personal conduct and group affiliation, there also are significant differences. These differences provide further reason to integrate the two models in defining the terrorist threat.

\section{Consequences: Military Enemies and Criminal Defendants}

The threat posed by al Qaeda and other transnational terrorist organizations challenges both existing models. The criminal model fails to account for the ways terrorism more closely resembles war than ordinary crime. By contrast, the military model fails to account for the stark disparities between the terrorist threat

${ }^{345}$ See, e.g., id. at 127-28 (explaining that command liability is not a form of strict liability or vicarious liability).

${ }^{346}$ See supra notes $45-48$ and accompanying text.

${ }^{347}$ Supra notes $114-117$ and accompanying text.

${ }^{348}$ See supra notes $115,212-214$ and accompanying text. For example, involvement with weapons of war or military espionage qualifies as participation in hostilities but rendering other forms of non-combat, "ordinary" assistance to combatants does not. See supra note 254 and accompanying text.

${ }^{349}$ Supra note 123 and accompanying text. 
and the traditional forms of armed conflict. Standing alone, neither model adequately defines the terrorist threat. ${ }^{350}$ An integrated model, incorporating the best insights and bolstering the shortcomings of each, is necessary to fully define this threat.

The terrorist threat presents such a great challenge to the existing models because al Qaeda is an entity far different from the paradigms at their cores. To compare al Qaeda terrorists to local street gangs menacing a neighborhood or armed bank robbers who initiate a shootout with police ignores the coordination and resources al Qaeda devotes to carrying out a pattern of large-scale, highintensity attacks. ${ }^{351}$ To compare al Qaeda to the regular armed forces of a state, or even irregulars or militias, ignores not only the diffuse geographical and organizational aspects of the group, which lacks the strict hierarchies and clearly delineated membership rosters of traditional military forces, but also the equally diffuse aspects of the conflict it wages, which is spatially and temporally unpredictable and intermittent. ${ }^{352}$ Some organized crime families or drug trafficking conspiracies may have extensive coordination and resources, and some armed groups engaged in armed conflicts of resistance or insurrection may have an amorphous membership. But such entities do not have as their constitutive purpose the goal of waging war against the civilian populations of "enemy" nations deliberately and expressly by means and methods of war crimes. Thus, an integrated model is needed to define the al Qaeda threat.

The most effective way to define the nature of the threat is to determine when, how, and why any given individual should be deemed to be part of the overall al Qaeda terrorist threat. There are four possible categories of individuals who might be held responsible as "terrorists." Examining each category from the perspective of integrating the two models identifies the applicability and limits of each.

The broadest category would deem an individual to be a terrorist based upon simple affiliation with al Qaeda, such as an oath of allegiance or a pledge of loyalty. In other words, it is enough simply to carry a membership card, or whatever its al Qaeda equivalent may be.

Both models suggest that this category is overbroad, so the integrated model rejects it. The criminal model does not punish membership as such, in the sense of

${ }^{350}$ Cf. Berman, supra note 97, at 33 ("No matter which body of law one chooses, to place this conflict within its sole jurisdiction seems to expand its conceptual framework beyond reasonable bounds.").

${ }^{351}$ See Jinks, supra note 98, at 37 ("The intensity, coordination, and pattern of al Qaeda attacks against the United States make clear that the September 11 attacks were not simply "mere acts of banditry." (citing COMMENTARY, supra note 259, at 35)); see also Berman, supra note 97, at 57 (" $[\mathrm{T}]$ he maintenance of the legal construction of war requires that we distinguish between combatants and criminal gangs, between people 'captured in combat' and people 'arrested after a shootout with police,' with the unprivileged combatant category a byproduct of the always contestable character of such distinctions.").

${ }_{352}$ See supra notes $242,245,277,279$ and accompanying text. 
pure affiliation or loyalty. ${ }^{353}$ It might be possible to draft a membership offense to meet the constitutional requirements of the First Amendment, but Congress has not done so. ${ }^{354}$ This is unsurprising, due to the breadth of the facilitation offenses: a fact pattern of mere membership, unaccompanied by anything further, rarely will arise - and does not warrant criminal punishment if it does. ${ }^{355}$

The issue of simple affiliation is more complex in the military model, where the question is whether al Qaeda qualifies as an armed force whose members are combatants per se. While certain aspects of al Qaeda resemble a military force engaged in armed conflict, other aspects do not. Given the ambiguities in its characteristics, one conclusion is clear: it cannot be said definitively that al Qaeda is directly comparable and equivalent to a traditional armed force. This suggests that the military model, on its own terms, weighs against per se combatant status. The contribution of the criminal model to the analysis tilts the scales even further,

${ }^{353}$ Even the facilitation offenses do not reach pure membership disconnected from any additional activity or intent. The $\S 2339 \mathrm{D}$ offense proscribes engaging in military-type training for an FTO, which is a commitment of time and action beyond simple allegiance. See supra note 57 and accompanying text. Similarly, the $\S 2339 \mathrm{~B}$ offense includes "personnel," including "providing" oneself, as a form of proscribed "material support or resources" to an FTO. See supra notes 49, 58 and accompanying text. The plain meaning suggests that mere loyalty is not covered, but rather that a person is "provided" to an FTO only when they will serve an instrumental function as "support" or "resources" for the organization, just as other listed "resources" like property, service, money, transportation, lodging, expert advice, and weapons also are instrumental. See supra notes 48-49 and accompanying text. A mere pledge of loyalty, unaccompanied by any other commitment of action or intent, does not "provide" any usable "resource" or "support" to the FTO. In any event, it does not appear that the Government has sought to charge $\S 2339 \mathrm{~B}$ on a theory of pure membership. See Chesney, supra note 47, at 68-71.

${ }^{354}$ See Chesney, supra note 47, at 66-71. In Scales v. United States, the U.S. Supreme Court upheld a conviction under the Smith Act, which had criminalized membership in the Communist Party, against Due Process and First Amendment challenges. See Scales v. United States, 367 U.S. 203, 220-30 (1961) (interpreting and applying 18 U.S.C. § 2385). The Scales Court "identified two constitutionally required elements that must be present in order to criminalize membership itself": that "the defendant was not merely a passive but an active member of the organization" and "not only knew of but also specifically intended to facilitate the organization's unlawful ends," which in the case of the Communist Party was the violent overthrow of the U.S. government. Chesney, supra note 47 , at 68 (discussing Scales, 367 U.S. at 220-28; see also NAACP v. Claiborne Hardware Co., 458 U.S. 886, 920 (1982)) ("For liability to be imposed by reason of association alone, it is necessary to establish that the group itself possessed unlawful goals and that the individual held a specific intent to further those illegal aims."). A similar offense could be enacted in the context of terrorism, proscribing active membership in al Qaeda or another transnational terrorist organization with specific intent to contribute to the commission of acts of terrorism by the group. See Chesney, supra note 47, at 81-82.

${ }^{355}$ That is, the risk posed by the individual is so attenuated from the harms threatened by al Qaeda as a whole that Congress has determined that criminal punishment is not warranted. 
because it also counsels against heavy consequences for mere affiliation. Accordingly, when the two models are integrated, the assertion that all members of al Qaeda are combatants per se, necessarily and by reason of members alone, must be rejected. Absent further, additional conduct on their part, members of al Qaeda are noncombatants - and they are not criminals. An individual's allegiance or loyalty to al Qaeda may be morally or politically troubling, but it should, by itself, have no legal consequences. Such a person may be a terrorist sympathizer, but she is not, without more, a terrorist.

By contrast, the narrowest category deems an individual to be a terrorist only if he or she personally had direct involvement in the commission of a completed terrorist attack. This category includes the persons who actually carried out the attack, as well as those who aided and abetted it by personally assisting in the planning or implementation of the offense. In addition to those active operatives, the al Qaeda commanders and strategists who ordered, directed, managed, or assisted the commission of an attack by their subordinates also fall into this category.

The integrated model unequivocally allows such persons to be treated as combatants who are military enemies subject to military authority. In the criminal model, they could be convicted and punished for their roles in the completed crimes that apply to the attack carried out. That is, the military model is not necessary to deal with this category. Nevertheless, it is available-and appropriate. Unlike many of the difficult questions about how the military model applies to al Qaeda, classifying these persons as combatants is not complicated or ambiguous. By personally taking part in hostilities, they have forfeited their noncombatant status. As combatants, they may be targeted by military force or detained as military prisoners. ${ }^{356}$ By personal involvement in a completed attack, they also have become responsible for a war crime under the rules of war, for which they are subject to punishment in a military proceeding. ${ }^{357}$ The application of the laws of war and the military model to individuals in this category is straightforward. Thus, the integrated model deems them to be terrorists who qualify as combatants and war criminals, and who may be treated accordingly under military authority.

The two remaining categories fall between these two poles on the spectrum of involvement and participation in terrorist activities and organizations. One category, somewhat narrower than mere membership, would deem an individual to be a terrorist if he or she renders generalized assistance to al Qaeda's overall endeavor. Affiliation alone is not enough; rather, some quantity of support or aid to

\footnotetext{
${ }^{356}$ See supra Part III.A.1.
}

357 See supra notes 110-111, 118-121 and accompanying text. As unlawful combatants, such persons do not possess combatant immunity. See supra notes 114, 160 and accompanying text. This simply means, however, that they are eligible for prosecution and punishment under the criminal model for whichever offenses are applicable to their conduct during hostilities. 
the terrorist organization is needed. Yet the person need not know about, prepare for, or take part in any particular al Qaeda operation or terrorist attack. Support for the general operational activities of al Qaeda is sufficient.

The integrated model allows for the punishment of this category of individuals through the criminal law, but it does not allow them to be subjected to military authority. The criminal model already defines and punishes this conduct as facilitation. Persons convicted for facilitation liability do not acquire any liability for crimes related to participation in terrorist activities. ${ }^{358}$ Rather, the lack of more specific knowledge or action renders them liable for the extent of their own conduct: knowingly providing support to the generalized efforts of terrorists. Under the military model, by contrast, facilitation is not a basis for attributing combatant status to someone who otherwise is a noncombatant. ${ }^{359}$ Facilitating a terrorist organization generally is too far removed from personally taking up arms in hostilities. Accordingly, the military model clearly counsels in favor of facilitators remaining noncombatants. They remain subject to criminal prosecution for the relevant facilitation crimes, of course, but they are not military enemies. Thus, while these individuals are responsible for supporting terrorists, they do not actually become terrorists themselves.

The final category applies to anyone more involved in terrorism than a facilitator and who, therefore, has some degree of personal involvement in specific terrorist activities. This category potentially includes a wide range of individuals, from those who directly participate in attempted offenses to those who are a small piece in a large conspiracy puzzle. What the persons in this category have in common, however, is some identifiable personal participation in particular terrorist plots, above and beyond generalized involvement or support.

The last category is the most difficult for the integrated model to resolve, because it involves those situations with the greatest divergence between the criminal and military models. The criminal model defines and punishes offenses applicable to the full range of conduct in this category. Inchoate liability for attempt reaches plots that are thwarted just short of completion, while inchoate liability for conspiracy punishes the formation of the agreement to plan and commit an attack. ${ }^{360}$ Vicarious liability extends well beyond personally aiding and abetting to all object and Pinkerton offenses of the conspiracy, completed or attempted by any member of the group, even when an individual conspirator had no personal involvement at all in the planning or commission of those offenses. ${ }^{361}$ Criminal liability, therefore, is extensive.

The military model, on the other hand, has much more ambiguous applicability. Without a completed terrorist attack there is no war crime, so the

\footnotetext{
${ }^{358}$ See supra note 47 and accompanying text.

359 See supra notes $114-115,117$ and accompanying text.

${ }^{360}$ See supra notes 16,22 and accompanying text.

${ }^{361}$ See supra notes 25-30 and accompanying text.
} 
military model itself provides no basis for punishment. ${ }^{362}$ To the extent these persons are deemed noncombatants, they remain subject to the criminal model anyway. ${ }^{363}$ Hence, the question is whether some or all of the individuals in this category should be deemed combatants because their conduct is tantamount to personally taking up arms in hostilities-specifically, as unlawful combatants taking part in the hostilities carried out by al Qaeda in its armed conflict with the United States. ${ }^{364}$ As unlawful combatants, they would not possess combatant immunity; thus, to the extent they are prosecuted and punished, their responsibility comes from the bases of liability provided in the criminal model. ${ }^{365}$ This does not mean, however, that unlawful combatant status would have no consequences. As combatants, these persons would be subject to targeting by military force and detention as military prisoners. ${ }^{366}$ They also could be subject, unlike noncombatants, to prosecution and punishment for their crimes in a military proceeding, rather than civilian courts. ${ }^{367}$ Therefore, the crucial determination is which, if any, of the individuals in this category should be deemed unlawful combatants subject to military authority.

The integrated model resolves this difficult question by concluding that only a narrow subset of the individuals in this category should be deemed military enemies rather than criminal defendants. Only those persons who are members of a specific al Qaeda terrorist plot which poses the danger of an imminent terrorist attack are subject to military authority. All other persons in this category are subject to criminal prosecution for their crimes, but they may not be removed from the ordinary civilian legal regime.

This narrow definition of military enemies follows from integrating the existing criminal and military models. Under the criminal model, liability is extensive for persons who have varying degrees of personal involvement in specific terrorist activities above and beyond the generalized support punishable as facilitation. But that liability comes from ordinary criminal law. The breadth and depth of liability does not, standing alone, authorize any extraordinary treatment of terrorists - after all, the extensive criminal liability rules applicable to terrorists are equally applicable to all other criminals, such as drug traffickers, organized crime syndicates, or identity thieves. ${ }^{368}$

The argument for exceptional treatment for terrorists comes from the military model and the analogy of terrorists to combatants in an armed conflict. As

${ }^{362}$ See supra note 122.

${ }^{363}$ See supra notes $135,159,166-167,302,356$, and accompanying text (describing combatant immunity from ordinary criminal prosecution possessed by lawful combatants, and corresponding lack of immunity from ordinary criminal prosecution for unlawful combatants and noncombatants).

${ }^{364}$ See supra note 252.

${ }^{365}$ See supra note 303 and accompanying text.

${ }^{366}$ See supra notes $107-108$ and accompanying text.

${ }^{367}$ See supra note 114 and accompanying text.

${ }^{368}$ See supra note 313 and accompanying text. 
explained above, the integrated model rejects the claim that membership in al Qaeda, as such, imputes to an individual combatant status per se. ${ }^{369}$ Under the military model in its current form, therefore, the alternative definition of combatant status is very narrow-personally taking up arms in hostilities. There is no inchoate combatant status or vicarious combatant status. Individuals are combatants when they are directly involved in the conduct of hostilities by participating in armed combat or providing operational support such as weapons or intelligence to those who do. All other persons are noncombatants, even those who provide direct support to noncombat aspects of the war effort. ${ }^{370}$

The integrated model accommodates these competing frameworks in a new model, which adapts aspects of each to the distinct threat posed by al Qaeda and other transnational terrorist organizations. Expanding unlawful combatant status to all persons responsible for terrorism offenses in the criminal model ignores the important contribution of the military model. In less structured, more diffuse conflicts like insurrections, civil wars, and terrorism, a high degree of personal participation should be necessary to deem an individual to be an active combatant at risk of reciprocal military violence, rather than a noncombatant subject to civilian treatment and ordinary criminal law. Similarly, limiting unlawful combatant status exclusively to those currently covered by the military model ignores the significant contribution of the criminal model. In the context of the threat of al Qaeda, terrorists who are on the cusp of committing a terrorist attack create equally grave social harms and are deserving of punishments with severity equal to those who actually carry out an attack. ${ }^{371}$

Integrating the two models, therefore, requires relaxing the stringent standard of the existing military model to encompass the most dangerous threats identified by the criminal model. First, terrorist unlawful combatants should include individuals whose conduct fits the definition of attempt liability. But for being thwarted by authorities or their own failures, such individuals would have carried out their planned attack and committed completed offenses. The fortuity that they failed to engage in their intended actual hostilities should not grant them the windfall of noncombatant status, given that they clearly would have been combatants had their intended-nearly successful—plot been carried out to

${ }^{369}$ See supra notes $350-368$ and accompanying text. Thus, to the extent that terrorists are comparable to traditional combatants, the better comparison is to participants in a noninternational armed conflict, rather than the more organized armed groups in an international conflict. See supra notes 252-253.

${ }^{370}$ See supra note 254 and accompanying text.

${ }^{371}$ The only substantial limitation is that the death penalty is not available if no deaths have resulted from the defendant's conduct; life sentences are available, however, for many conspiracy offenses charged in terrorism cases. See, e.g., 18 U.S.C. § 956(a)(2)(A) (2006) (conspiracy to commit murder abroad); id. $\S 1117$ (conspiracy to commit murder within federal jurisdiction); id. $\S 2332 \mathrm{a}$ (conspiracy to use weapon of mass destruction); id. $\S$ $2332 \mathrm{~b}$ (conspiracy to engage in conduct transcending national boundaries which kills persons). 
completion. Such individuals are so close to having engaged in actual hostilities that they should be treated equivalently to those who do.

Second, terrorist unlawful combatants also should include persons whose conduct has not reached the full extent of attempt liability, so long as the intended terrorist attack is imminent. An attack is imminent in situations where the terrorists have not yet set out to commit their attack, but where it is ready for commission and can be carried out at any time of their choosing. An attack is imminent, therefore, when planning and preparation are completed and the only factor not yet present is the decision-or order-to go forward. As with attempted attacks, persons ready to carry out an imminent attack are fully committed to engaging in actual hostilities but have not yet done so only due to a fortuity of timing, such as being arrested or captured before they could. They too are so close to having engaged in actual hostilities that they should be treated equivalently as those who did.

Third, this expanded scope of terrorist unlawful combatant status requires a demonstrated connection between the specific terrorist plot and al Qaeda or another transnational terrorist organization. The application of the military model in the first place depends on the existence of hostilities equivalent or tantamount to an armed conflict with a nonstate armed force under the international laws of war. That is, it depends on the analogy between al Qaeda and various armed forces recognized by international law-groups which include regular armed forces, irregulars, militias, and organized resistance movements, but most especially nonstate armed factions engaged in civil war or insurrection against a state. An organized, group character of the participation in hostilities is necessary to apply principles of armed conflict. Therefore, the integrated model requires a connection to such a group, in the form of a transnational terrorist organization, for its definition of terrorist unlawful combatant status.

Thus, in the last category of persons potentially defined as terrorists, the integrated model allows only those persons who are members of a specific al Qaeda terrorist plot posing the danger of an imminent terrorist attack to be deemed terrorist unlawful combatants. Those persons are military enemies subject to military authority. All other persons in the last category remain noncombatants subject only to ordinary criminal law.

Taken together, the four categories provide the integrated model's definition of the individuals who may be held responsible as terrorists. Combining the analysis from the four categories reveals the integrated model's conclusions about which persons should be deemed military enemies, and which must be criminal defendants.

First, the great majority of individuals affiliated with al Qaeda and other transnational terrorist organizations, even the great majority of those involved in conspiracies to plan and commit particular terrorist attacks, must be treated as criminal defendants. They may be held responsible for their participation in terrorist activities, of course, to the extent they are culpable under ordinary criminal law. But they present no extraordinary factors justifying the application of military authority in dealing with them. 
Second, only a narrow range of al Qaeda members - those who have directly participated in a completed terrorist attack or those who are directly participating in a specific plot and are ready to commit an imminent attack-may be deemed military enemies. These persons are unlawful combatants and may be treated as such. They may be targeted by military force, detained as military prisoners, or prosecuted and punished in military proceedings. By their personal participation to this substantial degree in al Qaeda's activities of actually or imminently carrying out terrorist attacks, they have become combatants in an armed conflict.

The practical implementation of the integrated model is straightforward. High-level al Qaeda leaders, such as commanders and strategists, clearly are military enemies. If they are captured alive, they may be detained as military prisoners. Because such persons are responsible for directing, planning, and ordering completed terrorist attacks, they may be prosecuted for the applicable war crimes in military proceedings, as well as applicable civilian criminal charges. The same is true for the operatives involved in particular completed terrorist attacks. Operatives participating in attempted or imminent attacks likewise may be detained as military prisoners or prosecuted in military proceedings, although the lack of a completed attack means the charges will be civilian criminal offenses, not war crimes. ${ }^{372}$

All other individuals affiliated with or involved in terrorism must be treated exclusively as criminal defendants. Like other facilitators, for example, sleeper cell operatives without a specific conspiratorial agreement must be tried and punished as criminal defendants. Clandestine terrorist operatives with a specific conspiratorial objective in the planning or preparation stages also must be treated as criminal defendants. And unaffiliated terrorists who lack any connection to an

${ }^{372}$ An alleged terrorist detained under military authority as a leader or eligible operative may seek to contest the factual allegations supporting that designation. A U.S. citizen detained in military custody may pursue a writ of habeas corpus petition to compel the Government to make a substantial showing to justify military detention. See generally Benjamin J. Priester, Return of the Great Writ: Judicial Review, Due Process, and the Detention of Alleged Terrorists as Enemy Combatants, 37 RUTGERS L.J. 39 (2005) (discussing procedural rights of U.S. citizens detained as enemy combatants). Aliens detained in the United States, similarly, may file habeas challenges to indefinite detention. See Priester, supra, at 76 n.165; see also Clark v. Martinez, 543 U.S. 371, 376 (2005) (involving habeas corpus challenge to indefinite detention under immigration laws); Zadvydas v. Davis, 533 U.S. 678, 684-86 (2001) (same). Whether aliens detained in military custody abroad may file habeas petitions in U.S. courts has been a controversial question. See Boumediene v. Bush, 476 F.3d 981 (D.C. Cir. 2007) (discussing history of litigation challenging Guantanamo detentions, including Rasul v. Bush, 542 U.S. 466 (2004), the Detainee Treatment Act of 2005, Pub. L. No. 109-148, $\S 1005(\mathrm{e}), 119$ Stat. 2680 (2005), Hamdan v. Rumsfeld, 126 S. Ct. 2749 (2006), and the Military Commissions Act of 2006, Pub. L. No. 109-366, $\S 7(\mathrm{a}), 120$ Stat. 2600 (2006)). The U.S. Supreme Court's most recent decision on Guantanmo detainees was handed down in June 2008. See Boumediene v. Bush, 128 S. Ct. 2229 (2008) (holding that Guantanamo detainees possess the privilege of the writ of habeas corpus to challenge their detention). 
armed force engaged in hostilities, whether al Qaeda or another transnational terrorist organization, must be criminal defendants, as well. ${ }^{373}$

The integrated model provides a comprehensive framework for defining the threat of al Qaeda and other transnational terrorist organizations. It serves the objectives of prevention and punishment by drawing upon the insights of the criminal and military models to reconcile their shortcomings. It also balances the importance of personal conduct and group affiliation by reserving the most substantial consequences for activities dependent on direct, personal involvement, while remaining cognizant of the significant contribution to the nature of the terrorist threat posed by the particular dangers of al Qaeda as a form of organized armed force. Thus, the integrated model concludes that most individuals involved in terrorism should be treated as criminal defendants, and only the most dangerous direct participants should be deemed military enemies.

\section{E. Other Implications of the Integrated Model}

The integrated model has implications beyond defining the nature of the terrorist threat. It also provides a framework for analyzing additional aspects of the legal response to al Qaeda and other transnational terrorist organizations.

First, in addition to the substantive definitional analysis discussed above, the integrated model also has consequences for a procedural analysis of the institutions used to address the terrorist threat. Just as the integrated model resolves difficulties in defining the terrorist threat generally, it equally would apply to questions raised by the prosecution and punishment of individual alleged terrorists. For reasons similar to its restrictive authorization of military authority against individuals involved in terrorist activities, the integrated model would not authorize the adoption of diminished procedural protections or reduced regularity in proceedings against them. The criminal model's procedural requisites are significant, invoking the full array of constitutional rights applicable to all criminal defendants. ${ }^{374}$ Even

${ }^{373}$ In many cases, therefore, the important question will be whether the Government can prove the individual's membership or participation in al Qaeda or another group. See Watkin, supra note 106, at 34-44 (discussing difficulties in proving affiliation). Thus, individuals who are inspired by the global jihad movement, but who have no actual connection to any other participants therein - and accordingly have not drawn upon the coordination or resources provided by transnational terrorist organizations - are the equivalent not of al Qaeda operatives engaged in warfare, but of a handful of bandits who mount an attack on a police station. See supra note 313.

${ }^{374}$ See U.S. CONST. amends. V-VI (including, inter alia, the Jury Trial Clause, Confrontation Clause, Compulsory Process Clause, and Due Process Clause); In re Winship, 397 U.S. 358, 364 (1970) (holding that the Due Process Clause requires the Government to proves it case beyond a reasonable doubt in criminal prosecutions); see also 3 Wayne R. LaFave eT AL., Criminal Procedure at 1089-1127 (3d ed. 2000 \& Supp. 2007) (discussing the constitutional rights of criminal defendants at trial). 
in terrorism cases, these rights must be enforced. ${ }^{375}$ Similarly, the existing international laws of war also provide a high level of procedural protections when proceedings to prosecute and punish individuals are instituted, even against unlawful combatants. ${ }^{376}$ While the integrated model would allow certain terrorists to be tried in military proceedings rather than civilian courts, it would reject the denial of meaningful representation by counsel, the use of secret or classified evidence the defense is precluded from confronting or contesting, or any other substantial decrease in the procedural protections provided to accused terrorists who are put on trial in either civilian or military courts. ${ }^{377}$

Second, the integrated model suggests several opportunities for adapting and reforming federal criminal law to more carefully address the terrorist threat. Rather than stretching the outer limits of conspiracy law principles or pushing the boundaries of inchoate offense liability, facilitation offenses are better suited to confronting the group affiliation aspects of the terrorist threat. By focusing on the individual's conduct and state of mind in knowingly rendering general aid to terrorist groups, facilitation offenses strike deep at the roots of support for terrorism without requiring proof of specific involvement in particular terrorist plots. Relying on facilitation offenses in such circumstances thus ensures that culpable individuals are punished for what they have actually done, rather than

${ }^{375}$ For example, the Classified Information Procedures Act (CIPA) provides the procedures that determine how to proceed in a criminal prosecution when classified information is implicated in either the Government's or defendant's case. See 18 U.S.C. app. $3 \S \S 1-16$ (2006). In certain situations, when necessary to protect the defendant's interests, the court may order the disclosure of classified information, provide the defendant with summaries or substitutions for that information, or even dismiss the indictment. See id. $\S 6$. Similarly, the Government's refusal to allow the defendant access to potentially exculpatory national security information may violate the Compulsory Process Clause. See United States v. Moussaoui, 382 F.3d 453, 471-76 (4th Cir. 2004) (holding that denying the defendant access to three al Qaeda leaders held in military custody as enemy combatants, who potentially could provide exculpatory testimony for the defendant, violated Compulsory Process Clause), reh'g granted, United States v. Moussaoui, 365 F.3d 292 (4th Cir. 2004).

${ }^{376}$ See supra notes $137,160,181-183$, and accompanying text.

377 Some commentators have proposed the creation of special courts to handle terrorism cases. See, e.g., Jack L. Goldsmith \& Neal Katyal, Op-Ed., The Terrorists ' Court, N.Y. TIMES, July 11, 2007, at A19 (arguing for the creation of a special court to make preventive detention determinations regarding accused terrorists); Glenn Sulmasy, Op-Ed., Momentum for a National Security Court, JURIST, July 13, 2007, http://jurist.law.pitt.edu/ forumy/2007/07/momentum-for-national-security-court.php (arguing for creation of special courts to hold criminal trials of terrorists); cf. David Glazier, The "War on Terror": Criminal Law Minus or Law of War Plus?, July 13, 2007, http://natseclaw.typepad.com/ natseclaw/2007/07/national-securi.html (criticizing both proposals). The integrated model would not necessarily reject these proposals as another form of accommodation between the criminal and military models, so long as the new judicial forum retained the same stringent degree of procedural standards. 
trying to describe them as members of a broad or amorphously described "conspiracy" that does not fit the facts. This increased focus on facilitation theories of liability, however, suggests the need to enact more narrowly tailored gradations of facilitation offenses. For example, an individual who knowingly provides weapons or explosives to agents of an FTO for an undetermined future attack may warrant conviction for a more severe offense than a person who knowingly provides financial support to an FTO for general expenses. Similarly, members of a terrorist sleeper cell who intend to personally plan and carry out a terrorist attack, but currently lack any identifiable specific agreement, preparations, or objectives to constitute a conspiracy, are considerably more dangerous than persons who are willing to sacrifice nothing more to the cause than their money. Thus, just as facilitators are differently culpable than conspirators, not all facilitators are equally culpable, and the applicable facilitation offenses should reflect these different degrees of dangerousness and extent of support. Finally, although unaffiliated terrorists are not military enemies, they are a dangerous threat, and facilitating them should also be a crime. ${ }^{378}$

Third, the integrated model also suggests several possibilities for adapting and reforming the international laws of war in response to the threat of transnational terrorist organizations. The nature of the armed conflict with al Qaeda and similar groups should be addressed on its own terms, rather than seeking to make it fit the preexisting boxes of international and noninternational conflicts. Similarly, the threat of transnational terrorist organizations has revived once again the difficult and controversial questions of combatant and noncombatant status and the rules applicable to the treatment of unlawful combatants. International agreement on these issues may not be possible generally, much less in the context of terrorism, but the need for adaptation and reform is undeniable. Most notably, however, the principle of equality of belligerents should be directly confronted and soundly rejected in the context of terrorism. No matter the seeming justifiability or arguable nobility of the cause, transnational nonstate organizations waging conflict through terrorism rightly bear the condemnation of the entire international community. Unlike legally or morally ambiguous international or intrastate conflicts in which all parties have an interest in according each other mutual respect under the laws of war, terrorist groups that flout the very premises of the international laws of war should be condemned by it.

${ }^{378}$ The offense need not be coextensive with the current FTO offense in $\S 2339 \mathrm{~B}$, and might address rendering support to individual terrorists or a particular group of terrorist conspirators, rather than an organization on a government-maintained list. See supra note 95. Nonetheless, providing at least certain kinds of support (e.g., weapons or money) to persons known to be involved in terrorist acts or plans (but without sufficient information or intent to become a conspirator in any particular terrorist plot) is culpable action worthy of criminal punishment, whether the persons aided are affiliated with an FTO or instead are homegrown threats. 


\section{CONCLUSION}

The nature of the terrorist threat is not easy to define. In some ways terrorists resemble traditional criminals, albeit criminals of a particularly dangerous sort. In other ways terrorists resemble traditional combatants engaged in armed conflict with an enemy nation. But each analogy has its flaws, because the threat posed by al Qaeda and other transnational terrorist organizations is substantially different from both paradigmatic criminal activity and paradigmatic military violence.

Accordingly, the existing principles and doctrines of U.S. federal criminal law and the international laws of war cannot fully address the nature of the terrorist threat. The criminal model presents one set of laws for defining the threat of terrorism; the military model offers another. Each model, in its current form, provides opportunities for pursuing the dual objectives of preventing terrorist attacks from occurring and punishing individuals involved with planning or committing acts of terrorism or with supporting the operations of terrorist organizations.

While the criminal and military models each provide insights into the nature of the terrorist threat, each also has shortcomings in defining it. Both models have difficulty balancing the relative importance of personal conduct and group affiliation when assessing the dangerousness and culpability of individual terrorists or particular conspiracies and the broader organizations of which they are a part. Thus, neither model standing alone adequately addresses all aspects of the problem.

The solution is an integrated model combining the criminal and military models into a unified, comprehensive framework for defining the threat of al Qaeda and other transnational terrorist organizations. This integrated model identifies which terrorists - and individuals with connections to terrorists or terrorist organizations - should be treated as criminal defendants, and which should be deemed military enemies subject to military authority. It pursues the objectives of prevention and punishment by drawing upon the insights of the criminal and military models to reconcile their respective shortcomings. The integrated model also balances the importance of personal conduct and group affiliation by reserving the most substantial consequences for activities dependent on direct, personal involvement. But it also takes full account of the particular dangers that exist because of al Qaeda's nature as a form of organized armed force, and the substantial implications that holds for the nature of the terrorist threat. The integrated model concludes that most individuals involved in terrorism should be treated as criminal defendants and only the most dangerous direct participants should be deemed military enemies. In this way, the integrated model resolves the problems of the existing criminal and military models and fully addresses the threat posed by al Qaeda and other transnational terrorist organizations. 